\title{
Mind Your Step
}

the flâneur as play[write] in the play[ground] of the city

by

Nathan J Dykstra B.A.S.

A thesis submitted to the Faculty of Graduate Studies in partial fulfillment of the requirements for the degree of

\section{Master of Architecture}

M.ARCH PROFESSIONAL

School of Architecture Carleton University Ottawa, Ontario September 2008 


$\begin{array}{ll}\begin{array}{l}\text { Library and } \\ \text { Archives Canada }\end{array} & \begin{array}{l}\text { Bibliothèque et } \\ \text { Archives Canada }\end{array} \\ \begin{array}{l}\text { Published Heritage } \\ \text { Branch }\end{array} & \begin{array}{l}\text { Direction du } \\ \text { Patrimoine de l'édition }\end{array} \\ \begin{array}{l}\text { 395 Wellington Street } \\ \text { Ottawa ON K1A 0N4 } \\ \text { Canada }\end{array} & \begin{array}{l}\text { 395, rue Wellington } \\ \text { Ottawa ON K1A ON4 } \\ \text { Canada }\end{array}\end{array}$

978-0-494-44101-5

Ottawa ON K1A ON4

Canada
Your file Votre référence
ISBN:
Our file Notre reterence
ISBN:
NOTICE:

The author has granted a nonexclusive license allowing Library and Archives Canada to reproduce, publish, archive, preserve, conserve, communicate to the public by telecommunication or on the Internet, loan, distribute and sell theses worldwide, for commercial or noncommercial purposes, in microform, paper, electronic and/or any other formats.

The author retains copyright ownership and moral rights in this thesis. Neither the thesis nor substantial extracts from it may be printed or otherwise reproduced without the author's permission.
AVIS:

L'auteur a accordé une licence non exclusive permettant à la Bibliothèque et Archives Canada de reproduire, publier, archiver, sauvegarder, conserver, transmettre au public par télécommunication ou par l'Internet, prêter, distribuer et vendre des thèses partout dans le monde, à des fins commerciales ou autres, sur support microforme, papier, électronique et/ou autres formats.

L'auteur conserve la propriété du droit d'auteur et des droits moraux qui protège cette thèse. $\mathrm{Ni}$ la thèse ni des extraits substantiels de celle-ci ne doivent être imprimés ou autrement reproduits sans son autorisation.
In compliance with the Canadian Privacy Act some supporting forms may have been removed from this thesis.

While these forms may be included in the document page count, their removal does not represent any loss of content from the thesis.
Conformément à la loi canadienne sur la protection de la vie privée, quelques formulaires secondaires ont été enlevés de cette thèse.

Bien que ces formulaires aient inclus dans la pagination, i) n'y aura aucun contenu manquant. 

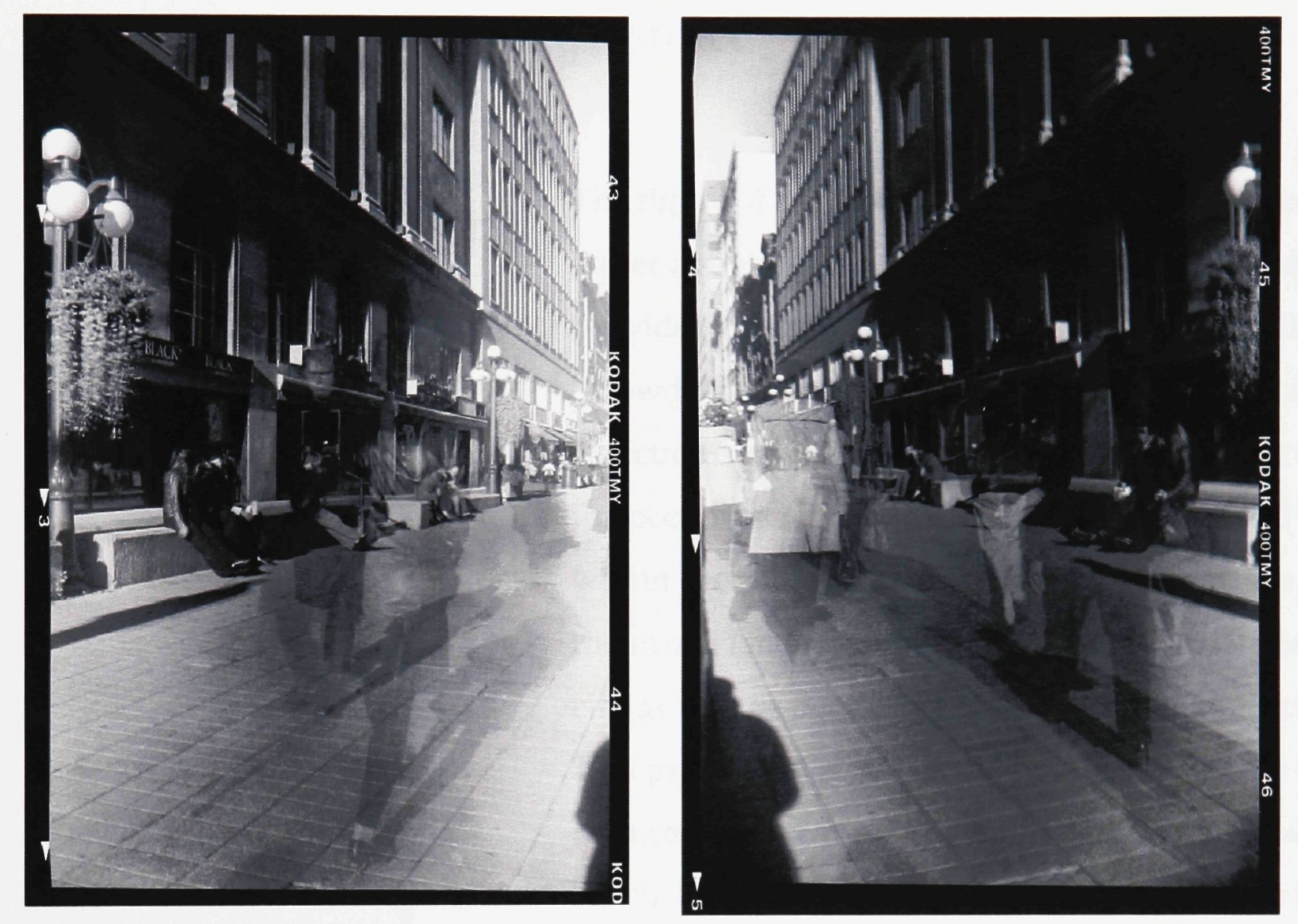

Mind Your Step

the flâneur as play[write] in the play[ground] of the city 


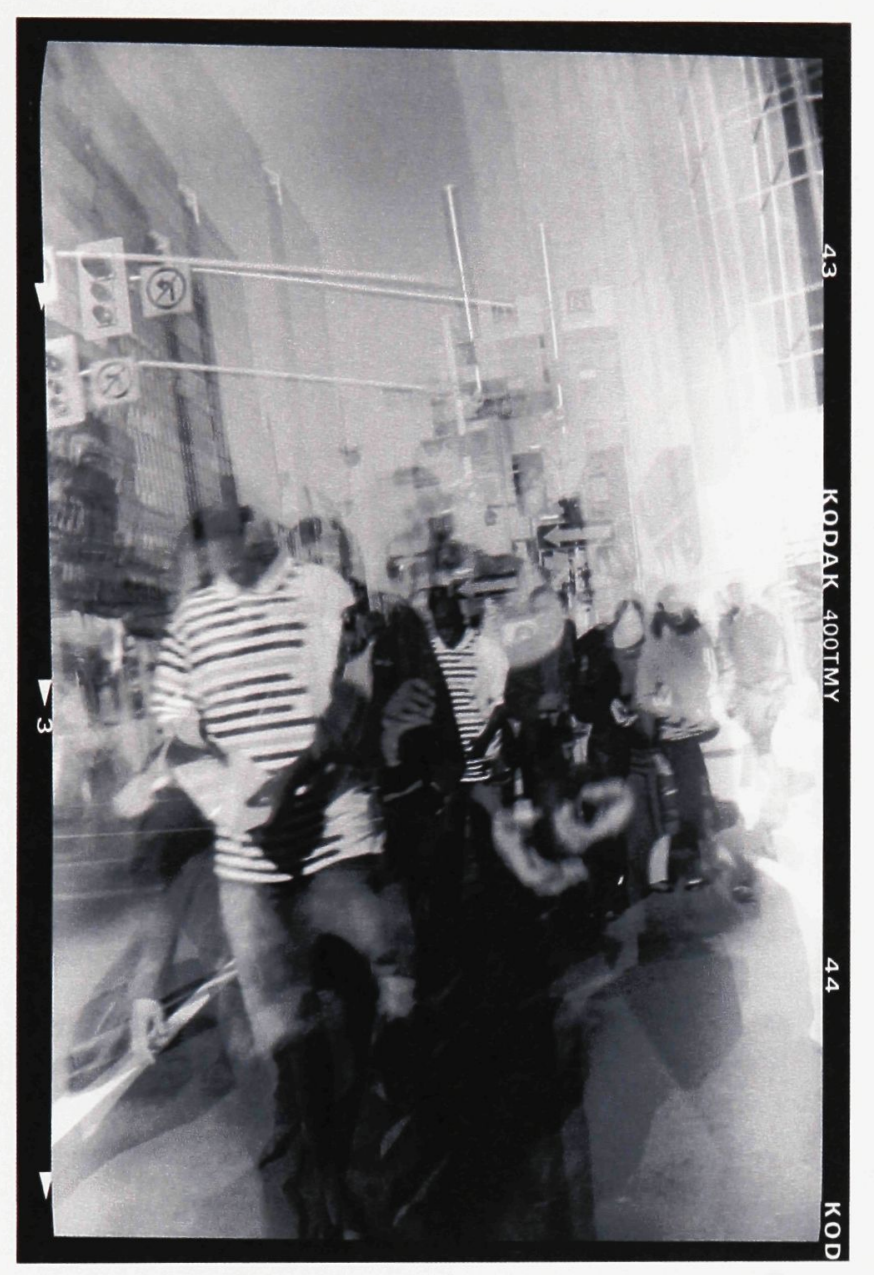

Crowd by Author

\section{Abstract}

The figure of the flaneur as a peripatetic philosopher of the street as defined by Charles Baudelaire and Walter Benjamin provides an analytical tool to distil from the collective, or "crowd" the current state of modernity and decipher the direction society is moving towards in the future. By observing the occupants of the city and how they respond to each other within the context of the built environment, the flâneur reads the urban landscape gaining both practical understanding of the city as well as poetic inspiration from its characters and events. This practice is of relevance to architects in the design of civic architecture for the architect to better understand the city and his client: the crowd. This thesis proposes that the flâneur become architect is a choreographer/play[write] of the spaces he designs responding to the theatricality and spontaneity of the urban theatre. 
To the city with its many twists and turns that provided so much inspiration, to my family that supported me when I got lost, and to my advisor, Stephen Fai, who helped me find my way 


\section{Contents}

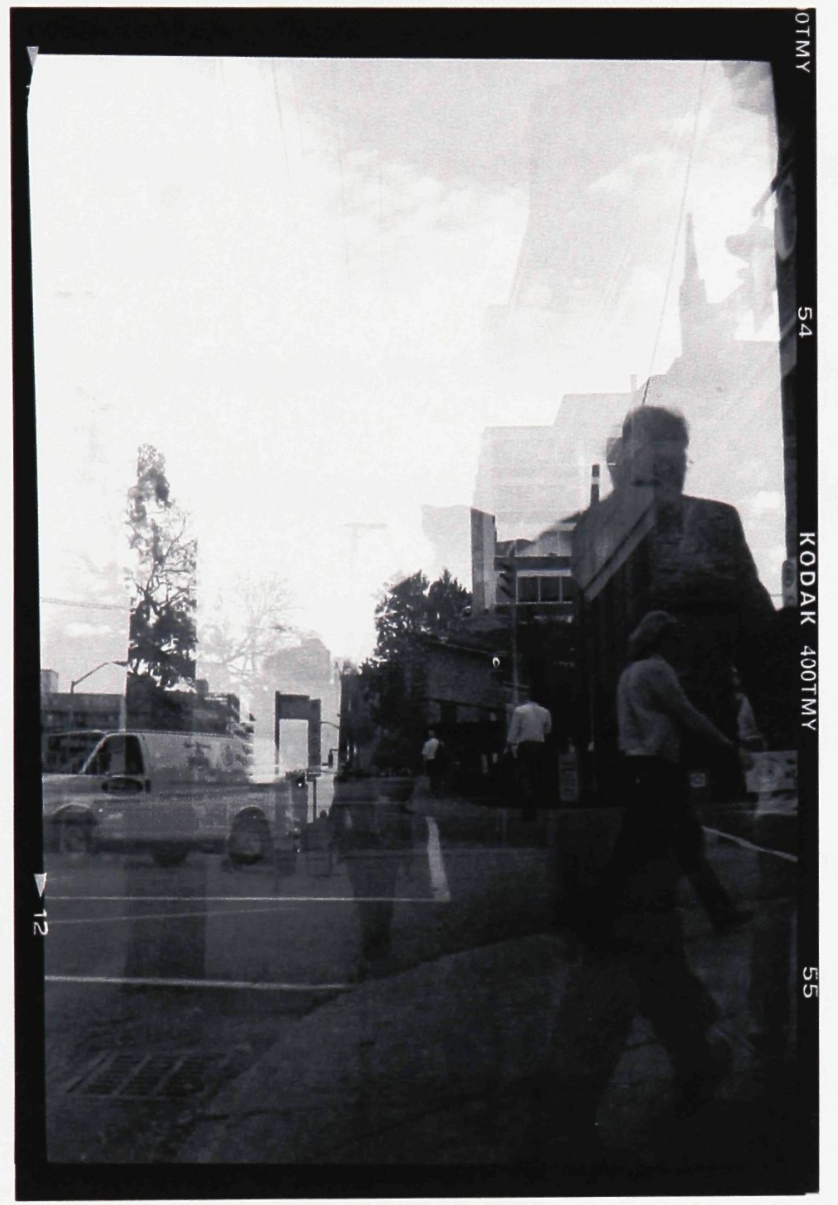

What Lies Beyond the Corner by Author
Introduction $\quad 1$

Crowds 5

The Experience of the Street 6

An Afternoon at the Market [Graphic Story] 9

Who is the Flâneur? 32

Flâneur as Consumer $\quad 42$

Flânerie Expropriated $\quad 45$

The Flâneur as travelling player/play[write] 47

Flânerie as an Analytic Tool $\quad 49$

My Flânerie...

Conclusion $\quad 64$

Appendix [Project: Arena of the Flâneur] 67

Bibliography 83 


\section{List of Illustrations}

fig 1 "Space", Will Eisner,

Eisner, Will. “City People Notebook." New York: Life in the Big City (New York: W.W. Norton \& Company Ltd., 2006) 269

fig 2 "Ramadhan in the Mosque of Top Hane, Constantinople", Constantin Guys

Baudelaire, Charles. The Painter of Modern Life. (London: Phaidon Press, 1964) 9

fig 3 "Life of a Swap Box", Simon Milligan

Milligan, Simon. Flickr. 16 August 2008 <http://flickr.com/photos/39212395@N00/sets/72057594134688097/>

[used under creative commons license]

fig 4 Lansdowne Park c. 1910; City of Ottawa Archives, Phil Dunning Collection, CA-007687

fig 5 Central Canada Exhibition, Lansdowne Park; City of Ottawa Archives, CA-018766

All other images by author. Copyright Nathan Dykstra 2008 


\section{Introduction}

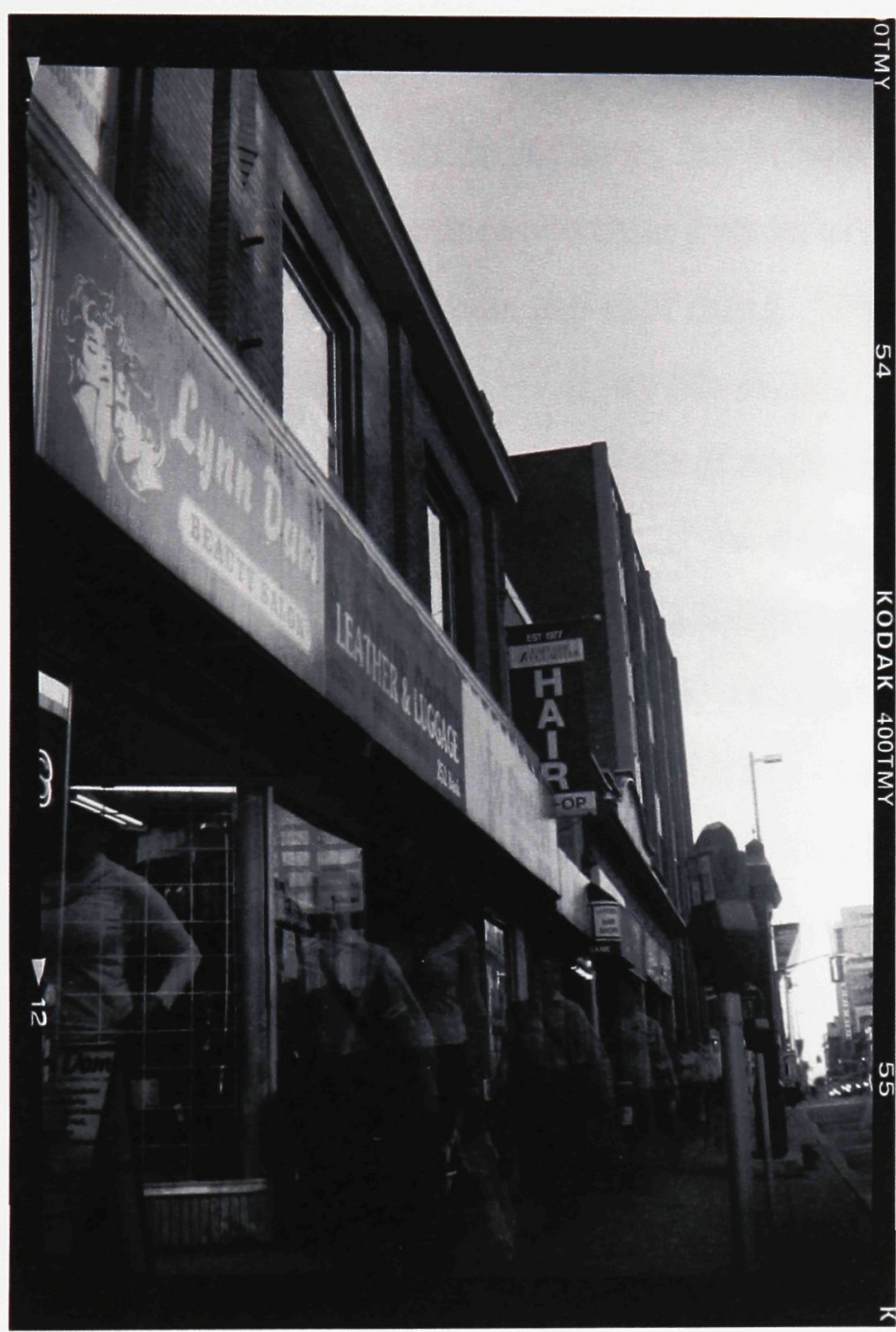

A Stroll Down Bank Street by Author
"Moving elements in a city, and in particular the people and their activities, are as important as the stationary physical parts. We are not simply observers of this spectacle, but are ourselves a part of it, on the stage with the other participants. Most often our perception of the city is not sustained, but rather partial,

fragmentary, mixed with other concerns. Nearly every sense is in operation, and the image is the composite of them all." 1

City Streets are some of the very few democratic spaces left; they bring together characters of all backgrounds and types into a socially intimate stage set that is the street. The street is the playground of the city; home to joyful celebrations, political protests, and mournful processions. As lowly and random as casual street contact may appear, it is the seed from which the city life and community grows. These spontaneous human interactions and events of city life that revolutionists and avantgardists have understood for centuries as the "real life" of the city make the street an ideal laboratory from which to study how people respond to each other within the context of the built environment. The street is in essence the living room of the 
collective community; what better way to understand someone than by studying how they live in that room and the personal artifacts that they keep there: the same can be said about a culture and its streets.

Will Eisner, known to many as the father of the graphic novel, spent his days wandering the streets of New York City. To Eisner, cities were more than just an accumulation of large buildings, populations and acreage; the city as viewed by its inhabitants was the real thing. "The true picture is in the crevices on its floors and around the smaller pieces of its architecture where daily life swirls." 2 Eisner dedicated his life as an observer of people and composed his graphic novels based upon real events of multifaceted metropolitan life. In his City People Notebook, Eisner himself is visible as a cameo in many of his sketches: drawing, observing, and moving through the city. In the introduction, Eisner equates life in a big city to existing in a jungle; one must become a creature of their own environment responding to rhythms and choreography of street life as arcane survival skills necessary to navigate through the concrete labyrinth. Four main environmental factors that Eisner observed which characterised the city were: time, smell, rhythm, and space. Time in the city has a particular cadence affected by threads of brief events grounded within the cyclical time of the street. The street has a much different feeling at noon hour than in the evening, which is completely different than at three o'clock in the morning: characters change, shops open and close, and something that seems eternally undulating becomes almost still, lifeless, and uneasy. Smell is the symphony of emissions from copious enterprises. Rhythm is the element of speed which prescribes how dwellers must negotiate movement through space which is limited by the living area left by obstacles in the concrete maze. ${ }^{3}$ 


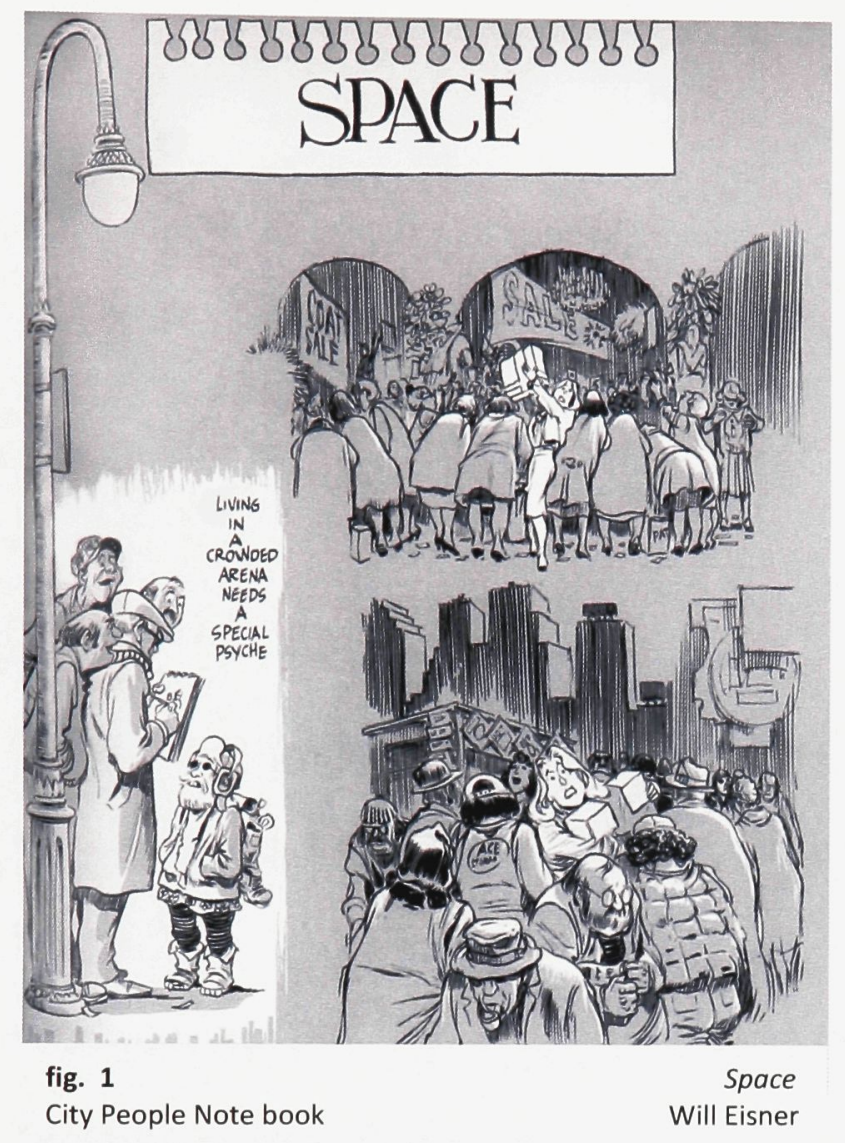

Unlike many other graphic novelists who take a very cinematic approach to their work, Eisner takes a theatrical approach, looking to solidify a connection between his work and the reader. His focus is on the drama and intimacy of everyday metropolis living; live, shared experience that anyone can relate to regardless of age, race, or gender. ${ }^{4}$ The subtle emotions of a businessman briefly pausing from his hurried, self absorbed gait to pick up a lost child's ragdoll off the sidewalk, look around for the missing owner, seeing no one, sets it on a stoop and continues on his journey; or the visceral experience of discomfort of being alone on an empty street are examples of the shared experience that Eisner portrays. In Eisner's opinion, the experience of the city is best depicted in the form of the graphic novel; "the big city lends itself to the comics story, the comic book is the medium, it is a place of great adventure. Theatre. A drama in every window. Millions of windows." 5

Like the figures of Charles Baudelaire and Walter Benjamin who observed the morphology of Paris under the new gas lamps and commercial arcades that were specific to their time, Eisner found himself in the three dimensional labyrinth of New York City, a further adaptation of the urban morphology with its skyscrapers and hurried and bustling characters. Eisner is in essence a flâneur of the $20^{\text {th }}$ century, who observed the survival skills and subtle personality changes necessary to endure in this new habitat. City People Notebook became an archaeological study of the city and its people and my introduction to the concept of the flâneur that took me on a flânerie through time and space. 


\section{Notes}

${ }^{1}$ Kevin Lynch, The Image of the City (Cambridge, Massachusetts: MIT Press, 1960) 2

${ }^{2}$ Will Eisner, New York: Life in the Big City (New York: W.W. Norton \& Company Ltd., 2006) 3

${ }^{3}$ Eisner 224

${ }^{4}$ Charles Brownstein, Eisner/Miller(Milwaukie, Oregon: Dark Horse Books, 2005) 88

${ }^{5}$ Brownstein, Eisner/Miller 256 


\section{Crowds}

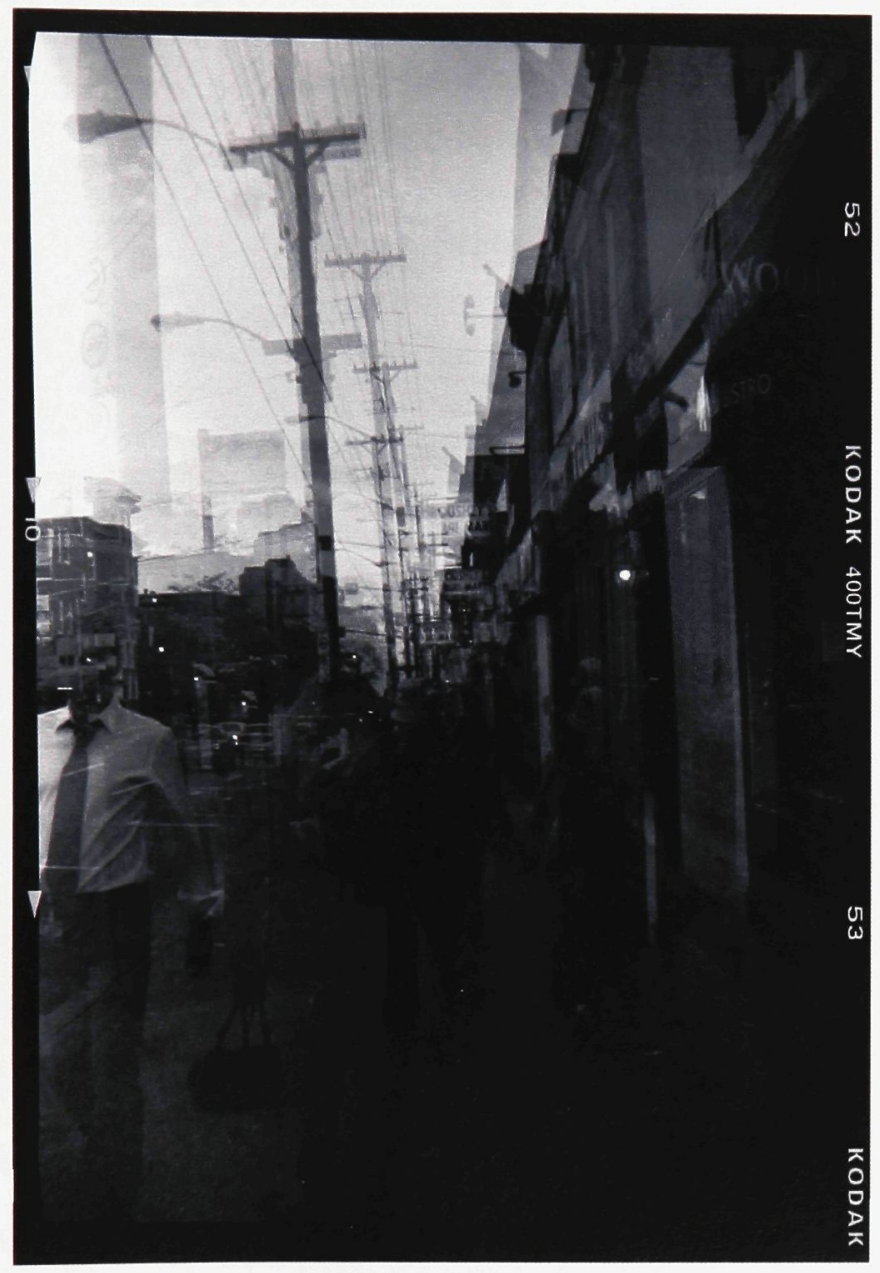

Colportage of Elgin by Author
It is not given to every man to take a bath of the multitude; enjoying a crowd is an art; and only he can relish a debauch of vitality at the expense of the human species, on whom, in his cradle, a fairy has bestowed the love of masks and masquerading, the hate of home, and the passion for roaming.

Multitude, solitude: identical terms, and interchangeable by the active and fertile poet. The man who is unable to people his solitude is equally unable to be alone in a bustling crowd.

The poet enjoys the incomparable privilege of being able to be himself or someone else, as he chooses. Like those wandering souls who go looking for a body, he enters as he likes into each man's personality. For him everything is vacant; and if certain places seem closed to him, it is only because in his eyes they aren't worth visiting

The solitary and thoughtful stroller finds singular intoxication in this universal communion. The man who loves to lose himself in a crowd enjoys feverish delights that the egotist locked up in himself as in a box, and the slothful man like a mollusk in his shell, will be eternally deprived of. He adopts as his own all the occupations, all the joys and all the sorrows that chance offers.

What men call love is a very small, restricted, feeble thing compared with this ineffable orgy, this divine prostitution of the soul giving itself entire, all its poetry and all its charity, to the unexpected as it comes along, to the stranger as it passes.

It is a good thing sometimes to teach to the fortunate of this world, if only to humble for an instant their foolish pride, that there are higher joys than theirs, finer and more uncircumscribed. The founders of colonies, shepherds of peoples, missionary priests exiled to the ends of the earth, doubtlessly know something of this mysterious drunkenness; and in the midst of the vast family created by their genius, they most often laugh at those who pity them because of their troubled fortunes and chaste lives. 


\title{
The Experience of the Street
}

\begin{abstract}
"Streets are the dwelling places of the collective. The collective is an eternally unquiet, eternally agitated being that -in the space between the building fronts-experiences, learns, understands, and invents as much as individuals do within the privacy of their own four walls. For this collective, glossy enamelled shop signs are a wall decoration as good as, if not better than, and oil painting in the drawing room of the bourgeois; walls with their "Post No Bills" are its writing desk, newspaper stands its libraries, mailboxes its bronze busts, benches its bedroom furniture, and the cafe terrace is the balcony from which it looks down on its household" -Walter Benjamin ${ }^{2}$
\end{abstract}

It was Leon Baptista Alberti who first equated the city to a house, but it was Walter Benjamin in his infamous Passagen-Werk (Arcades Project) who took the idea to a new level. This "eternally agitated being" that Benjamin wrote about is what gives streets their quality. It is not so much the architecture that abuts the street or the surface of the street itself, but the people contained there and the markings that they leave behind which becomes of interest to the flâneur. Italo Calvino wrote in his Invisible Cities, that the street absorbs history like a sponge, and contains it like the lines in the palm of the hand. Etchings, markings, and footsteps are evidence of the community that inhabits them, each one tells a different story. Calvino also stated that describing the physical qualities of a city would be the same as telling nothing, as a city exists as a dialectic between the "measurements of its space and the events of its past." 3 The street should tell us of our past and give clues to where we are moving towards in the future. Like a detective the flâneur reads these clues to understand the current state of modernity of the city, and to generate poetic inspiration. The most heterogeneous sequential elements coexist in the city: 
"If we step from an eighteenth-century house into one from the sixteenth century, we tumble down the slope of time. Right next door stands a gothic church, and we sink to the depths. A few steps farther, we are in a street from out of the early years of Bismarck's rule ..., and once again climbing the mountain of time. Whoever sets foot in a city feels caught up in a web of dreams, where the most remote past is linked to the events of today. One house allies with another, no matter what period they come from, and a street is born. And then insofar as this street, which may go back to the age of Goethe, runs into another, which may date from the Wilhelmine years, the district emerges... The climactic points of the city are its squares: here, from every direction, converge not only numerous streets but all the streams of their history. No sooner have they flowed in, than they are contained; the edges of the square serve as quays, so that already the outward form of the square provides information about the history that was played upon it." 4

City streets are a phantasmagoria of events caused by the interpenetration of characters, interrelation of program, and the interfusion of history and time. Walter Benjamin names the phenomenon of perceiving all the events to be occurring simultaneously, or the "collapsing of moments" as the colportage phenomenon of space [das

Kolportagephänomen des Raumes]. Benjamin links this phenomenon on one hand to $19^{\text {th }}$ century painting and on the other the photomontage practices of the 1920s and 1930s. Montage derives itself as a literal representation of this phenomenon with the potential to both formalize and materialize aspects of the experience. ${ }^{5}$ Montage or the collapsing of moments into a single image is the closest way of representing the experience of the street next to videography and is the flâneur's fundamental experience. Odilon Redon who learned this technique from Da Vinci wrote, "The sense of mystery comes from remaining always in the equivocal, with double and triple perspectives, or inklings of perspective (images within images) - forms that take shape and come into being according to the state of mind of the spectator." 6 


\section{Notes}

${ }^{1}$ Charles Baudelaire, Paris Spleen. trans. Louis Varnese (New York: New Directions Publishing, 1970) $20-21$

${ }^{2}$ Walter Benjamin, The Arcades Project. trans. Howard and Kevin McLaughlin Eiland (Cambridge: Belknap Press, 1999) 423

${ }^{3}$ Italo Calvino, Invisible Cities. (London: Random House, 1972) 11

${ }^{4}$ qtd. in: Benjamin, The Arcades Project 435

Originally cited: Ferdinand Lion, Geschichte Biologisch Gesehen (Zurich and Leipzig: 1935) 125-126

${ }^{5}$ Brigid Doherty, "'The Colportage Phenomenon of Space' and the place of Montage in the Arcades Project." Hannsen, Beatrice. Walter Benjamin and the Arcades Project. (London: Coninuum International Publishing, 2006) 158

${ }^{6}$ qtd. in: Benjamin, The Arcades Project 429

Originally cited: Raymond Escholier, "Artiste”, Arts et Métiers Graphiques, No.47 (June 1, 1935) p.7 


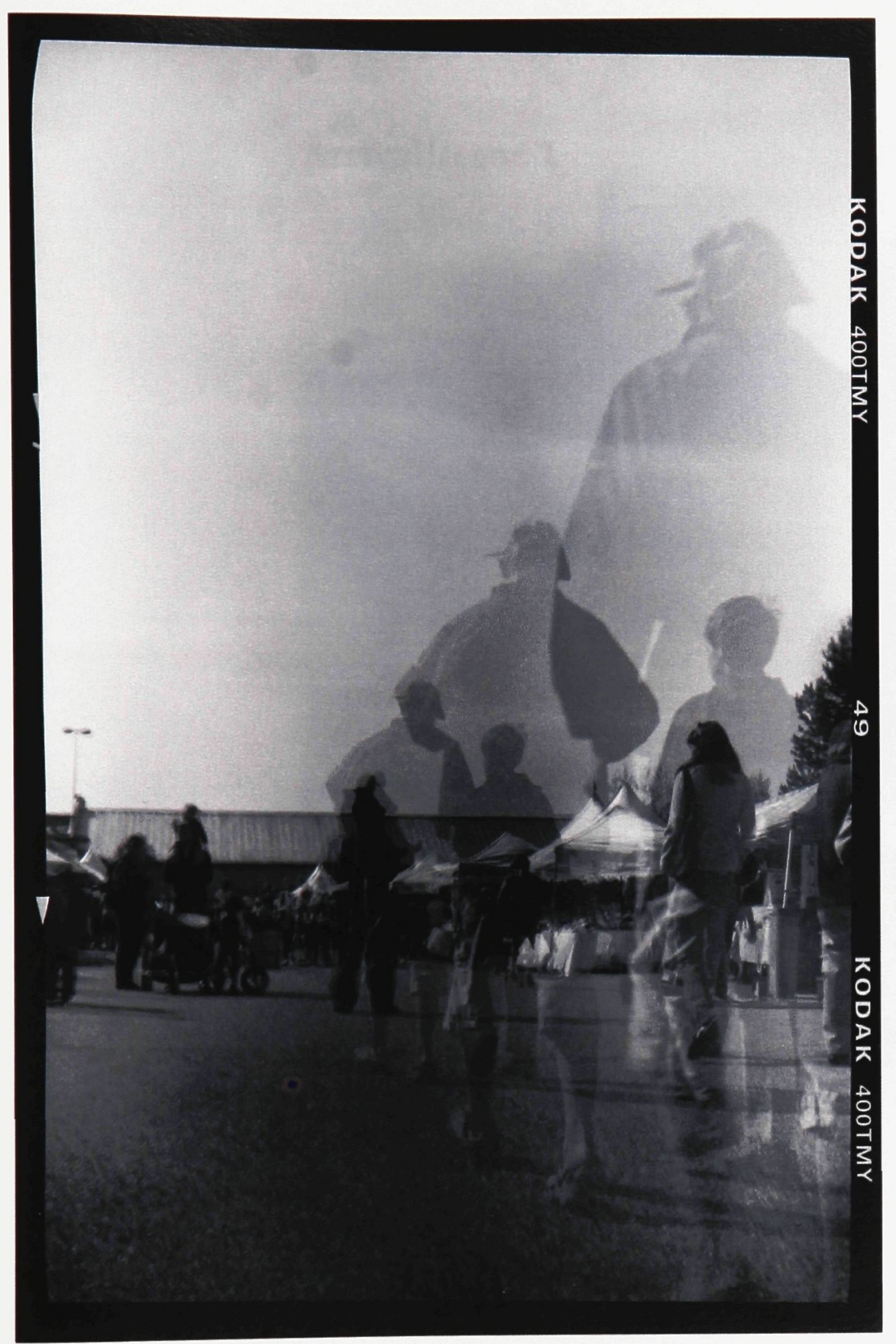

An Afternoon at the Market by Author

\section{An Afternoon at the Market}

The flâneur is a secret detective of the spontaneous spectacles of street life. Everyday occurrences, events, and interactions contained within the public realm become inspiration to the flâneur. The sights that he witnesses in collaboration with his active imagination spawn literary, artistic, or theatrical productions.

The following graphic story is of an unnamed flâneur's afternoon visit to the proposed new Ottawa Farmer's Market. The events that he witnesses and the architectural stage that he inhabits is an architectural interpretation of real flânerie based experience and events encountered throughout the streets of the greater city of Ottawa. 


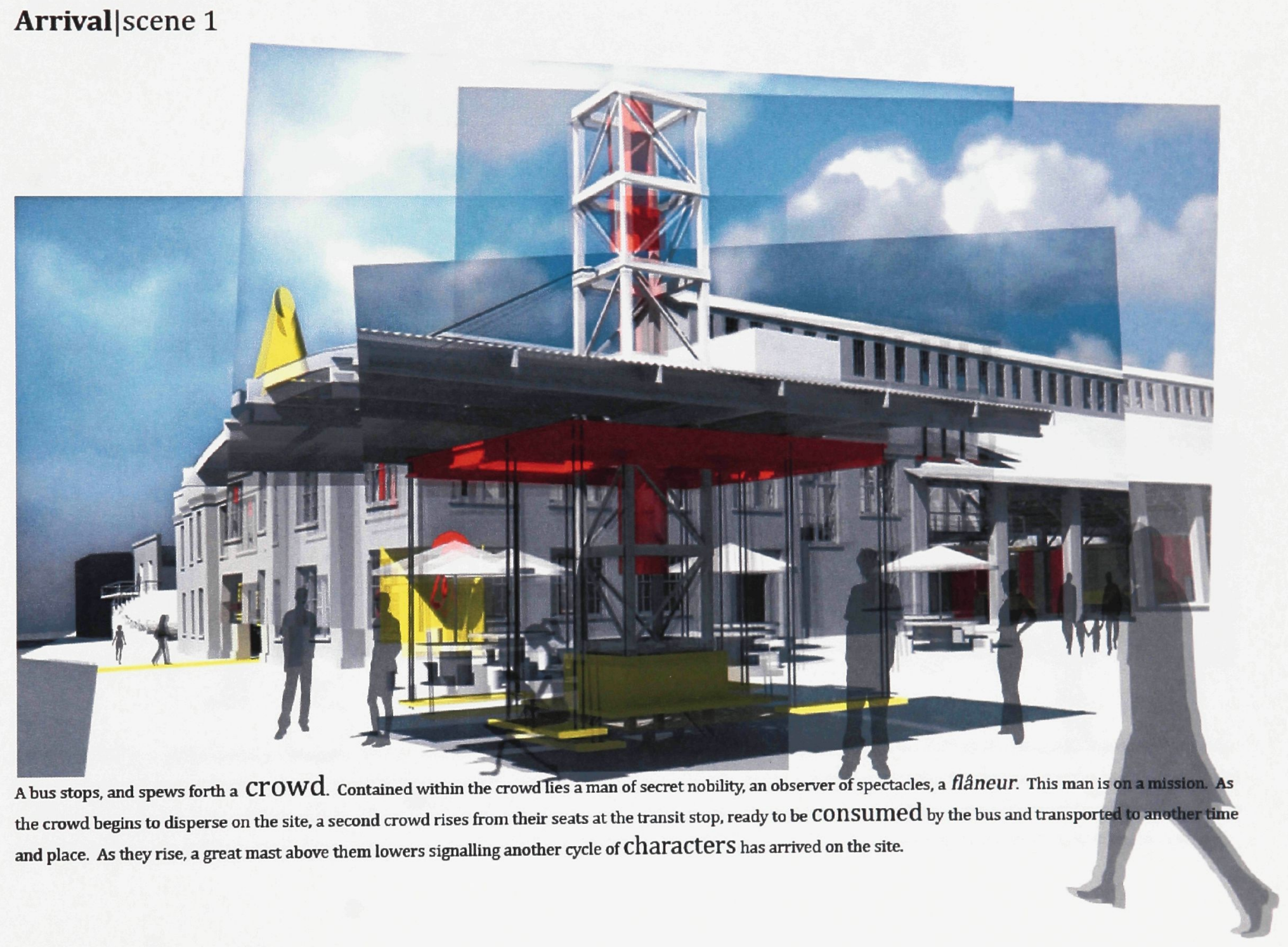




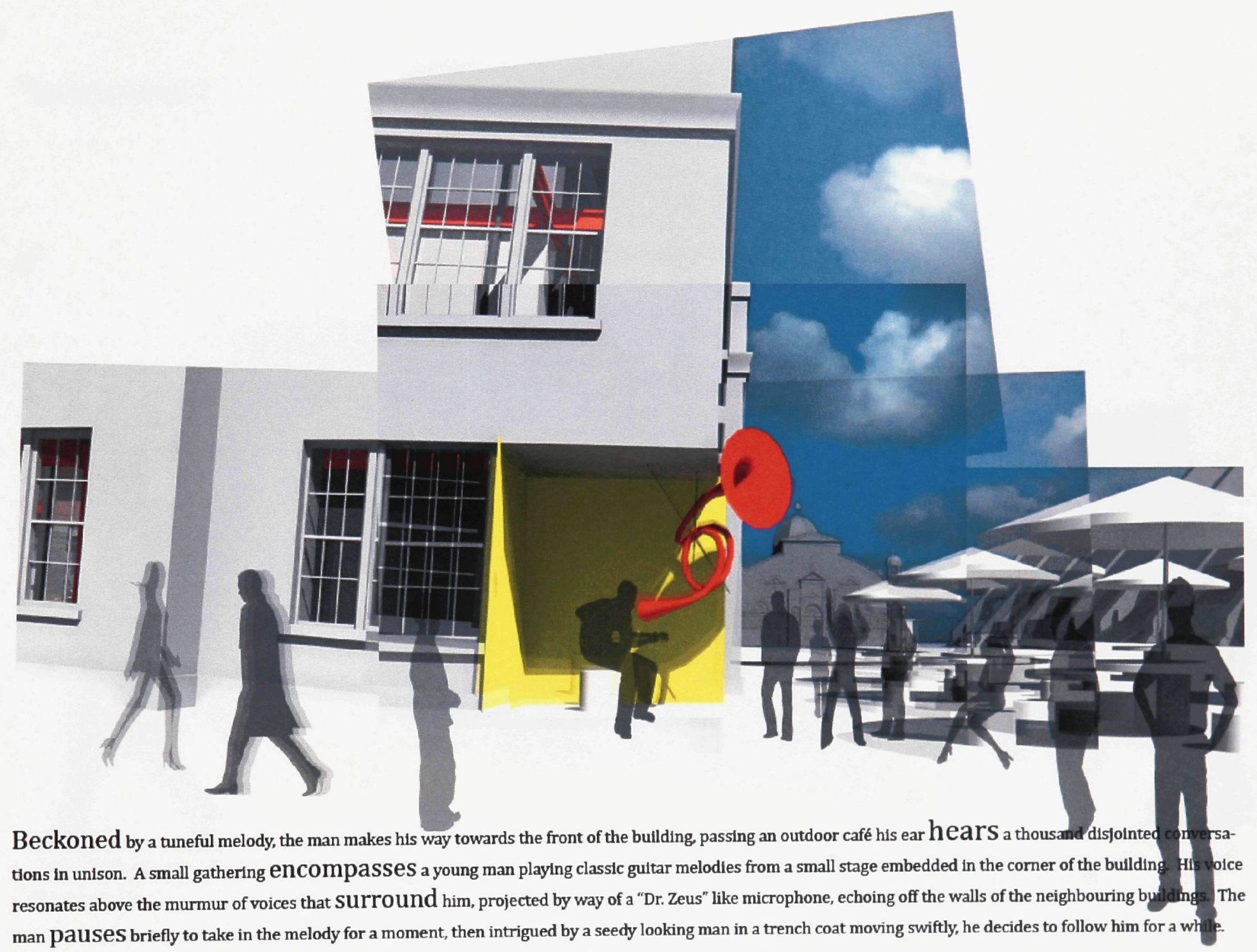




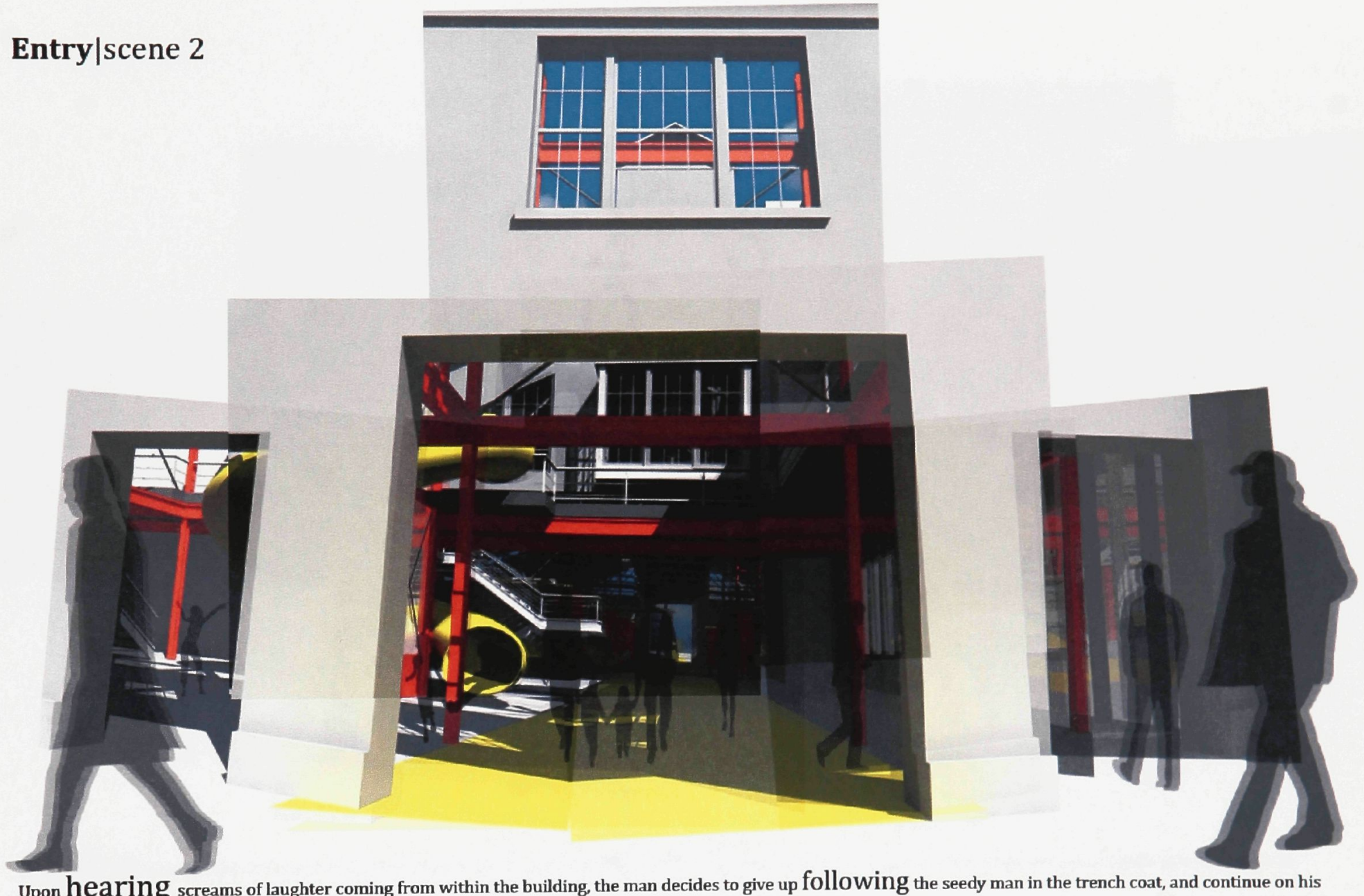

Upon hearing screams of laughter coming from within the building, the man decides to give up following the seedy man in the trench coat, and continue on his journey inside. 


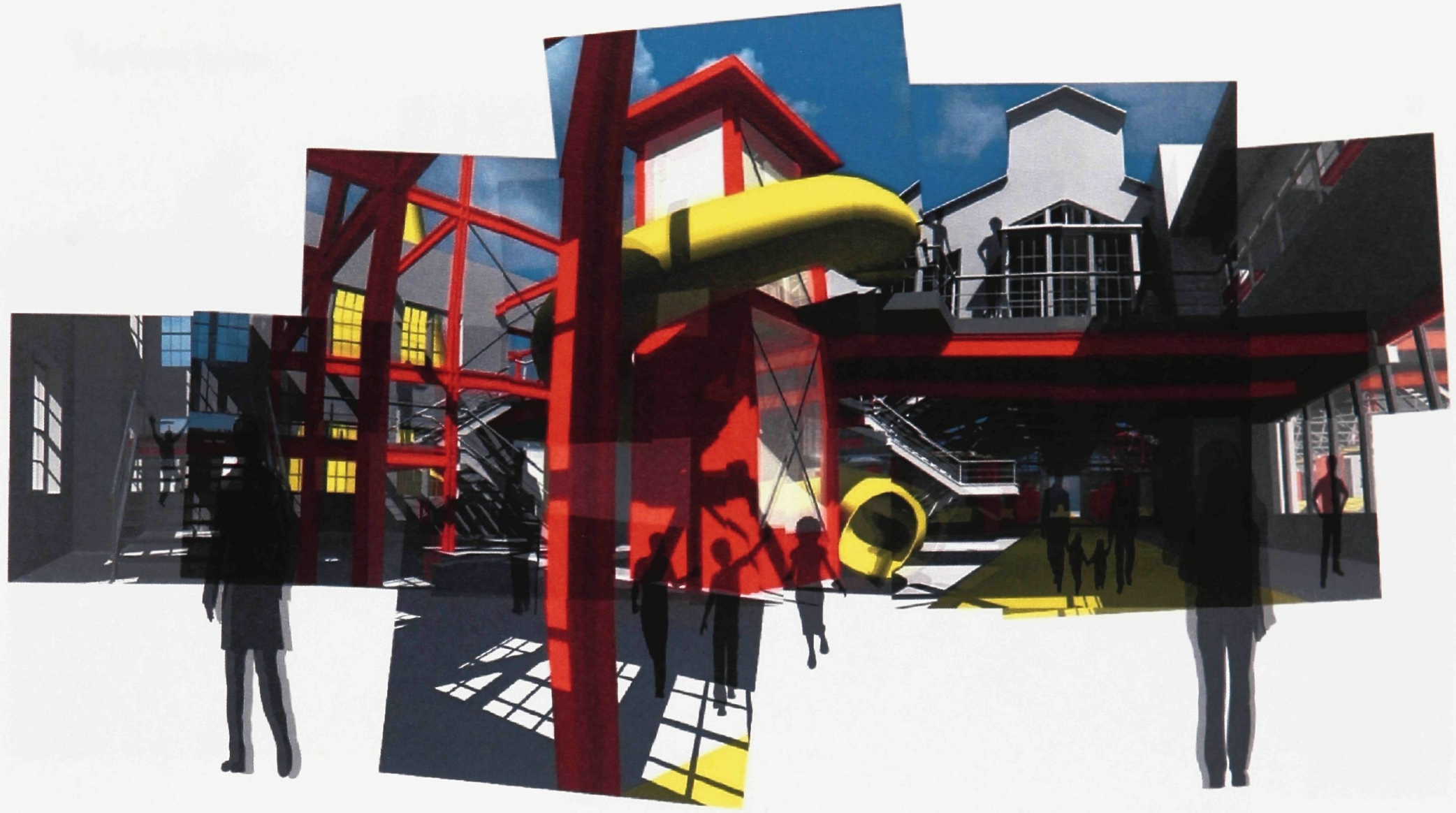

Passing through the old brick walls etched with time, he is confronted by a spiral slide with an unrelenting stream of children bursting forth. 


\section{Market| Scene 3}

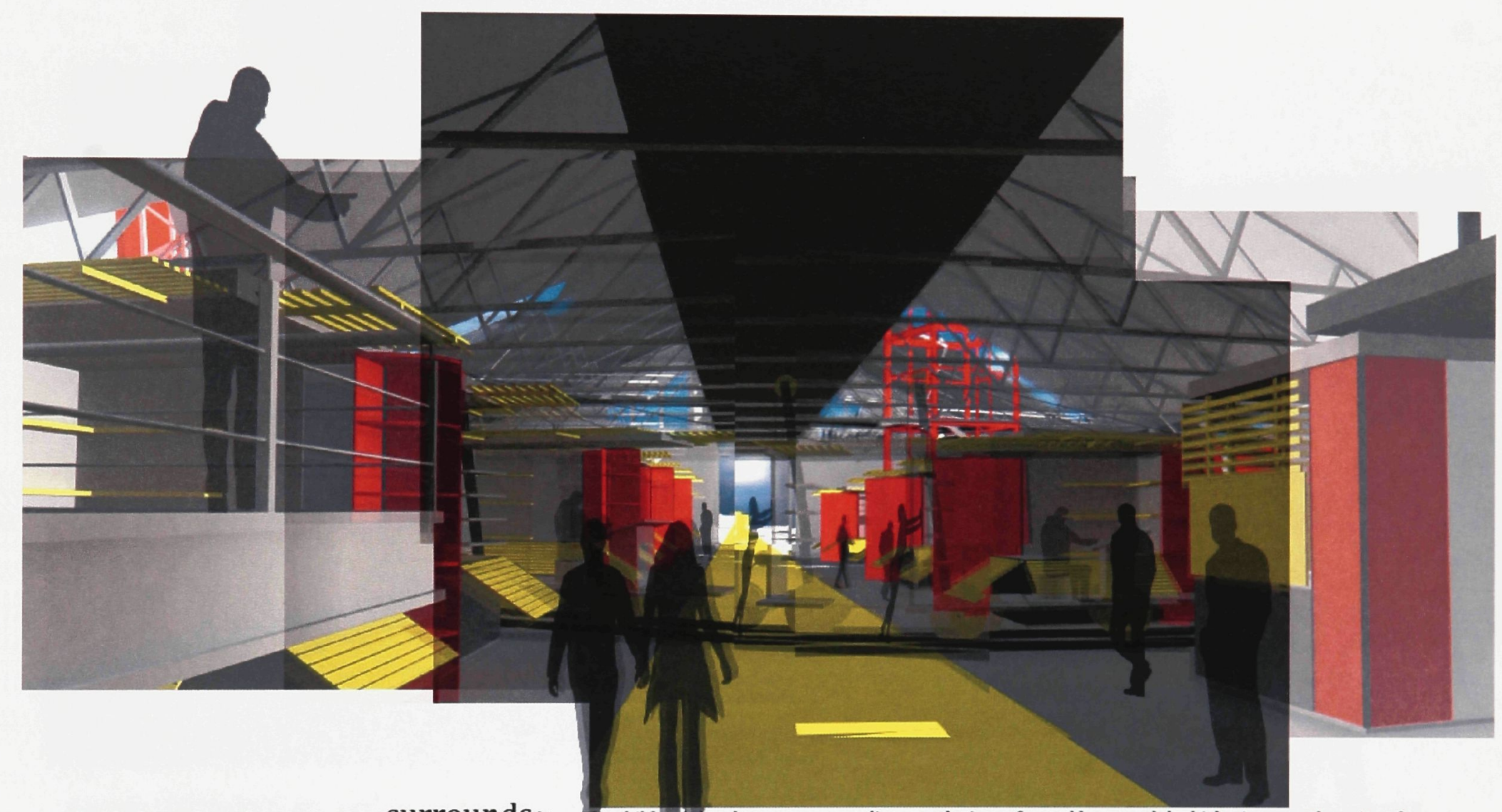

Inside the market, a frenzy of activity Surrounds him. The children's laughter now seems distant as he is confronted by two adults bickering over the price of cabbage. The first man believes that cabbage prices should be cheaper while the vendor argues that with today's commodity and input prices, he can barely make a living. "Get out of the way!" someone yells, the man jumps back, just narrowly escaping getting his toe run over as a small group of people push a cart along a track through the market. On the cart sits a desk that is barely discernable under a stack of scrawled papers. At the back of the cart, a book shelf and a book entitled Paris Spleen by Charles Baudelaire are noticed in the quick moment of passing. Once it is again safe to cross, the man continues on his journey, deeper into the bowels of the market. 


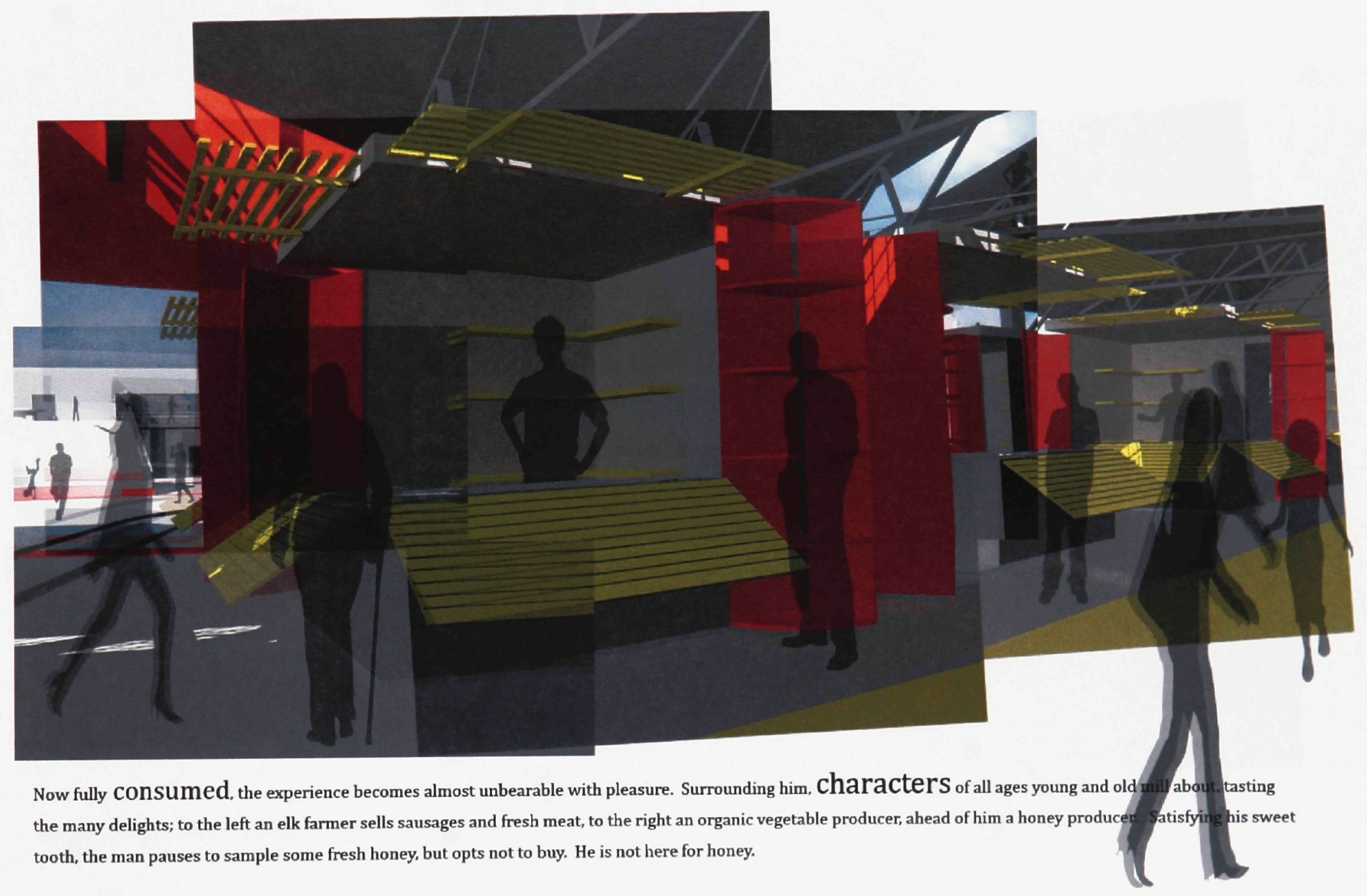




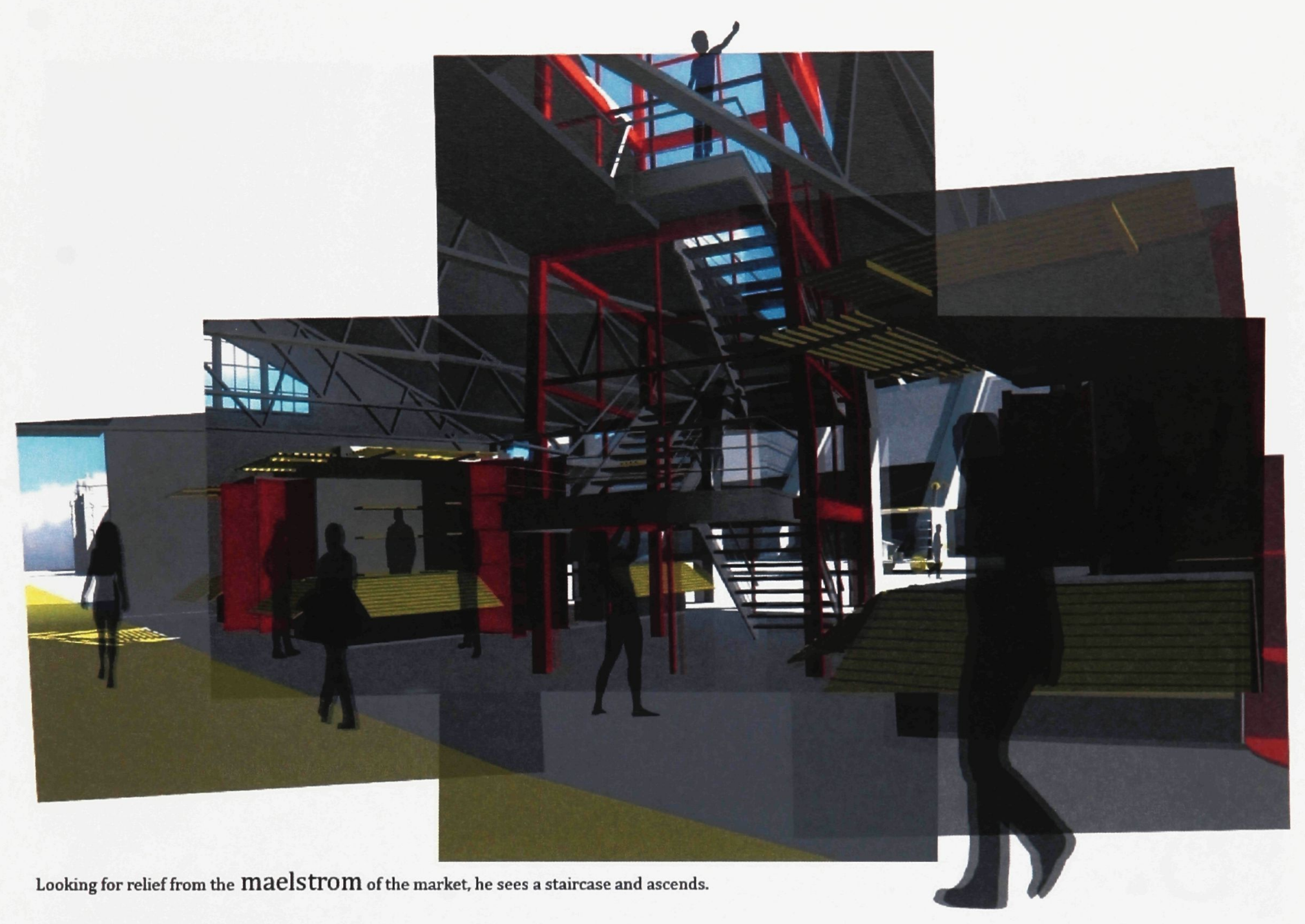




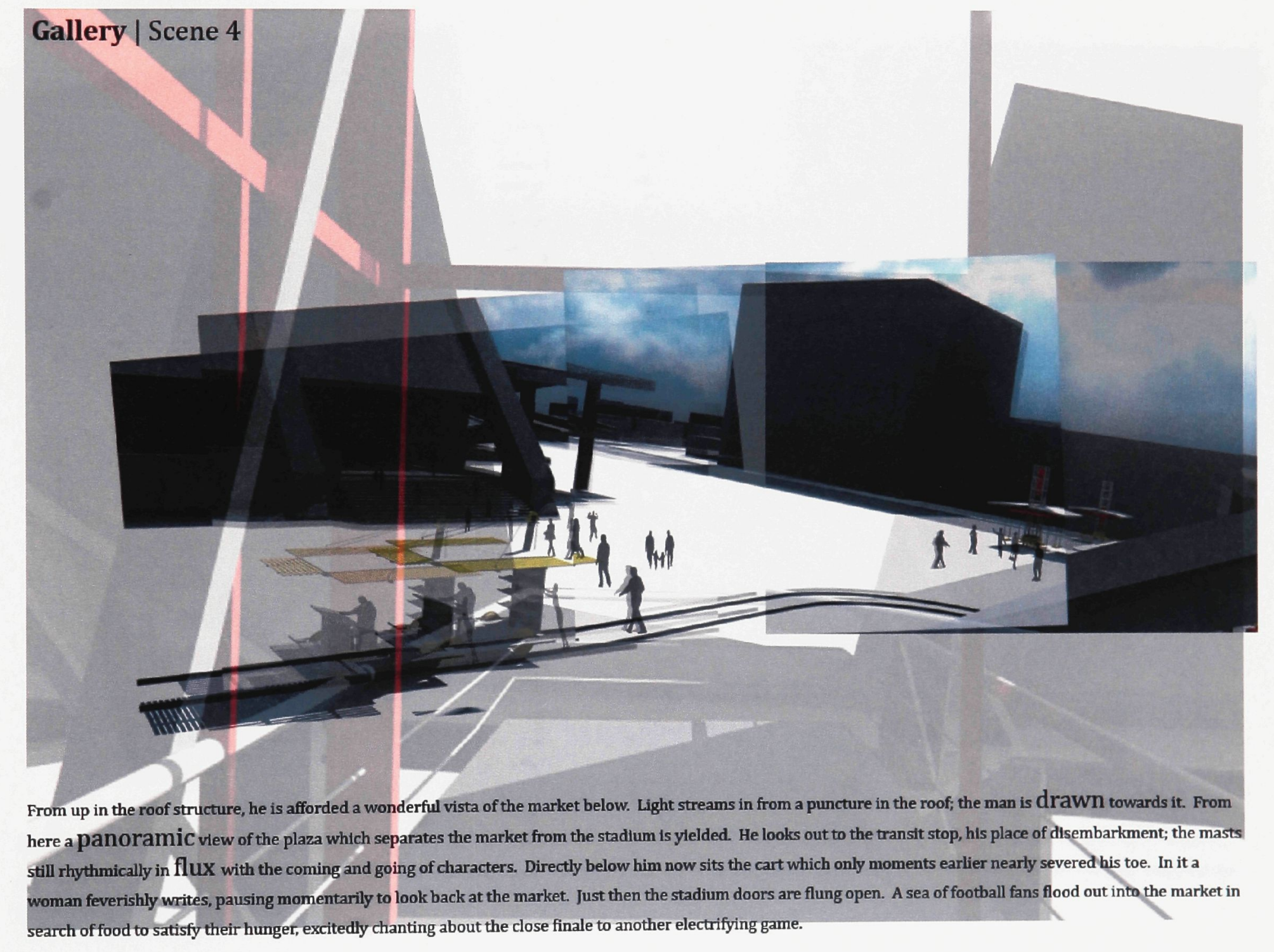




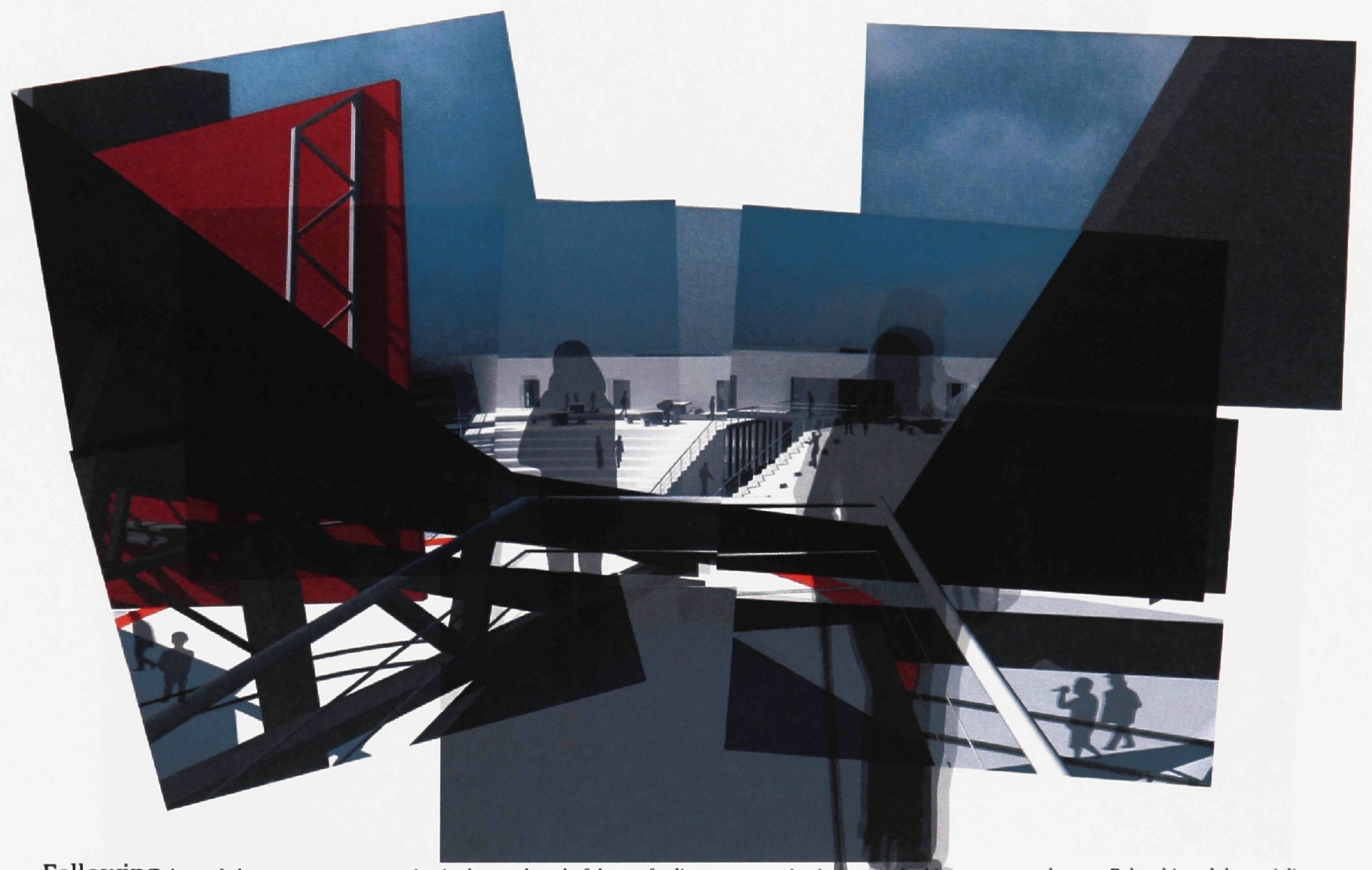

Following the path, he emerges at an opening in the north end of the roof, adjacent to a projection screetulooking out over a theatre. Below him adults socialize, families picnic, and children dash around in a blur; their traces persisting for a moment in memory. As he steps up to the edge, he feels an enormous weight of discomfort as he is exhibited for the world to see. 


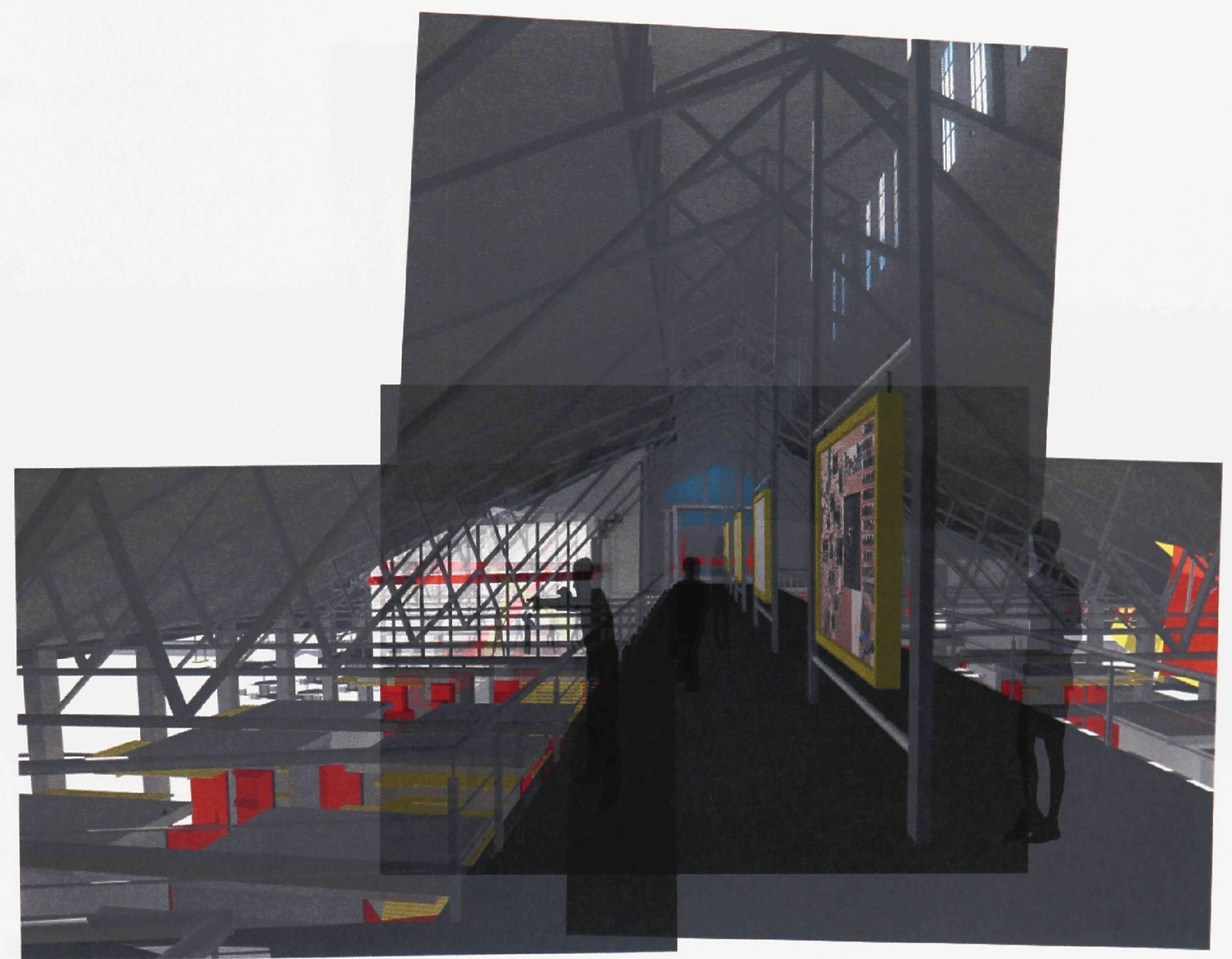

The man casually makes his way back to the shelter beneath the roof structure, pausing to peruse the random artifacts on display, he briefly reads about a street installation artist by the name "Elmaks," and continues on his journey. As he makes his way back towards the front of the market, he is enticed by the pulse of bass music felt in his chest which intensifies with each passing Step. Through large glass windows, bright coloured light streams, interrupted intermittently by the silhouettes of figures dancing inside. 


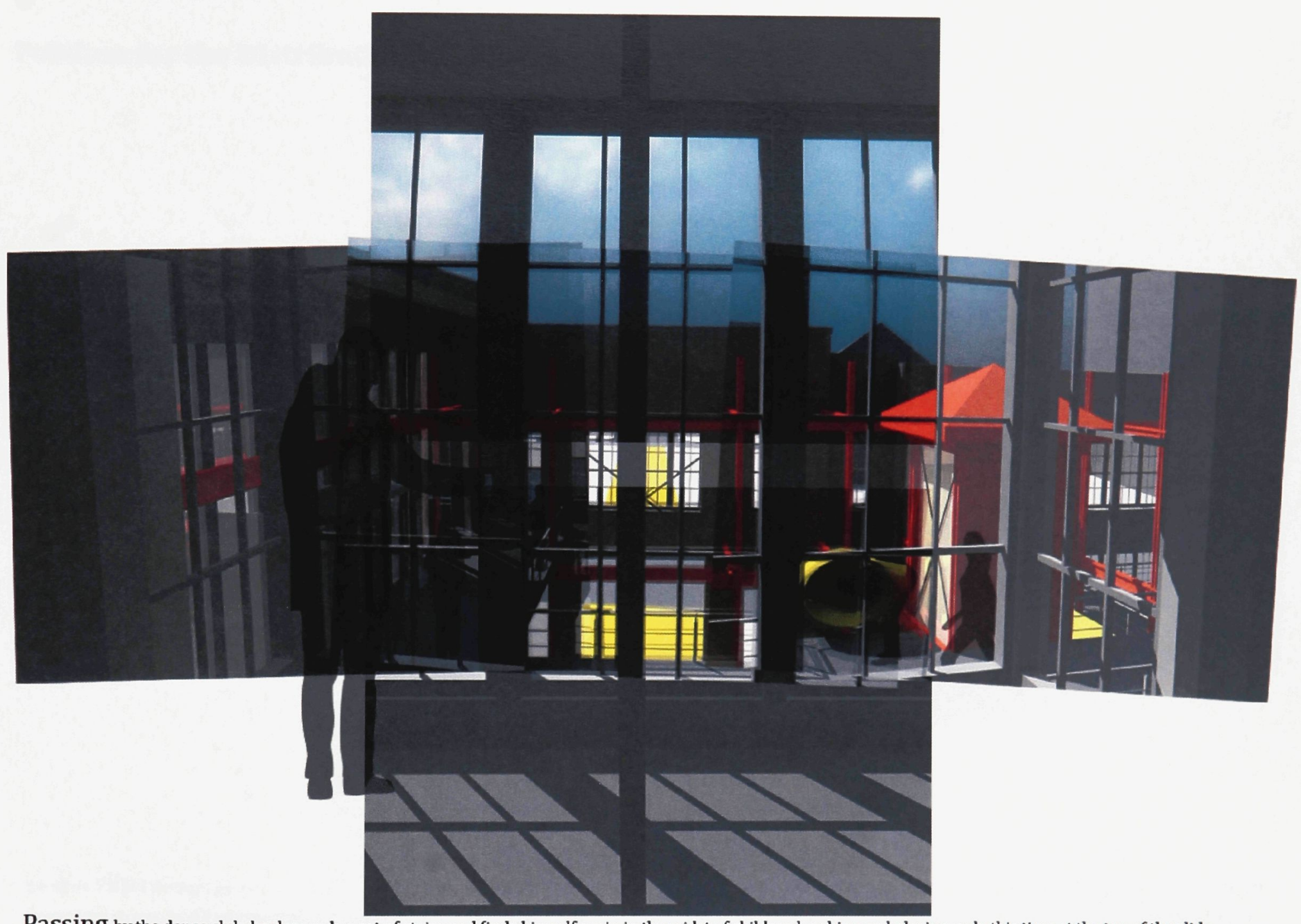

Passing by the dance club, he descends a set of stairs and finds himself again in the midst of children laughing and playing, only this time at the top of the slide. Watching the almost Infinite stream of children running up the staircase, waiting to slip Into the darkness of the slide, he wonders if he too should see what all the excitement is about, but instead continues with his journey. 


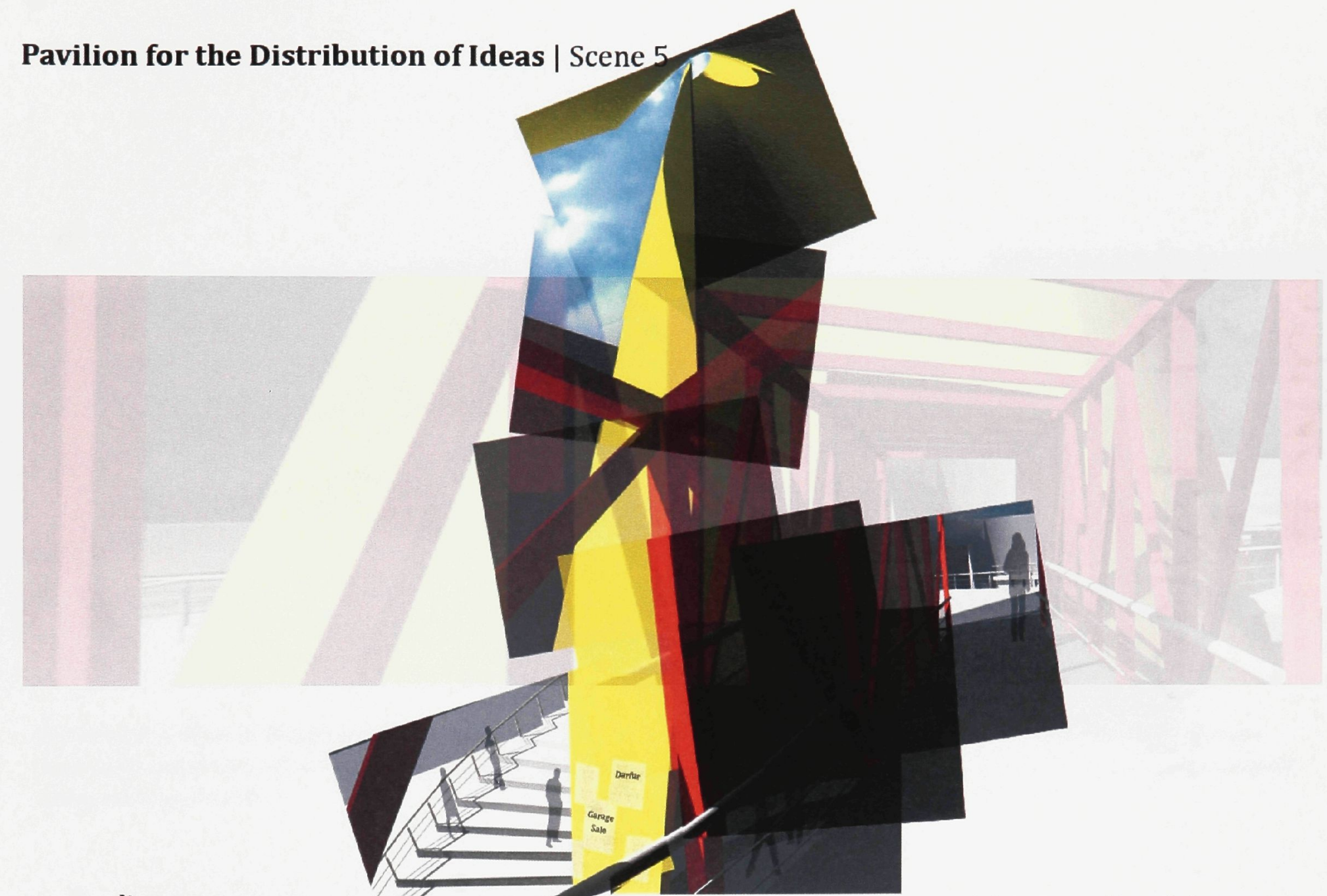

He again slips through the brick wall, etched muthtimenandinds hilmself on a bridge. Ahead of him lies an enormous conical structure reaching to the heavens. At the base of the structure, the entire exterior is plastered with posters which slowly fade upward like a pixelated image. He interrupts his journey to read several of them. One reads "Burma: Total Denial", another advertises a garage sale promising terrific deals this Saturday. He takes a mental note and continues forward. Inside, under dim lighting, with the exception of a giant beam of light descending from the oculus above, he hears voices of reason. Peering down below he sees a small group of people seated in a circular fashion around the perimeter of the structure who are heatedly debating the plight of the people of Darfur. Interested in what they have to say, he pauses momentarily, reconstructs the entire conversation in his mind, and again continues with his journey. 
Theatre | Scene 6

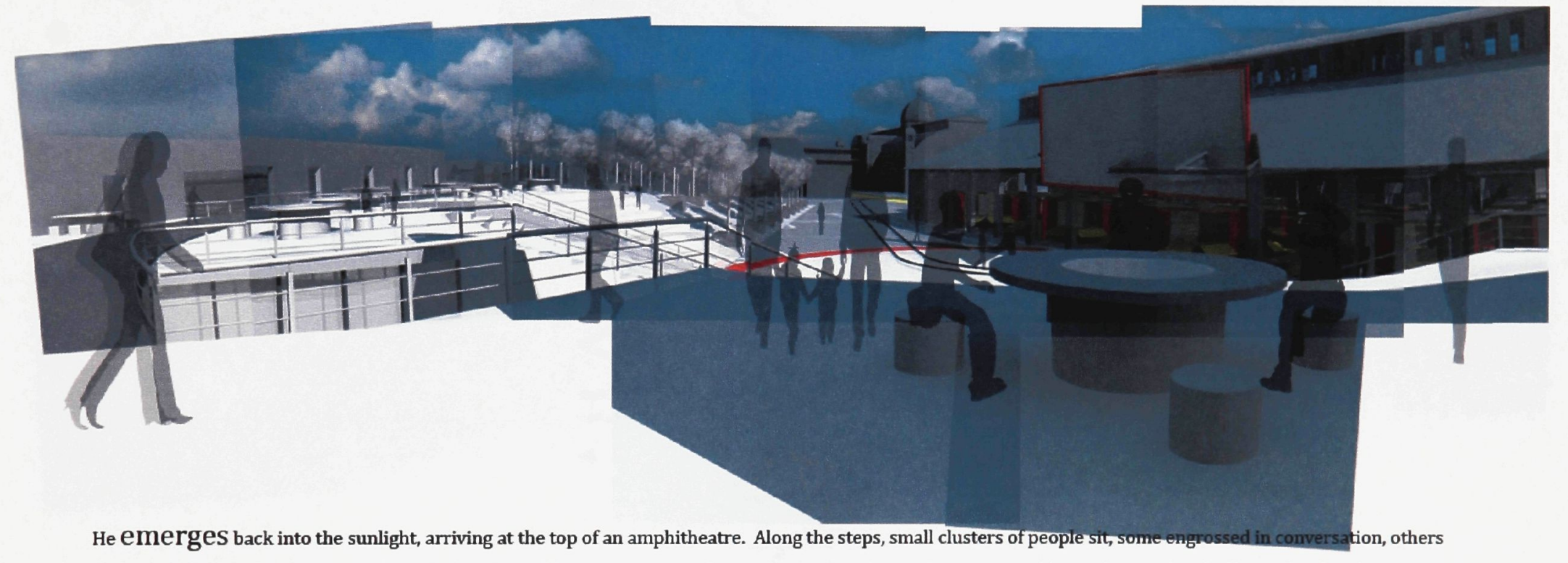

observing the spectacle of the market which is framed by a giant screen above Inserted into the market structure like a schism. Ahead of hlm a familly is having a picnic seated around a glass top table. 


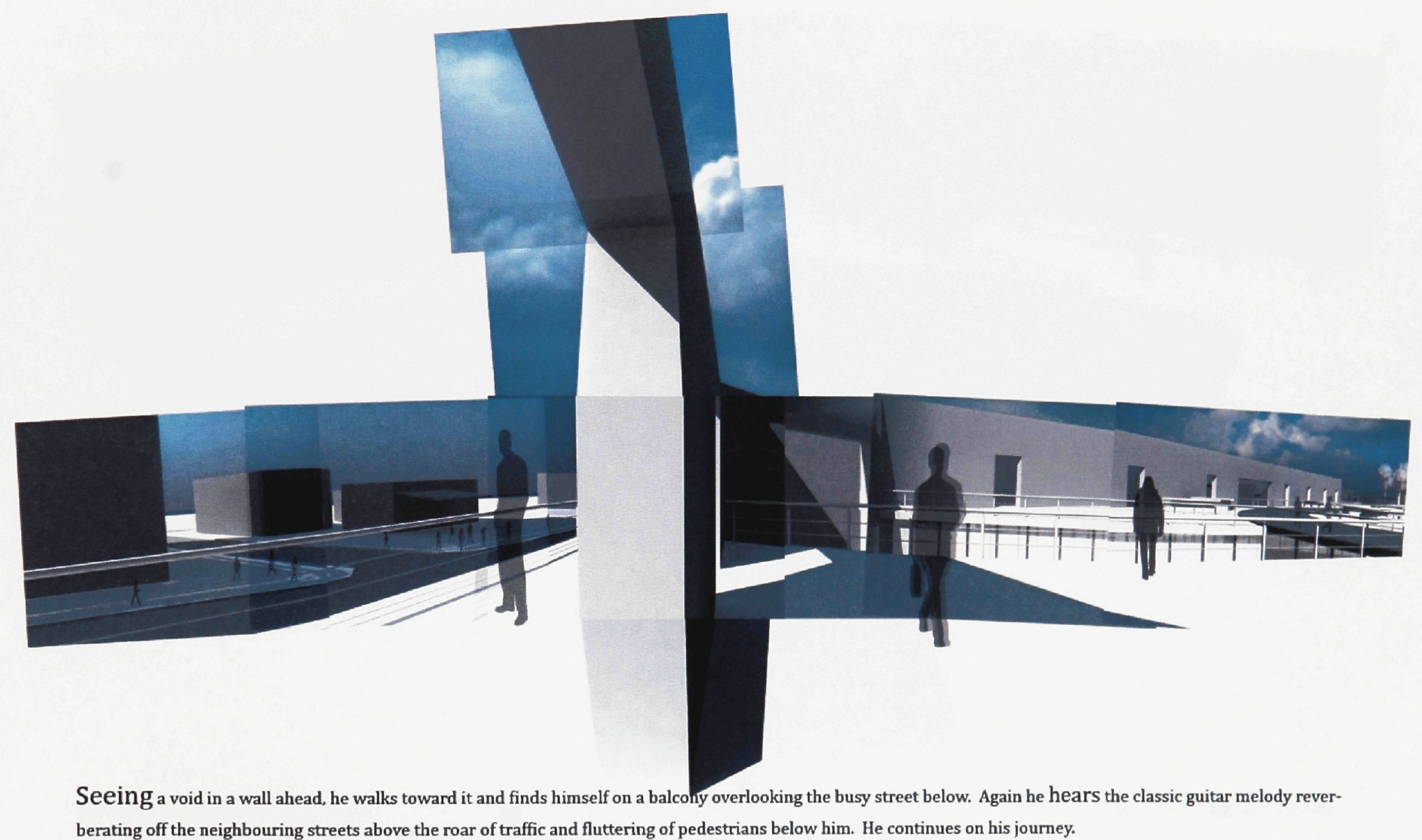

berating off the neighbouring streets above the roar of traffic and fluttering of pedestrians below him. He continues on his journey 


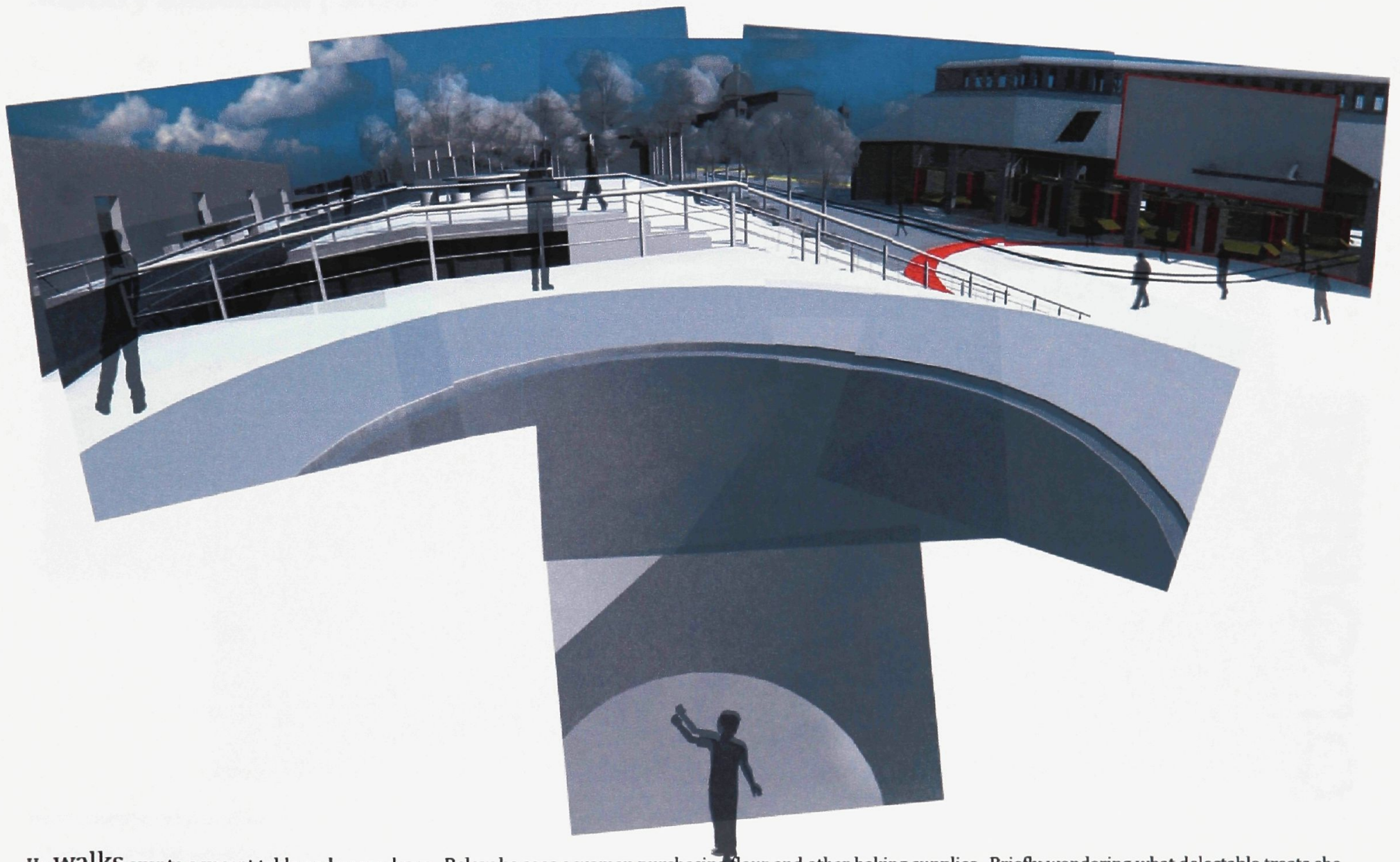

He WalkS over to a vacant table and peers down. Below he sees a woman purchasingiflour and other baking supplies. Briefly wondering what delectable treats she may have in store, he places his hand on top of the table interrupting the stream of light down below. His shadows dancing across the floor beneath causes the woman to look up, seeing the man, she smiles and continues with her shopping. The man continues with his journey. 


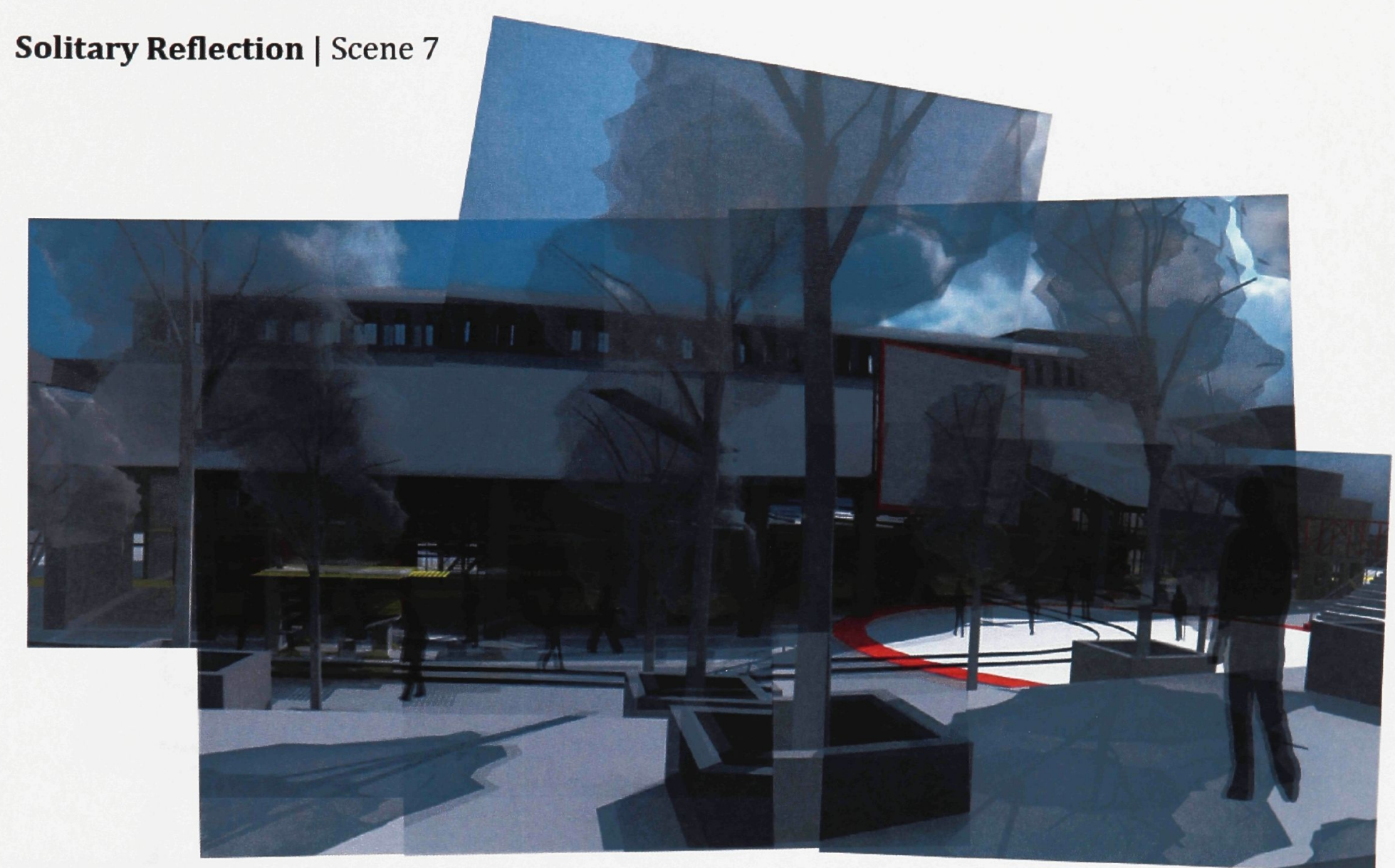

Now contained within a grove of trees, the man decides to sit in the shade and reflect upon all the events he has just witnessed. Briefly interrupting his stream of thoughts was the question about what brought him here in the first place. 


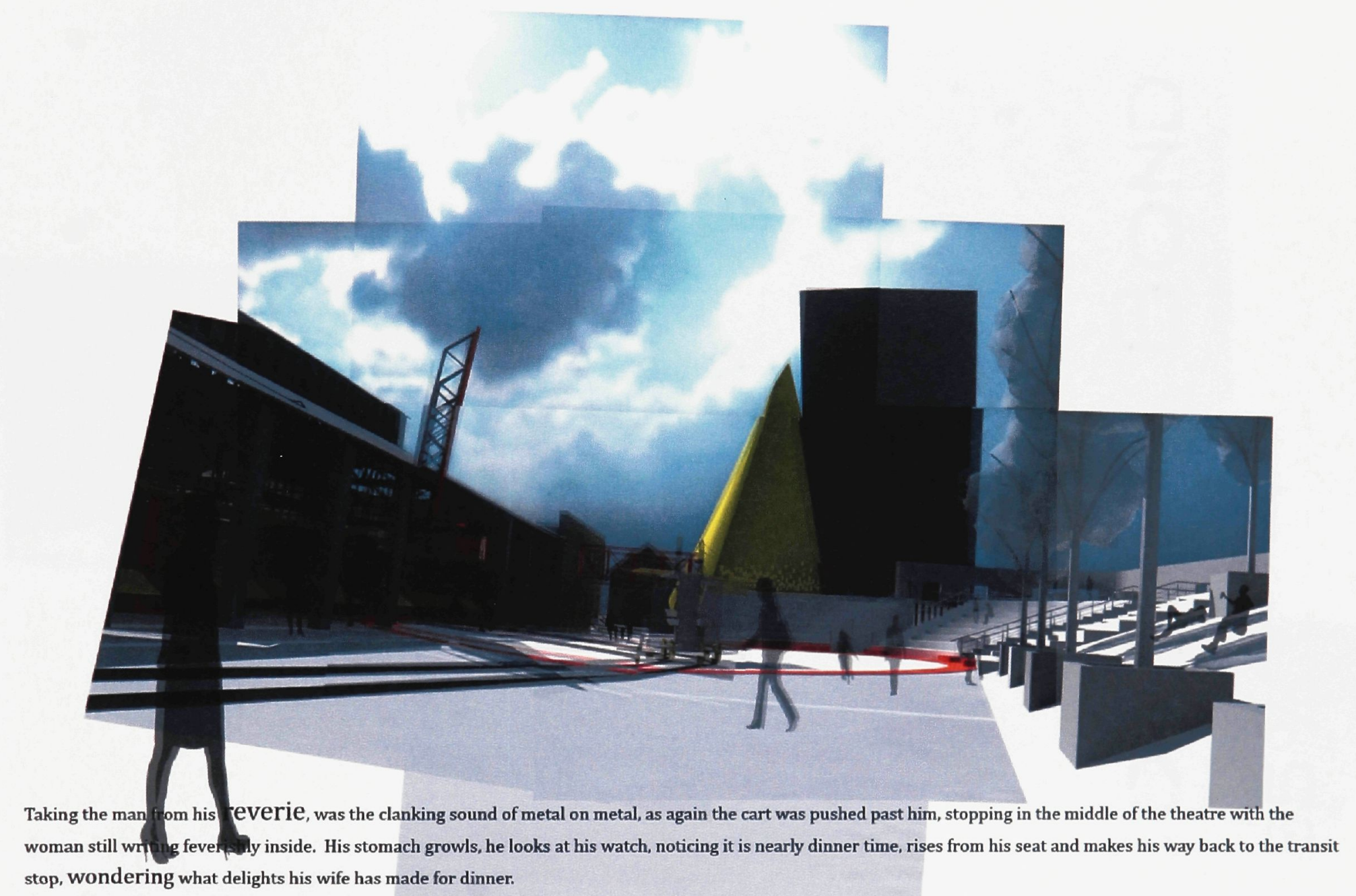




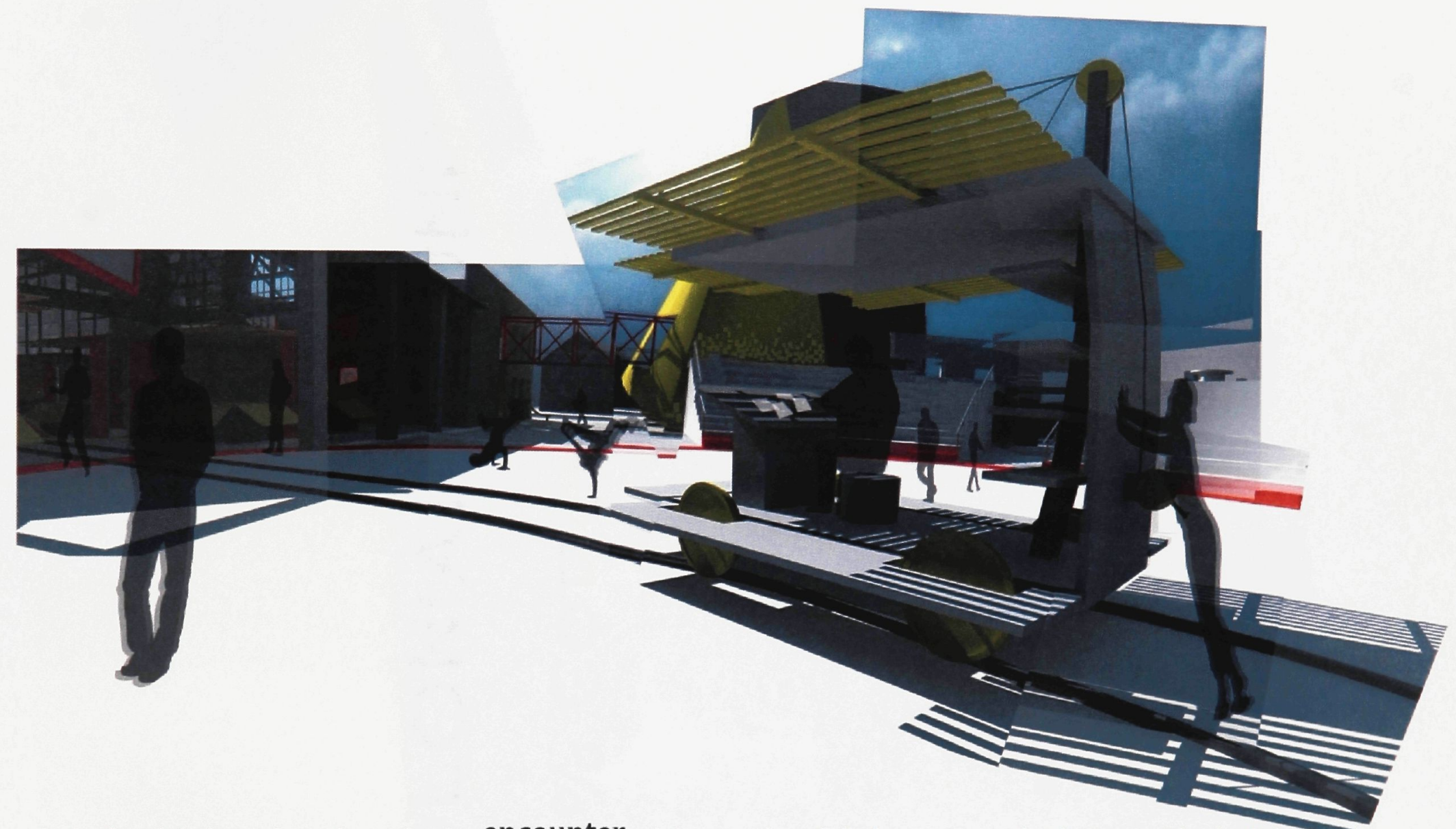

Passing through the theatre, the man has another close encounter with the cart. As he strolls by, the woman pauses from her writing and smiles. He knows, and she knows that they shared an unspoken bond, a passion for crowds and incognitos. 


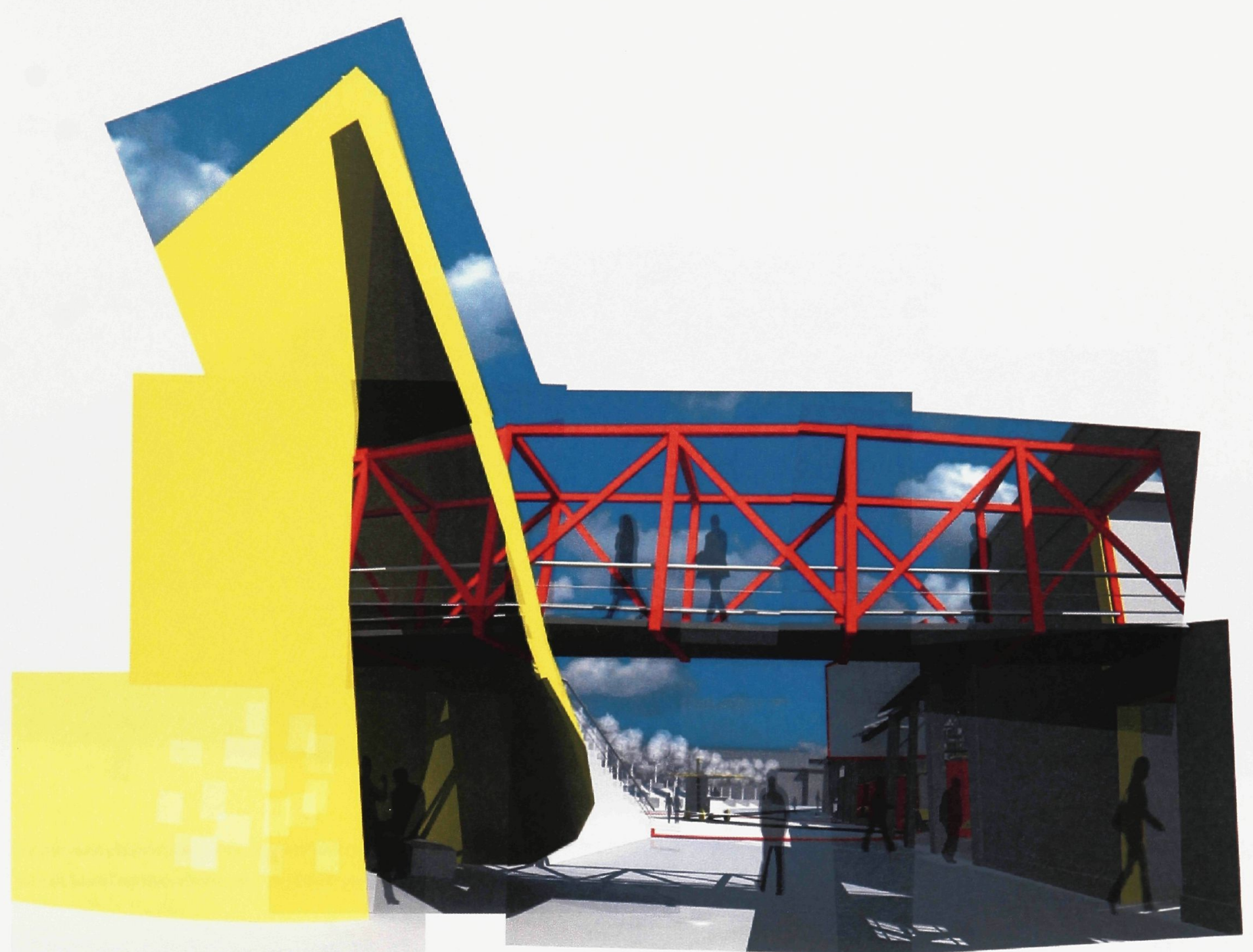

As he passes under the bridge the man walked over only moments earlier, he pauses to look back. Inside the cone, the men were still battling over political issues, the woman in the cart was still writing, and the other characters still constantly in flux, coming and going, each preoccupied with their own agendas, missing out on the beauty of the everyday; a beauty that will persist forever in memory constantly tied to this place. 


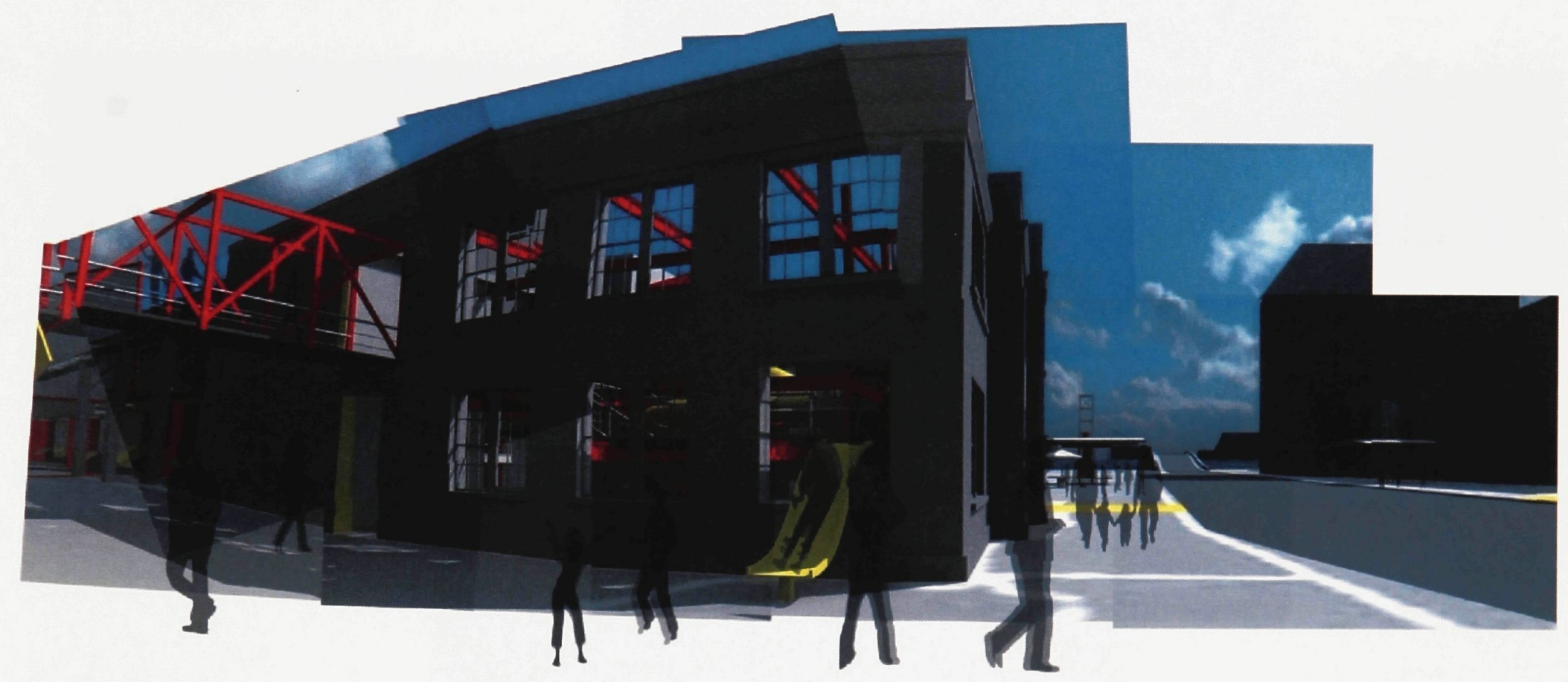

As the man rounds the corner, headed back out to the street to the departure point, a slightly intoxicated couple emerge out the slide out of a window, ready to wreak havoc on the market after no doubt spending an afternoon at the dance club. 
Departure | scene 8

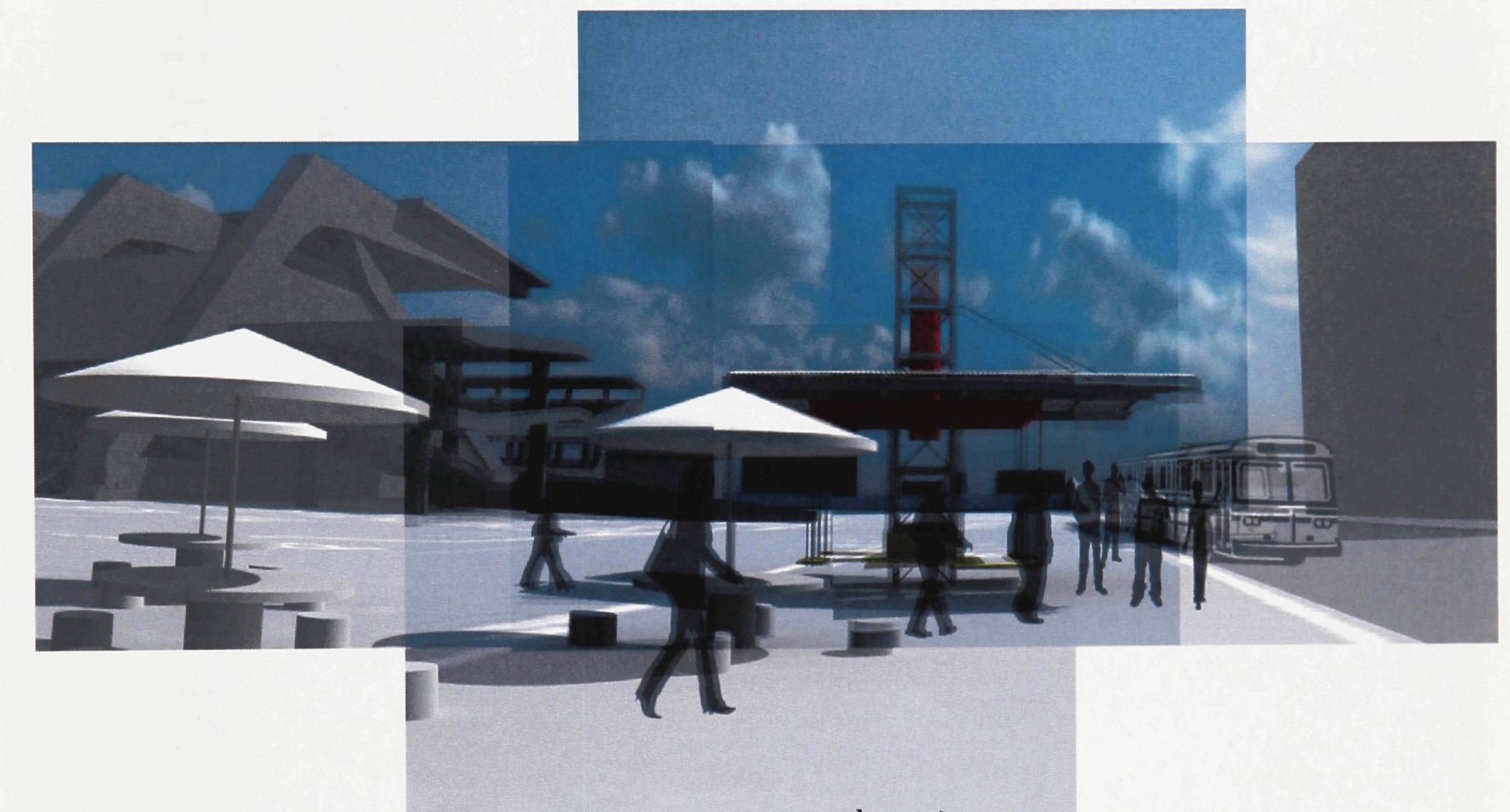

A bus pulls up, the man rises from his seat, the great mast above lowers, signally a change of characterS, this time his departure from the site. 


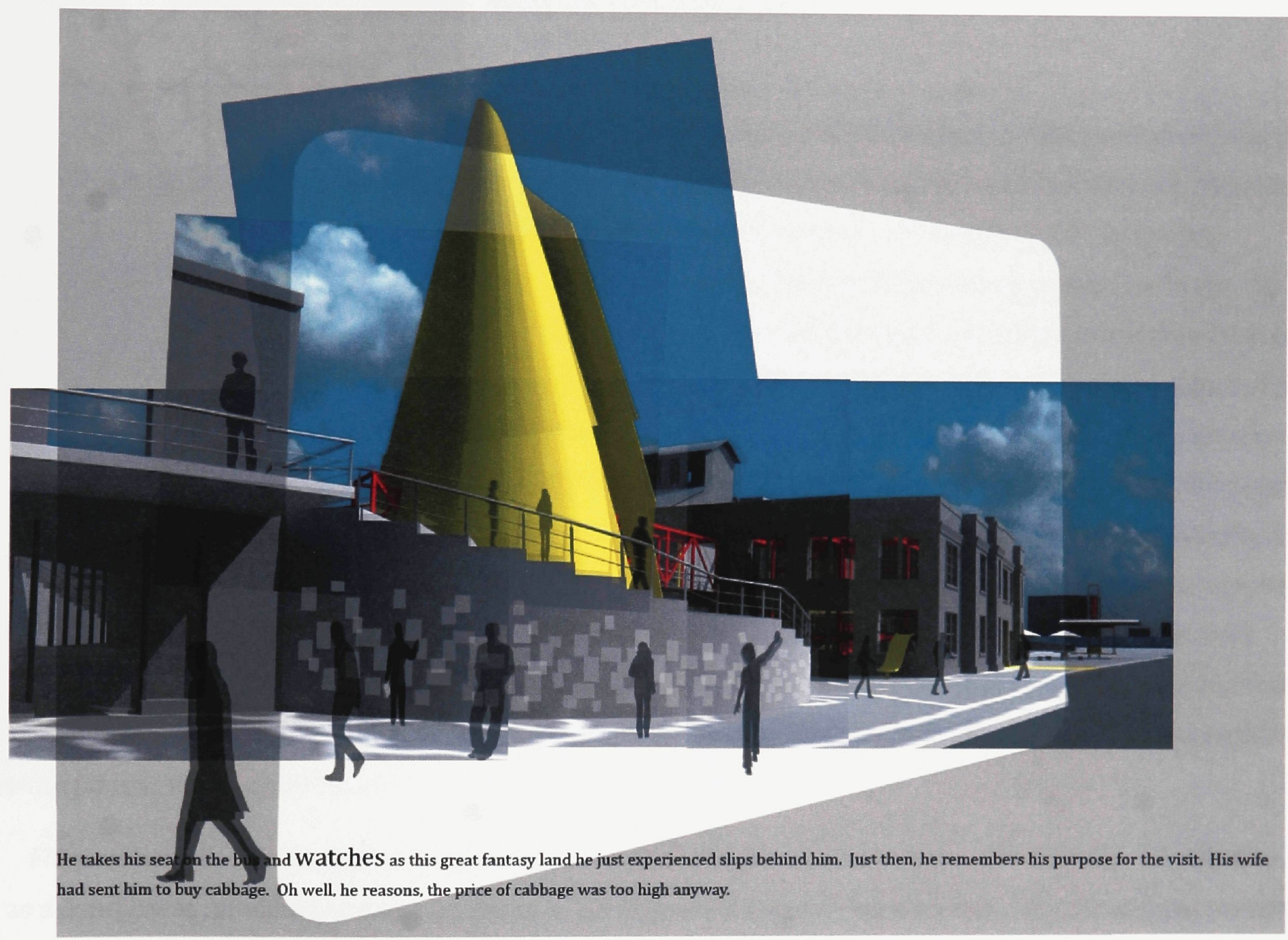




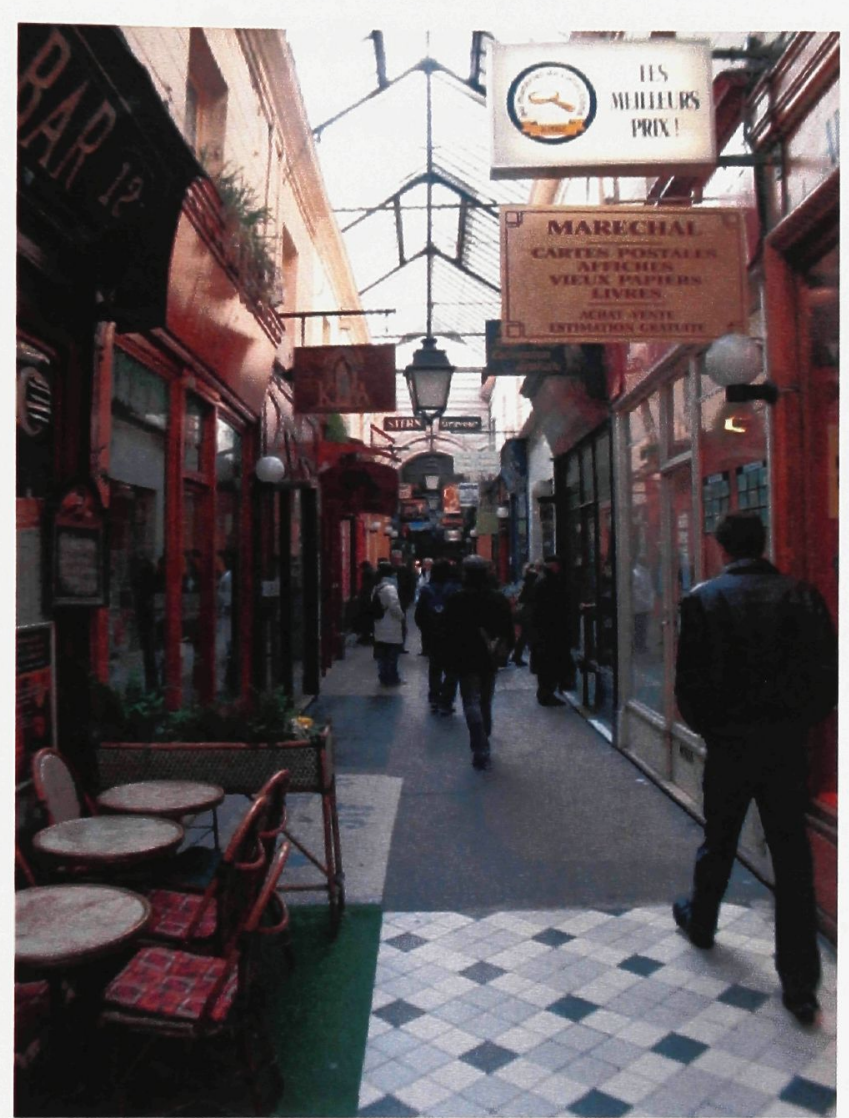

Parisian Arcades

\section{Who is the Flâneur?}

Flânerie, the act of intellectual strolling and observing the city as carried out by the flâneur is a recurring motif in literature, sociology, and urban art which has its roots in $19^{\text {th }}$ century Paris. In the pre-

Haussmannian days of Paris, wide pavements were rare in the city, and the narrow, winding streets offered the flâneur little protection from carts and carriages while he was "botanizing on the asphalt". The figure of flâneur could not have emerged without the commercial arcades that offered the pedestrian a safe place to wander and observe. The 1852 illustrated guide to Paris described the arcades as a "recent invention of industrial luxury... [They] are glass covered, marble-paneled passageways through entire complexes of houses whose proprietors have combined for such speculations. Both sides of the passageways, which are lighted from above, are lined with the most elegant shops, so that such an arcade is a city, even a world in miniature." 1 It is in this world where the flâneur first called home.

Flânerie became increasingly popular practice of the bourgeois of Paris in the $19^{\text {th }}$ century. The flâneur, often seen as a dandy, was unwilling to forgo his life as a "gentleman of leisure"; his laid-back lifestyle and personality was seen as protest to the division of labour which makes "people into specialists" and against the industrialization of individuals. ${ }^{2}$ The carefree idleness of the flâneur was synonymous with their resistance of the "work-a-day" pressures 
of the punch clock. It was also briefly fashionable for flâneurs to take turtles for walks in the arcades to set the tempo of their pace. The flâneur was characteristically a male figure. In Baudelaire's era and arguably still today, women were not safe alone on the streets. Women were seen as commodity, objects to be consumed by men.

The flâneur is more than a casual stroller of the streets; he is a detective of street life consuming the subtleties of the city, its sights, smells, characters and events; the secret observer of the spectacles of the city. Like a detective, the flâneur reads the urban landscape seeking clues to try to understand the social physiognomy of streets and their inhabitants. "The figure of the flâneur prefigures that of a detective. The flâneur should find a social legitimation for his behaviour. It suits him perfectly to see his indolence presented as a facade behind which he hides the sustained attention of an observer, never letting his eyes off the unsuspecting criminal." 3 The flâneur wanders the city in search for things to occupy his gaze, complete his identity, and satisfy his banal existence.

The flâneur plays a key role in participating, understanding, and portraying our urban environment. He moves through urban space with a viscosity that both facilitates and privileges his vision; reading crowds, the city, and the intersection of crowds with the city in order to decipher and interpret their meaning. It is his job to read what was never written. He is the impartial spectator of the modern world. He walks at will, seemingly without purpose, however through the eyes of the flâneur the city becomes an object of investigation and interpretation; the city unfolds as a "locus of signs": the semiotic city. "He is the painter of the passing moment and of all the suggestions of eternity that it contains." 4 The flâneur is in essence a product of modernity, providing an image of how that state of existence within a specific timeframe can be realized or at least understood.

The flâneur is a figure brought into being by Charles Baudelaire as both the spectator and depicter of modern life. Baudelaire's flâneur introduces us to his notion of modernity: "Modernity is the transient, the fleeting, the contingent; it is one half art, the other being the eternal and the immovable." 5 His essay entitled "The Painter of Modern 
Life" in conjunction with his poem "Crowds" from his Spleen collection are some of his best known works on the subject of flânerie and have been used to assemble the Baudelairean flâneur. To Baudelaire, the banal existence of modern domestic life was dull, and flânerie was the only means of escape from the feelings of crisis which Sartre was later to call nausea. ${ }^{6}$ The flâneur required relentless "bathing of the multitude" in order to suppress the feelings of incompleteness and gain existential satisfaction over the man who lives in a box, the "mollusk", the man who just is.

To Baudelaire, the flâneur viewed the urban landscape with a romantic curiosity akin to that of a young child. "The child sees everything in a state of newness; he is always drunk. Nothing more resembles what we call inspiration than the delight with which a child absorbs form and colour."7 The flâneur stalks and cruises the urban inferno discovering the metropolis as a landscape of voluptuous extremes, the flâneur finds the metropolis elating and picturesque. However, such views are always momentary, and invariably fragmentary. The flâneur is never afforded an overarching or panopticonic view of the city as a totality; it is always observed en passant. The continuous shifting of vantage points and assemblage of fragments recreates for the flâneur a montage of fleeting pictures; Benjamin's concept of the colportage phenomenon of space.

Baudelaire's Painter of Modern Life and flâneur derives from an artist named Constantin Guys. Although Guys existed as a real character and artist who portrayed daily life and existence, Baudelaire reinvents him as his prototypical flâneur, "a passionate lover of crowds and incognitos." 8 Through his work of defining daily life, Baudelaire reinvents his quests and daily routines. Although flânerie was independent of the significance of time which was emphasized by the fashion of taking turtles for walks, Baudelaire's invention of the day in the life of Constantin Guys [or Monsieur Guys as Baudelaire referred to him] suggested that flânerie was dependent upon the cyclical time of the day. The mainspring to understanding the genius behind Guys according to Baudelaire was his curiosity. Guys shares a 


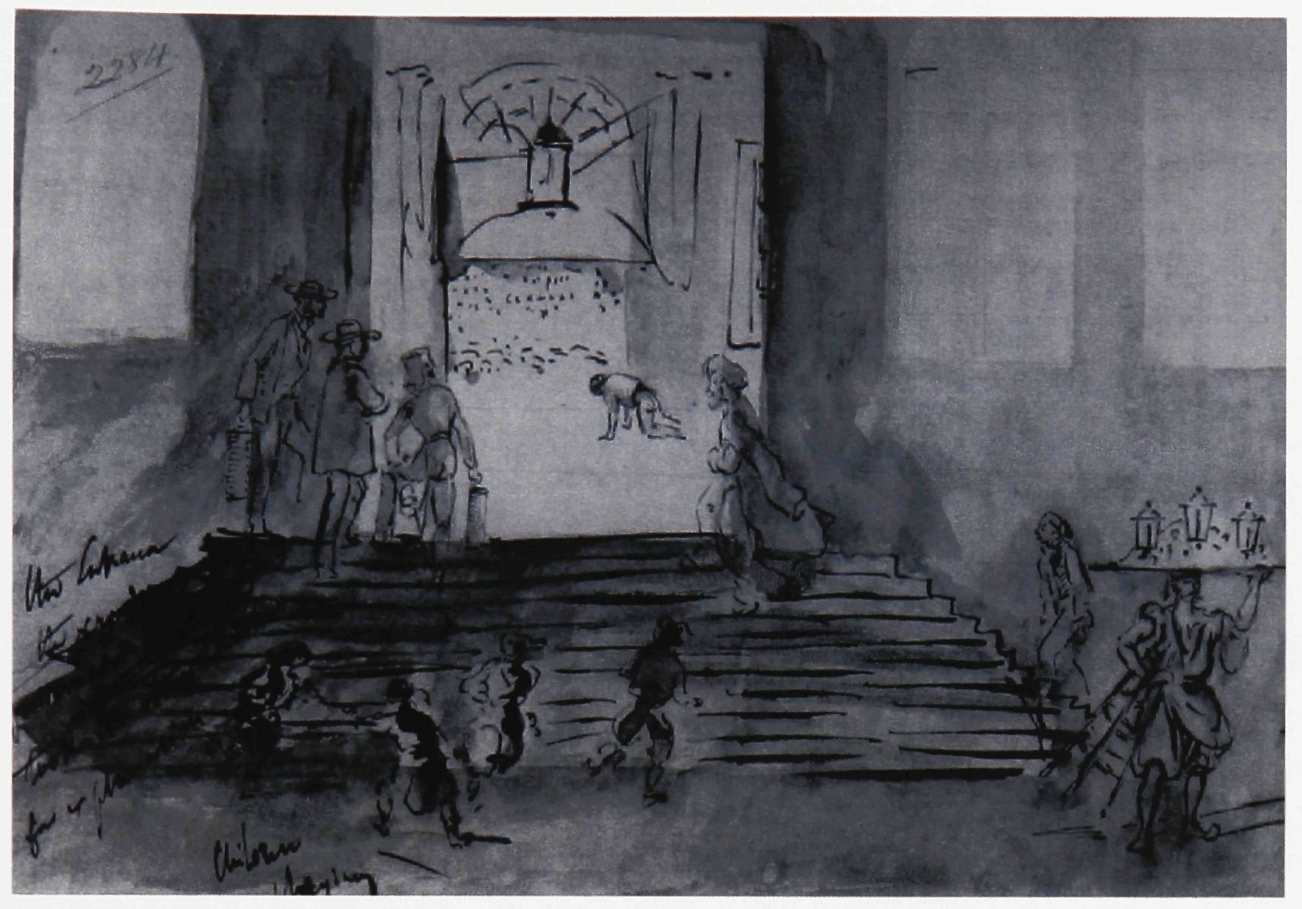

fig. 2

Ramadan in the Mosque of Top Hane, Constantinople Constantin Guys similar curiosity and convalescence that Baudelaire attunes with the main character of Edgar Allen Poe's story entitled "The Man of the Crowd"; where the character recovering from serious life threatening illness sits in a cafe window gazing at the crowd in the street, "mingling through the medium of thought, in the turmoil of thought that surrounds him." Finally giving in, he hurls himself into their midst, in pursuit of the unknown. "Curiosity has become a fatal irresistible passion." 9 Through this curiosity, Guys like a great mirror or "kaleidoscope gifted with consciousness" reproduces the multiplicity of life and its current state of modernity.

Flânerie is more specific than strolling; it is an individual practice of intellectually and spatially investigating the public realm; inhabiting city spaces, its streets, sidewalks, parks and squares. It is the act of strolling at an overtly leisurely pace allowing oneself to be lured and guided by the litmus of the city: crowds. Crowds gather in marketplaces, successful streets, and public spaces reacting to the sights, sounds and smells of the city. The crowd is the flâneur's domain. "The crowd is his element, as the air is that of the birds, and the water of fishes. His passion and profession are to become one flesh and one crowd. For the perfect flâneur, for the passionate spectator, it is an immense joy to set up house in the heart of the multitude, amid the ebb and flow of movement, in the midst of the fugitive and infinite. To be away from home and yet to feel oneself everywhere at home; to see the world, to be at the centre of the world, and yet remain hidden from the world."10 This passage accentuates the involvement of the flâneur within the public realm; and 
reveals the fluctuating relationship that exists between the flâneur and that of the collective: to be away from home and yet feel at home anywhere, to be at the very centre of the world, and yet remain hidden from the world. Paris, however familiar to Baudelaire gave him no sense of belonging; the crowds became his refuge and the streets the rooms where he worked. It was during his flânerie that Baudelaire composed many of his prose, at times of his life he did not even own a desk, forced to write while aimlessly wandering the streets:

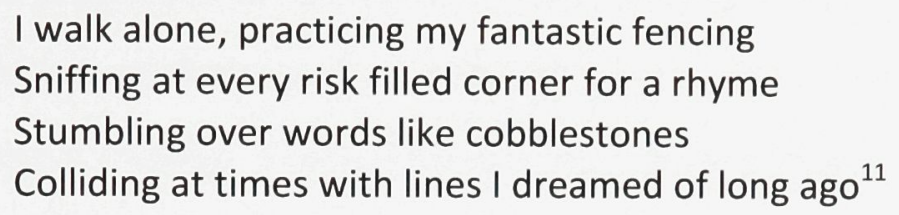

The flâneur has an interesting relationship with the crowd. His face and physiognomy is contained within the crowd; however, behind his face lies a secret nobility. The nobility of the flâneur comes from his reasoning of his mediocrity in the eyes of others. It is through this reasoning that the flâneur delights in the spectacle of the public. If the flâneur could be distinguished from the crowd, he would be unable to observe.

"Multitude, solitude: identical terms, and interchangeable by the active and fertile poet. The man who is unable to people his solitude is equally unable to be alone in a bustling crowd."12 Immersing himself into the masses he was able to lose his persona and adopt that of anyone of his choice. Baudelaire wrote of the flâneur: "The poet enjoys the incomparable privilege of being able to be himself or someone else, as he chooses. Like those wandering souls who go looking for a body, he enters as he likes into each man's personality. For him everything is vacant; and if certain places seem closed to him, it is only because in his eyes they aren't worth visiting."13 Baudelaire's physiognomy and appearance reportedly was altered every day. He became "his own impresario," exhibiting himself as different personalities and characters on the streets of Paris as flâneur, ragpicker, dandy, or whore. ${ }^{14}$ The anonymity of the 
crowd fuelled the exercise, and gave the flâneur the ability to determine for himself the meaning and "sovereignty" of the public spaces and spectacles that he observed. Baudelaire referred to the flâneur as a "prince" enjoying his incognito wherever he goes. The flâneur defines his own world and appearances rather than allowing things to define themselves. This "sovereignty" rooted in anonymity and observation means that for the flâneur the meaning and the importance of everything is alterable more or less at will. ${ }^{15}$ Imagination plays an important role in defining meaning and order, the flâneur can be whatever or whoever he wills himself to be; "he can put on masks and make the faces of strangers hide the sordid secrets of their souls." 16 The flâneur in a moment of passing, or based upon an auditory fragment reconstructs an entire reality. Victor Fournel once wrote concerning the imagination of the flâneur: "With the aid of a word I overhear in passing, I reconstruct an entire conversation, an entire existence. The inflection of a voice suffices for me to attach the name of a deadly sin to the man I have just jostled and whose profile I have just glimpsed."17 The power of fantasy is the only limit reality holds on the flâneur. "[Flânerie] is to rehearse contingency of meaning; life as a bagful of episodes none of which is definite, unequivocal, irresistible; life as a play." 18 Because the flâneur, this self-proclaimed monarch of the crowd's appearance is similar to everyone else in the crowd, nowhere is forbidden to him. The city spatially, morally, and culturally holds no mysteries for him; for him everything is vacant and inhabitable, unless in his eyes they aren't worth visiting.

It has been said that the flâneur is the most active, when he appears most idle. A vital concept to flânerie is the thought that the "fruits of idleness" are more valuable than the "fruits of labour". On this subject, the 19th century Pierre Larousse had the following to say about the flâneur:

"His eyes open, his ear ready, searching for something entirely different from what the crowd gathers to see. A word dropped by chance will reveal to him one of those character traits that cannot be invented and that must be drawn directly from life; those physiognomies so naively attentive will flourish the painter with the expression he was 
dreaming of; a noise, insignificant to every other ear, will strike that of the musician and give him cue for a harmonic combination; even for the thinker, the philosopher lost in his reverie, this external agitation is profitable: it stirs up his ideas as the storm stirs the waves of the sea... Most men of genius were great flâneurs-but industrious, productive flâneurs. . Often it is when the artist and the poet seem least occupied with their work that they are most profoundly absorbed in it. In the first years of this century, a man was seen walking each day and every day-regardless of weather, be it sunshine or snowaround the ramparts of the city of Vienna. This man was Beethoven, who, in the midst of his wanderings, would work out magnificent symphonies in his head before putting them down on paper. For him, the world no longer existed; in vain would people greet him respectfully as he passed. He saw nothing, his mind was elsewhere." 19

A dialectic exists between the sovereignty of the individual and his imagination to define meaning and order and the contingencies of the spectacles of the crowd. "What men call love is a very small, restricted, feeble thing compared with this ineffable orgy, this divine prostitution of the soul giving itself entire, all its poetry and all its charity, to the unexpected as it comes along, to the stranger as it passes." 20 The random and chance events of the street life are what the flâneur is after. It is these events that provide the flâneur with great poetic inspiration, and satisfy his banal existence. Benjamin writes of this great intoxication that consumes the flâneur, continually drawing him further down the streets with ever increasing momentum, "ever weaker grow the temptations of shops, of bistros, of smiling women, ever more irresistible the magnetism of the next street corner." 21 Baudelaire writes of the solitary mortal who is endowed with an active imagination who roams through the "great desert of men", men trapped in their mollusk shells, seeking out the fleeting pleasure of circumstance; this is the aspiration of the flâneur.

Flânerie is one of the main narrative devices utilized by Baudelaire in his 1869 collection entitled Paris Spleen. Not only does Baudelaire provide insight into the life of the flâneur, but the sequencing of the prose takes us on an 
aimless wander through the chance events of Parisian life. Baudelaire does not describe the city, but rather it is the scene of the action. Baudelaire's flâneur is a man of the crowd as opposed to Edgar Allan Poe's man in the crowd. Although he appears to be just one constituent of the metropolitan flux, he is at the centre of his own making-a panopticonic viewpoint where scenes and events unfold around him in every direction. It is the sense of being of rather than in which differentiates the flâneur from all others in the crowd. Benjamin makes this important distinction between the flâneur and the "rubberneck" (badaud) or tourist: the flâneur is always in control of his individuality; while the rubberneck fades away, absorbed by the external world. Lost in the spectacle, the rubberneck no longer is a man, no longer a personal being; he becomes the public, one with the crowd. ${ }^{22}$

Many believe that the flâneur is specific to the culture and time of $19^{\text {th }}$ century Paris and could not and cannot have existed elsewhere. However, social and literary analysis of the figure of the flâneur has understood him to be a symbolic representation of modernity and personification of contemporary urbanity. ${ }^{23}$ Baudelaire never made any distinction between Paris and modernity, which leaves the impression that he was not sure which he was writing about or, if indeed both. Benjamin also has a similar issue when writing about the flâneur; he has no problem referring to Berlin, Vienna, or London to reinforce his ideas. In fact, Benjamin stresses the importance of Poe's “The Man of the Crowd", a story set in London of a man who seeks out the crowd because he is not comfortable with himself.

Baudelaire's flâneur began to move out of the arcades and streets and into the department stores looking to fashion as a means of understanding the current state of modernity. Fashion contains the moral and aesthetic feeling of our time. Fashion or man's idea of beauty goes beyond dress but imprints itself on his complete attire; it affects his gait, squares his gesture, and penetrates his face. "Looking for that quality which you must allow me to call 'modernity'; for I know no better word to express the idea that I have in mind. [the flâneur] makes it his business to extract from fashion whatever element it may contain of poetry to distil the eternal from the transitory." 24 Baudelaire's empathy 
with the commodity is what leads to the eventual decline of the flâneur. The practice of flânerie enters into recession when it loses its connection to the city.

\section{Notes}

${ }^{1}$ Walter Benjamin, Charles Baudelaire: A Lyric Poet in the Era of High Capitalism. trans. Harry Zohn. (London: Verso Publishing, 1983) 3637

${ }^{2}$ Benjamin, Charles Baudelaire: A Lyric Poet in the Era of High Capitalism 54

${ }^{3}$ Walter Benjamin, The Arcades Project. trans. Howard and Kevin McLaughlin Eiland (Cambridge: Belknap Press, 1999$) 442$

${ }^{4}$ Charles Baudelaire, The Painter of Modern Life. (London: Phaidon Press, 1964) 5

${ }^{5}$ Charles Baudelaire, Selected Writings on Art and Artists. trans. P.E. Chavet (Harmonsworth: Penguin, 1970) 403

${ }^{6}$ Keith Tester, "The Flâneur." Tester, Keith. The Flâneur. ed. Keith Tester (London: Routledge, 1994) 2 Also Jean-Paul Sartre, Nausea. trans. Lloyd Alexander (New York: New Directions, 1964)

${ }^{7}$ Charles Baudelaire, The Painter of Modern Life \& Other Essays. (London: Phaidon Press, 1964) 8

${ }^{8}$ Baudelaire, The Painter of Modern Life \& Other Essays. 5 
${ }^{9}$ Baudelaire, The Painter of Modern Life \& Other Essays. 7

${ }^{10}$ Baudelaire, The Painter of Modern Life \& Other Essays. 9

${ }^{11}$ Susan Buck-Morss, The Dialectics of Seeing: Walter Benjamin and the Arcades Project. (Cambridge, Massachusetts: The MIT Press, 1991) 185

${ }^{12}$ Charles Baudelaire, Paris Spleen. trans. Louis Varnese (New York: New Directions Publishing, 1970) 20

${ }^{13}$ Baudelaire, Paris Spleen. 20

${ }^{14}$ Buck-Morss, The Dialectics of Seeing: Walter Benjamin and the Arcades Project. 187

${ }^{15}$ Tester, The Flâneur. 4

${ }^{16}$ Tester, The Flâneur. 5

${ }^{17}$ qtd. in: Benjamin, The Arcades Project. 431

Originally Cited: Victor Fournel, Ce qu'on voit dans les rue de Paris [What one sees on the streets of Paris] (Paris 1858) 270

${ }^{18}$ Zygmunt Bauman, "Desert Spectacular." ed.Tester, Keith. The Flaneur. (London: Routledge, 1994) 142

${ }^{19}$ qtd. in: Benjamin, The Arcades Project. 453-454

Originally Cited: Pierre Larouse, Grand Dictionnaire Universel (Paris, 1872), vol.8, 436

${ }^{20}$ Baudelaire, Paris Spleen. 20

${ }^{21}$ Benjamin, The Arcades Project. 417

${ }^{22}$ Benjamin, The Arcades Project. 429

${ }^{23}$ Priscilla Parkhurst Ferguson, "The Flâneur On and Off the Streets of Paris." ed.Tester, Keith. The Flâneur. (London: Routledge, 1994) 22

${ }^{24}$ Baudelaire, The Painter of Modern Life \& Other Essays. 12 


\section{Flâneur as Consumer}

To many, thanks in part to Walter Benjamin's reading of Baudelaire as published in his Passagen-Werk (Arcades Project), the flâneur is seen as a bygone figure left to die alone on the streets of $19^{\text {th }}$ century Paris. "The flâneur is someone abandoned in the crowd. In this he shares the situation of the commodity....The intoxication to which the flâneur surrenders is the intoxication of the commodity around which surrenders the stream of customers." ${ }^{1}$ Benjamin argues that commodification and the distribution of commodities within the city defined the meaning of existence in the city leaving no spaces of mystery left for the flâneur to observe. Capitalism forced its own order on the city from the outside. Benjamin proposes that the shallowness of both capitalism and commodity form are reflected in the flâneur. "The flâneur only seems to break through this 'unfeeling isolation of each in his private interest' by filling the hollow spaces created in him by such isolation, with the borrowed - and fictitious - isolations of strangers."2 The flâneur is merely a passive spectator duped by the spectacle of the consumerist public who in turn is duped by the glittering promises of consumerism.

Not only does Benjamin see the flâneur as an archetypical consumer, but he himself is out to be consumed. "The man of letters puts himself on the market, in as much as he is a flâneur, to sell himself."3 The figure of the flâneur could be associated with that of the prostitute, who is characterized as a person-become-commodity. In the second stanza of Baudelaire's poem Crowds: "The poet enjoys the incomparable privilege of being able to be himself or someone else, as he chooses. Like those wandering souls who go looking for a body, he enters as he likes into each man's personality. For him everything is vacant; and if certain places seem closed to him, it is only because in his eyes they aren't worth visiting." ${ }^{4}$ Benjamin believes that the commodity itself is the speaker here. It is in the last words that the commodity 
speaks out to the "poor wretch" who passes by the shop window full of luring, expensive, beautiful things. These items, Benjamin argues, are not interested in this person; they do not sympathize with him, but empathize with the fetishized inorganic objects which became a great source of inspiration to Baudelaire. "The flâneur is the observer of the marketplace. His knowledge is akin to the science of industrial fluctuations. He is a spy for the capitalists, on assignment in the realm of consumers." 5

The flâneur is constantly bombarded with varying opinions on the street, under relentless pressure from commodification which Benjamin argues was vital to the development of $19^{\text {th }}$ century Paris. Intellect and reason take a back seat to the desires roused by the city as the flâneur surrenders to the excessive displays of capitalist merchandise. Contrary to Buck-Morss' belief of the automobile as the reason for the "death" of the flâneur, Parkhurst-Ferguson believes that the development of mercantile capitalism forced the flâneur off the streets and into the department stores long before the introduction of the automobile. ${ }^{6}$ Once there, flânerie was transformed into a feminine pursuit. Even though the transition from the arcades to the department store seems like a logical step, it is a transition from a space that is both public and private to a realm that is entirely private. In the arcades, the flâneur still maintains a relationship to the city that is symbolic of the society at large; he is neither fully outside in the streets, nor entirely inside the shops. The flâneur passes by shop windows "tasting" their delights without consuming them in a practice Balzac refers to as "gastronomy of the eye."7 Once inside the department store, the flâneur completely loses the connection to the city, lost in the consumption of capitalism; abolishing the flâneur of his distinctive status as observer of the city and his hold on his creative genius. The feminization of the flâneur or flâneuse redefines the practise of flânerie out of existence; the flâneur goes shopping after all. "Empathy with the commodity is fundamentally empathy with the exchange value itself. The flâneur is the virtuoso of this empathy. He takes the concept of marketability itself for a stroll. Just as his final ambit is the department store, his last incarnation is the sandwich-man"8 
Notes

${ }^{1}$ Walter Benjamin, Charles Baudelaire: A Lyric Poet in the Era of High Capitalism. trans. Harry Zohn (London: Verso Publishing, 1983$) 55$

${ }^{2}$ Benjamin, Charles Baudelaire: A Lyric Poet in the Era of High Capitalism. 58

${ }^{3}$ Walter Benjamin, The Arcades Project. trans. Howard and Kevin McLaughlin Eiland (Cambridge: Belknap Press, 1999) 463-464

${ }^{4}$ Charles Baudelaire, Paris Spleen. trans. Louis Varnese (New York: New Directions Publishing, 1970) 20

${ }^{5}$ Benjamin, The Arcades Project. 427

${ }^{6}$ Priscilla Parkhurst Ferguson, "The Flâneur On and Off the Streets of Paris." ed.Tester, Keith. The Flâneur. (London: Routledge, 1994) 34

${ }^{7}$ Parkhurst Ferguson, "The Flâneur On and Off the Streets of Paris." 35

${ }^{8}$ Benjamin, The Arcades Project. 448 


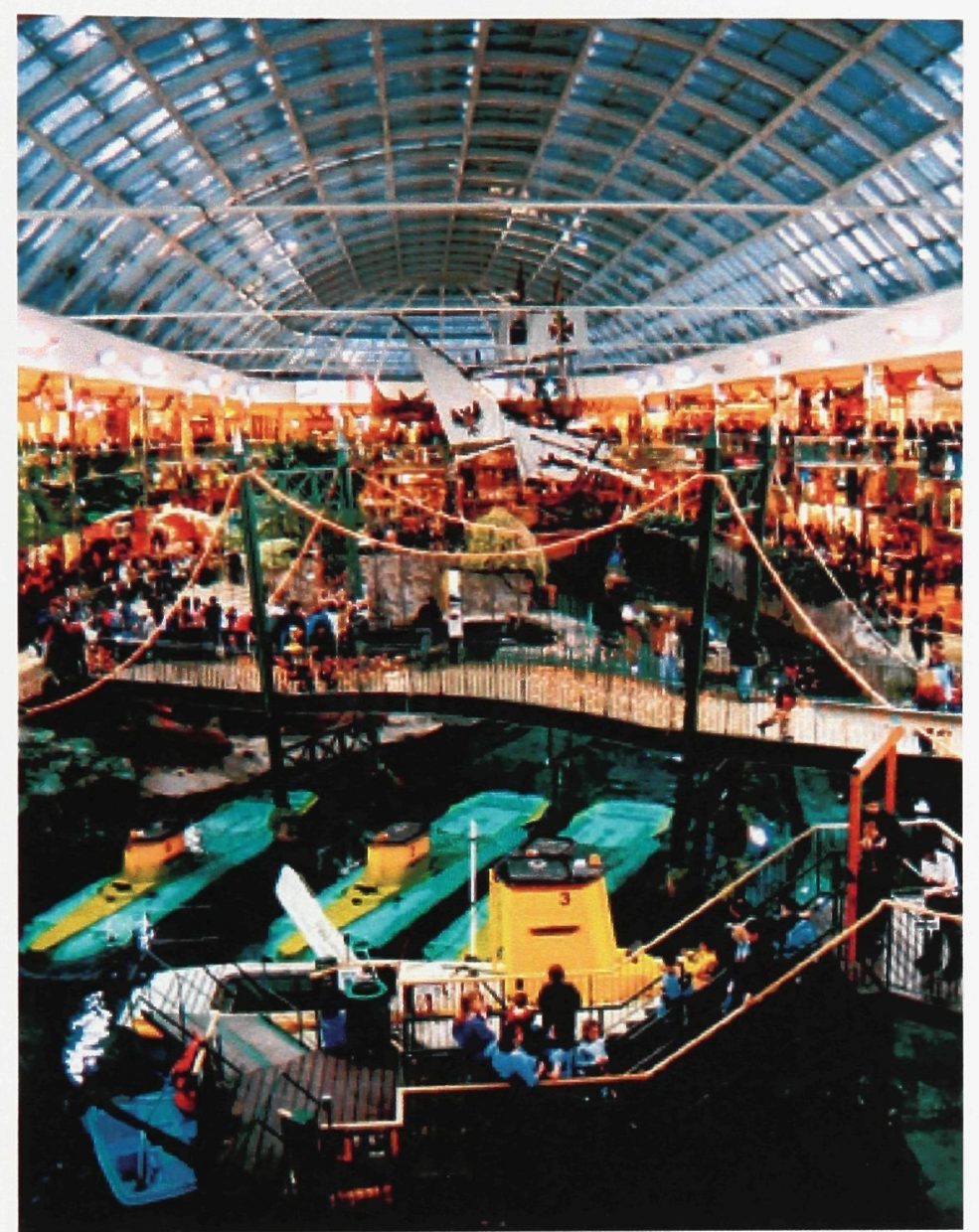

West Edmonton Mall by Author

\section{Flânerie Expropriated}

More recently capitalism has forced the expropriation of the flâneur or flânerie through the selling of public space in the form of theme parks, packaged vacations, and corporate shopping centres that are meant to dazzle, dupe and seduce, rendering the aimless obsolete. Although they may appear as it may seem worlds "made to the flâneur's measure," an evolution of the Parisian Arcades that draw crowds of unprecedented quantity, they are worlds "without residue or alternative." Such worlds detract from the flâneur as the centre of his making, he is no longer in complete control; for in the worlds of Disney Space ${ }^{1}$ and Las Vegas, "real reality" has already been squeezed out; there is no room for the flâneur to invent, no world to play. The flâneur becomes a tourist, rubberneck, a baudad, forced to submit to the glittering promises of consumerism. After a

visit to West Edmonton Mall in Alberta, Canada; where every day is an artificial conglomeration of shopping and fantasy in the synthetic climate controlled spaces irregardless of the Albertan blizzards outside, David Hill noted: "The pursuit of aimless leisure here approaches the surreal... When you visit West Edmonton Mall and its avalanche of attractions, there is only one thing to do-hand in your coat at the cloakroom and submit."2 Disney Space, upon paying an entry admission, admits one to a world fantasy: living and play have reversed roles. Inside Disney Space, Main Street guised 
as a shrewd commercial reality contains tiny "toy" houses and shops that invite entry; once inside they become supermarkets of compulsive commercialism which function according to the belief that one is still "playing." The liberty of the flâneur to set playfully the aims and meaning of his wanderings has been expropriated.

\section{Notes}

1 "Disney Space" is a term coined to represent the cinematic approach to theme park design developed by Walt Disney where every step is choreographed; a modern consumerist approach to the English picturesque garden.

\footnotetext{
${ }^{2}$ Zygmunt Bauman, "Desert Spectacular." ed.Tester, Keith. The Flaneur. (London: Routledge, 1994) 150
} 


\section{The Flâneur as travelling player/play[write]}

The joy of wandering is the joy of playing; some might say wandering without aim, casually stopping to look around is the ultimate form of play. The Dutch philosopher Johan Huizinga, preferred the terminology homo ludens [he who plays] to the more popular homo sapien, as he believed it was the act of play which separated man from the rest of the living creatures. ${ }^{1}$ The flâneur is a travelling player; he takes his play with him wherever he goes. As a player, it is his game to make others play, to view others around him as players, and to make the world a world of play. Of this world of play, he is in complete control; he is the playwright, director, actor, and audience. "The job of the flâneur is to rehearse the world as theatre, life as a play."2 Through this form of play, the flâneur can put on masks rejoicing in his incognito, diluting or escalating the value of those around him.

It was the arcades that became the first stages of the flâneur's theatre; safe havens to offer the pleasure of observing, and attracting the seekers of this spectacle. As flânerie moved out into the streets, staircases, steps and stoops formed impromptu stages and seating from which to observe the crowd. Will Eisner preferred the vantage points of stoops from which to observe the theatricality of urban life. He wrote of stoops, "Bleachers in a stadium are the tenement stoops, a drawbridge, a common, a stagelet too; safe seats in the arena of the city from which to watch the parade of life."3 Not all streets are befitting to that of the flâneur/playwright; "The society that set the flâneur off on his perpetual voyage of discovery, which made him into the player expecting the world to be a play, had to supply him with a world fit for the play of discovery." ${ }^{4}$ Streets must be wide enough to allow the flâneur to pause and look around. Like the Parisian arcades that became social destinations themselves and lured those with time to linger and mill about; the 
arcades were spaces to be in, not just pass through. Secondly, like the arcades lined with their elegant shops, the streets must be adjacent to shops, restaurants, clubs, and public spaces that will entice the flaneur's actors to the scene.

It is in this form of play[writing] that the flâneur-become-architect delights. Engrossed in the theatricality of the city, he becomes inspired by the events and spectacles that surround him. The flâneur-architect, cannot specifically design the spectacles, but can only "set the stage" for such spontaneous events and encounters to occur. He does this through inspiration drawn from successful streets and urban spaces; through the interpenetration, interrelation, and interfusion of program and events.

Notes

${ }^{1}$ Zygmunt Bauman, "Desert Spectacular." ed.Tester, Keith. The Flaneur. (London: Routledge, 1994) 142

${ }^{2}$ Bauman, "Desert Spectacular." 146

${ }^{3}$ Will Eisner, New York: Life in the Big City (New York: W.W. Norton \& Company Ltd., 2006) 17

${ }^{4}$ Bauman, "Desert Spectacular." 147 


\section{Flânerie as an Analytic Tool}

The importance of the flâneur is often underestimated, mostly in part due to the mystery intrinsic to his identity. Flânerie can be understood as the observation of the "fleeting and transitory". Louis Aragon in Paris Peasant wrote "the flâneur says important things about how we know where we are, how we become who we are, and how others become who we think they are, when all we know for sure is what we observe."1 Chris Jenks argues that although the Baudelairean flâneur may be dead, flânerie as an analytical tool and narrative device is not; it is an image of the movement through the social spaces of modernity; an assemblage of both Baudelaire and Benjamin's view of flânerie as source of poetic inspiration and analytical tool.

"The flâneur is a multilayered palimpsest that enables us to 'move' from real products of modernity, like commodification and leisured patriarchy, through the practical organization of space and its negotiation by inhabitants of a city, to a critical appreciation of the state of modernity and its erosion into the post-, and onwards to a reflexive understanding of the function, purpose, of realist as opposed to hermeneutic epistemologies in the appreciation of those previous formations." ${ }^{2}$

The flâneur being a product of modernity provides a snapshot of how that "being in time" is realized or understood. The flâneur, though anchored in everyday life provides an analytic form, a narrative device, an attitude toward knowledge within the social context. Alfred Delvau, who was a journalist and friend of Baudelaire, believed he could 
recognize the social strata of Parisian society through flânerie as easily as a geologist recognizes geological strata within the environment. ${ }^{3}$

The desire to diminish Baudelaire and the flâneur on the basis of commodity, Jenks argues stems from envy. To Baudelaire, in order for modern art to be valuable, it had to find "grand" or "heroic" subject matter; and this subject as Baudelaire pinned down was modernity itself. Modernity in Paris at that time came in the way of new commodities and shopping as a leisurely pastime. Jenks conveys an interesting notion that if the Baudelairean flâneur was displaced from the streets of $19^{\text {th }}$ century Paris to the New York of the 1960s, he may have found kinship in the subject matter of the paintings of Andy Warhol and Roy Lichtenstein, modernity as a form of surface which reveals its meaning and importance by virtue of its artificiality. ${ }^{4}$ In fact, Jenks believes that perhaps the flâneur with his "retracing steps" and "taking turtles for walks" would be more valuable as a cultural critic in the modern high-speed cities of today. In an age where civilization is expressed in the speed at which it runs, that there is no better place for the flâneur to "walk out of step" with the modern rhythms of society.

Flânerie provides a conceptual base from which to experience and understand urban space, community, and culture. Alternative cartographies of the city reveal the infinite potential of how streets and architecture define fragmented localities, as well as a sense of placement and identity. Different parts of the city carry with them different and multiple meanings developed through cultural dispositions, social history, or folklore; districts become designated as "safe", "naughty", or "dangerous". Flânerie breaks through these boundaries and defines the city based upon its events and spectacles.

Flânerie offers a useful and practicable metaphoric/methodological tool for the analysis of contemporary urban culture/architecture. When designing residential architecture, it is important for the architect to understand the needs of the client; so, too, in civic architecture, the architect must understand who he is designing for: the crowd. "We have 
not forgotten the dweller in the house and the crowd in the town." 5 Flânerie not only provides poetic and social inspiration to architects through reading the distinctive character of the urban metropolis, but physical and practical lessons can be learned as well: Places of social gatherings are observed and architectural logic for their popularity is deduced. Whether that is through shifts of scale or interrelation of program, the character of urban experience is observed. In particular forms of exclusion from public space and new forms of practice and perception can be introduced through observations as to where the collective culture is moving towards in the future. Flânerie provides opportunity to view playful juxtapositions of elements that comprise the city, planned or unplanned segregations, and reveal exciting relationships that may be missed by the casual stroller of the streets. It has even been said, that the flâneur does not choose his urbanity, he senses himself accountable for it; it is his inescapable fate. ${ }^{6}$

\section{Notes}

${ }^{1}$ Keith Tester, "The Flâneur." Tester, Keith. The Flâneur. ed. Keith Tester (London: Routledge, 1994) 8

${ }^{2}$ Chris Jenks, "Visual Culture." Chris, Jenks. Watching Your Step: the history and practice of the flaneur. (London: Routledge, 1995) 148149

${ }^{3}$ Walter Benjamin, Charles Baudelaire: A Lyric Poet in the Era of High Capitalism. trans. Harry Zohn (London: Verso Publishing, 1983) 39

${ }^{4}$ Jenks, "Visual Culture." 148

${ }^{5}$ LeCorbusier. Towards a New Architecture. (Mineola: Dover Publications, 1986) 18

${ }^{6}$ Tester, "The Flâneur." 8 


\section{My Flânerie...}

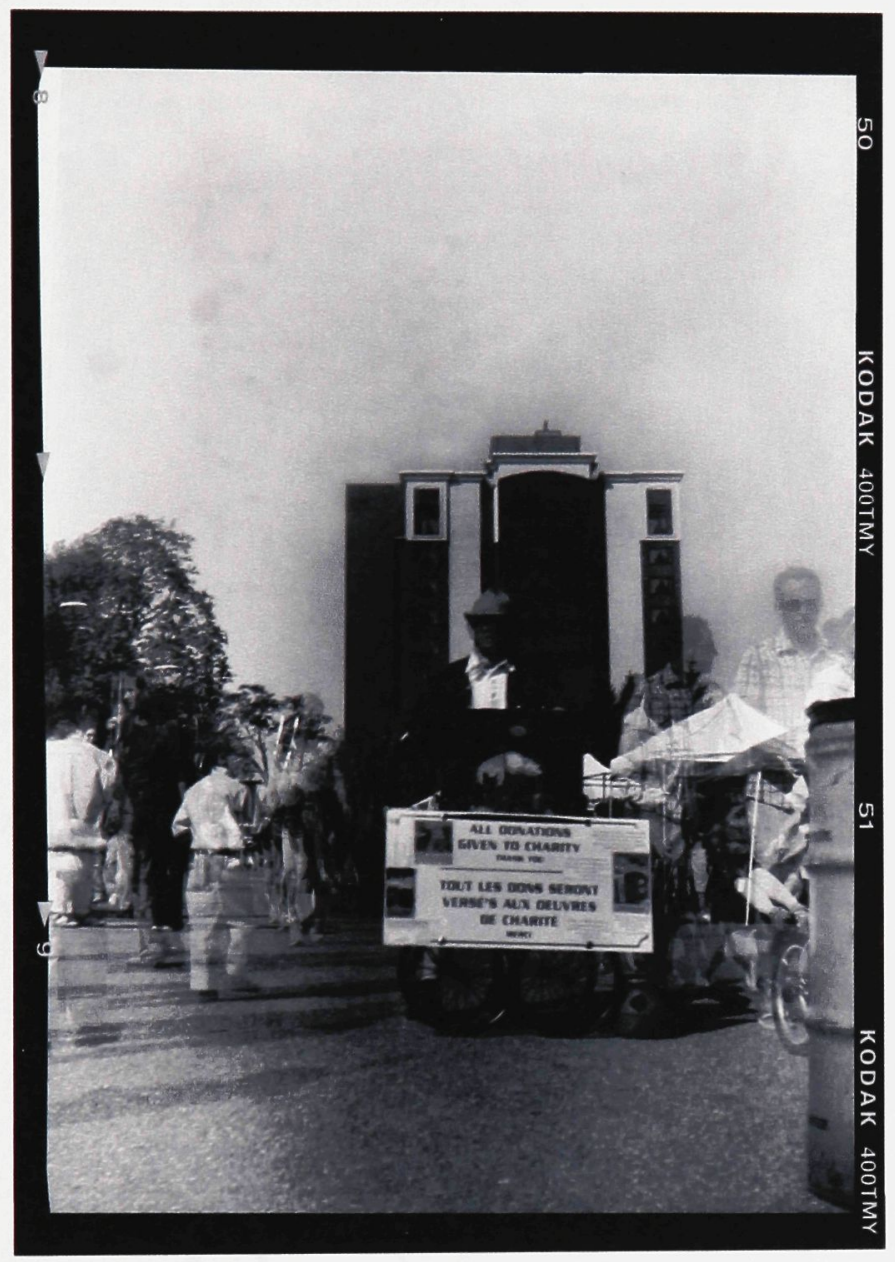

The Entertainer by Author
On an ordinary day, on an ordinary street, two men sit and wait in the shade at a bus stop. One sits on a step both arms burdened with a week's supply of groceries, the other, a construction worker, anxiously waits after an early days end. It is mid afternoon, across the street a car horn sounds as two mechanics push a lifeless automobile out of the shop and onto the street. Both remain almost motionless, only their eyes move as to watch as a sea of pedestrians whirl about them. From around the corner the melody of a classical guitar is faintly heard above the maelstrom of roaring traffic. Here a one armed man sits on a ledge in front of his open guitar case. A young lady with a role of tape and a stack of flyers in her hand pauses from her work for a moment to enjoy the tune tosses a shimmering coin into the case. Without missing a beat the man nods and continues to play, pick in one hand, and a broken coffee mug on the stump of the other. The lady resumes her work posting flyers lamenting the plight of the people of Darfur on the nearby lamp post. The traffic light turns red and the faint moment of peace is interrupted by a school bell signalling the end of day. Through an open door across the alley the sounds of clanking pots and pans and hurried voices as a restaurant kitchen prepares for the dinner rush. From around the corner a group of giggling school children pause to look in a shop window then skip off, careful not to step on any cracks. The light turns green, the roar of a diesel engine is heard followed by the screech of brakes. A bus stops. Both men slip inside, only to be transported to another ordinary street on this ordinary day. 


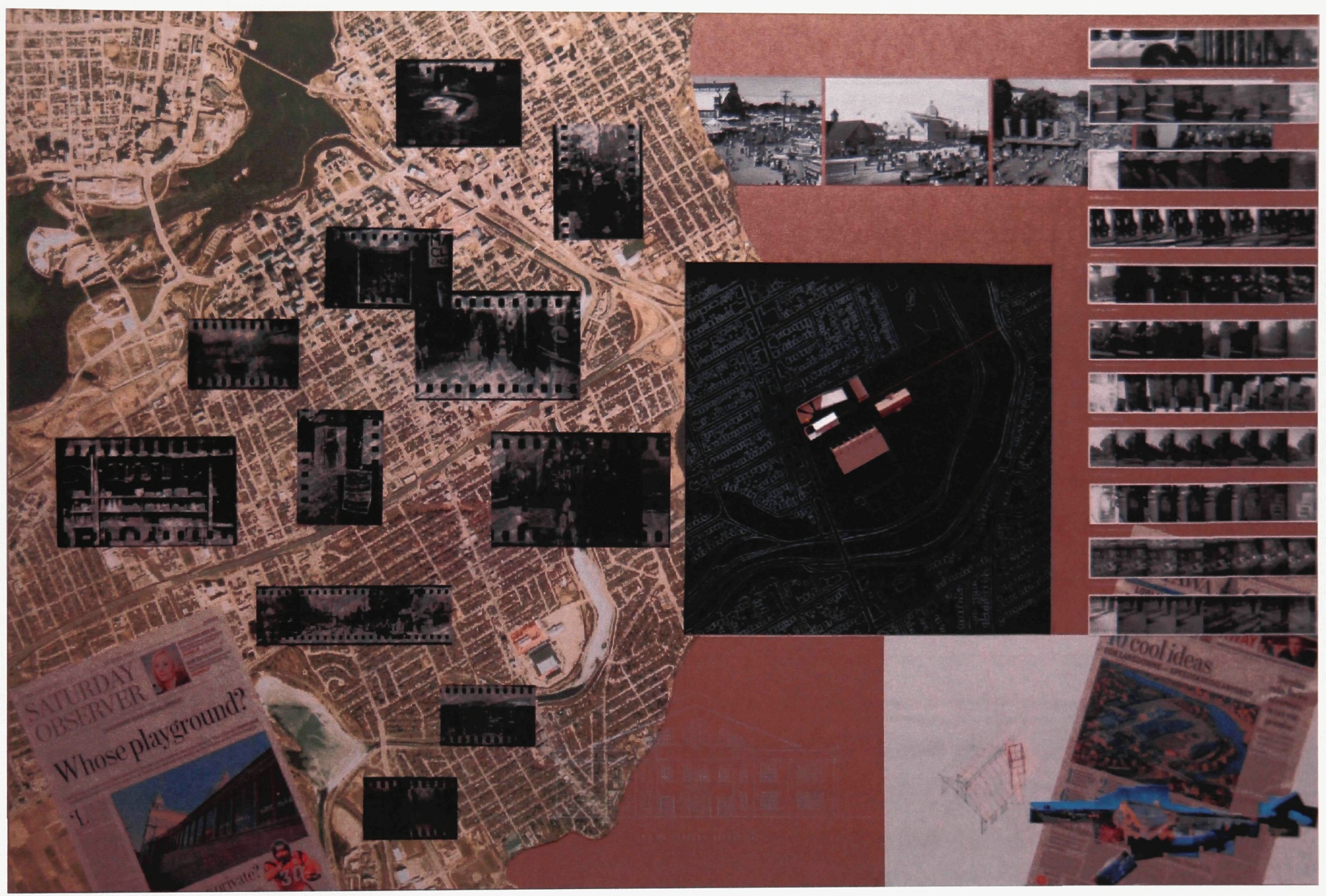

Flâneur Panel

Collaged panel showing map of districts explored by flânerie in relation to the site [highlighted in red], photographic studies and observations, newspaper clippings relevant to the site [obtained on flânerie], site documentation, and site model showing proposed intervention 
On a countless number of occasions through the course of the year, I allowed myself to wander throughout the streets of the city of Ottawa. My flânerie took me to all types of communities and districts within the central core of the city. Armed with a notebook, pen and a 1927 Target-Six Kodak Brownie camera, I ventured into the streets to prove that flânerie was not an outdated form of observing, understanding, and analysing the city in its current state of modernity. As Eisner argued, the true life of the city is on its streets where daily life swirls ${ }^{1}$, the characters, events, and encounters observed there provide a snapshot of our contemporary society, and an almost infinite potential to gain poetic inspiration drawn directly from daily life.

I chose the Brownie camera because it is one of the most rudimentary forms of capturing images. Its lack of settings or options led me to experiment with Benjamin's notion of the colportage phenomenon of space. By taking multiple exposures, or in essence collapsing multiple moments into a single image, the feeling of movement within a three second time frame on the street is graphically reconstructed: business men swiftly passing by in a state of distraction, a crowd eagerly waiting for a stoplight to change, a father and son walking leisurely through a market, or the act of turning from one street onto another. Victor Fournel once wrote of the flâneur before the invention of the hand held camera: "This man is a roving and impassioned daguerreotype that preserves the least traces, and on which are reproduced, with their changing reflections, the course of things, the movement of the city, the multiple physiognomy of the public spirit, the confessions, antipathies, and admirations of the crowd."2 These photographic studies tried to capture the physiognomy of the public spirit and the current state of contemporary modernity of the city. Each image becomes its own graphic story, and if the age old expression "a picture is worth a thousand words" is true than the collapsing of three images must be worth three thousand. These photographic studies are scattered 
throughout the text [ii, iii, iv, $1,4,8,52]$, rather than writing specifically about each one the reader is allowed to act as a flâneur and draw their own conclusions about the apathies, expressions, and emotions depicted in each image.

Through flânerie, subtle changes rhythms, crescendos, and climaxes in the street were observed and recorded. Transit stops were noted as portals transporting citizens from one street to a completely different street of a different time and place. Victor Hugo wrote of the new omnibuses of Paris as roaming platforms from which the indolent flâneur could observe street life from a detached point of view. ${ }^{3}$ From a phenomenological standpoint transit stops and the buses themselves provide a fascinating meeting place where complete strangers paths may cross, each forced into extended silent observation of the other. Transit stops also provide the street with a visual timepiece, a metronome that is not only reflected by the cyclic passing of the bus itself, but felt by the influx of pedestrians into the street. Pedestrians pulsate from transit stops, rhythmically radiating and invading shops and spaces down the street.

The ephemeral and transitory nature of streets was also observed. Streets are the playgrounds of cities. It is the place that citizens and crowds turn to in times of jubilant celebrations, cultural protests and parades. There is something fantastic that is felt by being in the equivocal stage of the street. Children often ignore the safe settings of parks and designated play spaces in favour of crowd filled streets to play their games. Adults turn to streets to unwind in the form of outdoor cafés and patios. The ephemeral nature of street festivals, fairs, and events play on the observers image of the place, tying a memory to a specific time and place, forever altering ones perception of that place.

Streets in essence are a boundary buffer space between buildings that take on multiple functions. The juxtapositions formed between varying programs that define the urban edge create the intensity of spontaneity encountered on the street which intensifies exponentially the greater the juxtapositions are. Markets, like the Parisian Arcades are like a city in miniature. The interstitial spaces between the stalls and vendors act as the theatrical stage set of the street; the merchants and vendors its shops. Spontaneous and chance encounters occur at a hyperactive rate 
accelerated by the diversity of goods offered at stalls adjacent to one another; as in urban streets, the more juxtaposed the programmatic elements adjacent to one another are, the more exciting the spaces between are to encounter. The two markets in Ottawa: the Byward Market, the Westboro Market and Chinatown on Somerset Street West became favourite places as flâneur-architect to observe, imagine and invent. No matter what time of day these places were visited, an active crowd was eagerly perusing though fresh produce, arts and crafts exhibited on the street.

The street forms impromptu social space based upon the random and chance meetings and events that occur there. Columns, porticos, benches and stoops provide moments of pause and social interaction in the urban theatre. Communal participation or shared experience brought on by events both planned and spontaneous provided strangers with a common bond and potential commonalities from which to base conversation or even friendship. Social Space fills up the interstitial voids between programmatic functions feeding off of each other. As Jane Jacobs wrote in The Death and Life of Great American Cities, "The point of the social life of city sidewalks is precisely that they are public. They bring together people that do not know each other in an intimate, private social fashion and in most cases do not care to know each other in that fashion."4

It was during one flânerie that the swap box project was discovered. Swap boxes are interactive, participatory public art pieces, designed and installed by a local conceptual artist by the pseudonym Elmaks. These small, brightly coloured boxes, randomly installed on street corners, vacant buildings, and lamp posts became culminations of my wanderings. People are encouraged to participate in the program by taking a random artifact from the box if they replace it with another artifact. Typically the relics were as random as the swap box locations themselves, ranging from shirt buttons, to small books of poetry, and even vouchers entitling someone to make small talk with a person on the street of their choice. Every time I passed a swap box, curiosity always required me to have a look inside, but what became more interesting was observing how others responded to them. In his online blog, Elmaks presented a 

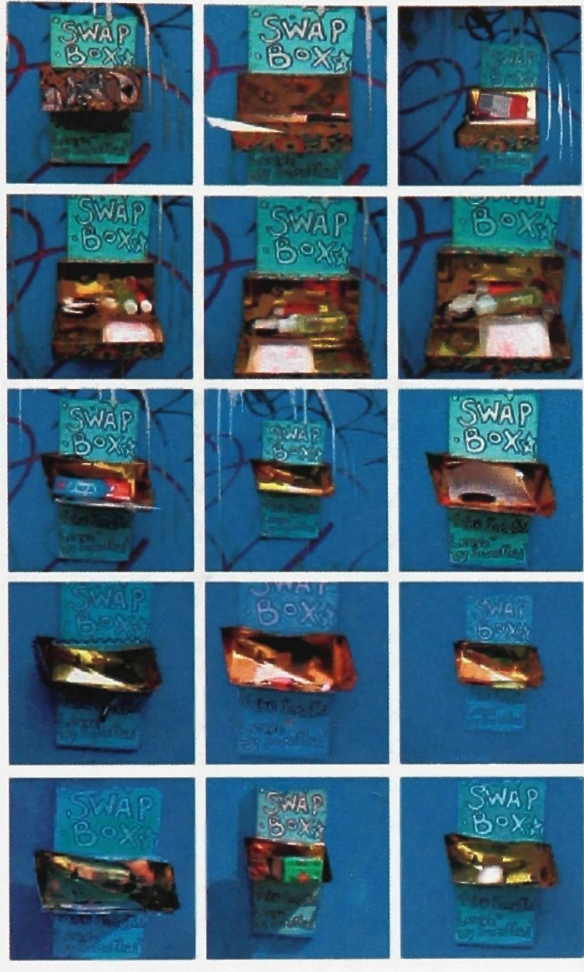

fig. 3
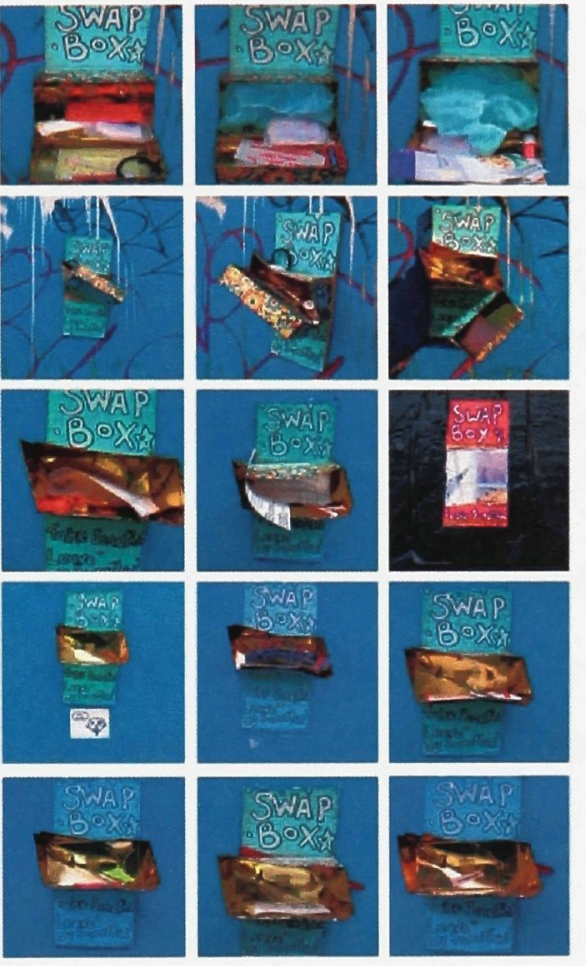

Life of a Swap Box Simon Milligan manifesto of what the swap box project and street art in general should contribute to a community. Swap boxes contribute a sense of beauty, wonder, and an element of surprise to the urban landscape; they create a social destination which keeps people coming back, drawing people's paths together providing a potential meeting place for strangers. ${ }^{5}$ Although flânerie is typically a solitary exercise, Jules Romains once theorized about kinship developed through live, shared, participatory experience which is powerful enough to break through such solitude:

"According to my idea, it is always rather in that way that you make friends with anybody. You are present together at a moment of life in the world, perhaps in the presence of a fleeting secret of the world-an apparition which nobody has ever seen before and perhaps nobody will ever see again. It may even be something very little. Take two men going for a walk, for example, like us. Suddenly, thanks to a break in the clouds, a ray of light comes and strikes the top of a wall; and the top of the wall becomes for a moment, something in some way quite extraordinary. One of the two men touches the other on the shoulder. The other raises his head and sees it too, understands it too. Then the thing up there vanishes. But they will know in aeternum that it once existed." ${ }^{6}$ 


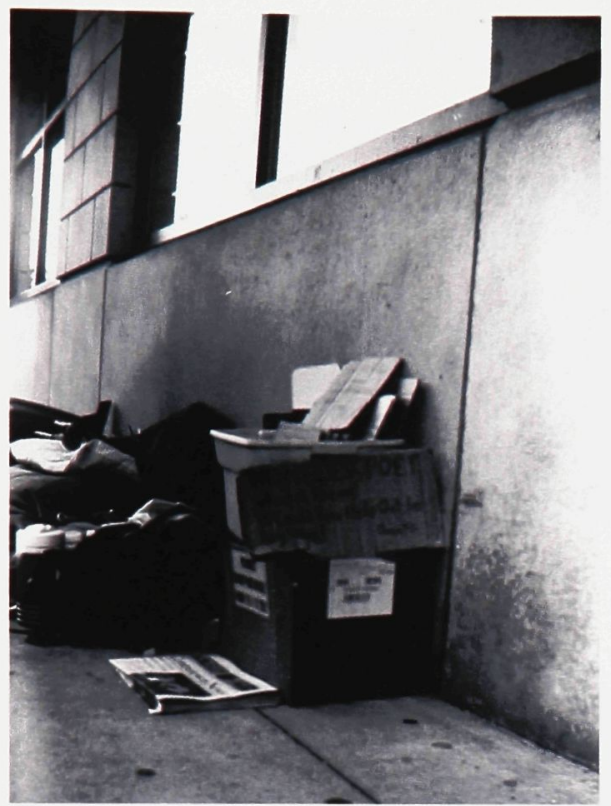

The Homeless Poet's makeshift studio by Author

Many people also depend upon the street as a lifeline, a means of survival.

Buskers and street performers depend on income their acts to survive, while enriching the vitality of street life, creating moments of pause in an otherwise inferno of activity. The flâneur can depend upon street performers to act as markers dictating public spaces and intersections of frequent activity as they usually stake out the best spots from which to perform. It was on one flânerie that I was introduced to a familiar character in and around the Market and Sussex Street, 'Crazzy' Dave Dessler, also known as "The Homeless Poet." 'Crazzy' Dave lives on the streets all year long and writes poetry about what he experience and senses, surviving on the Ottawa Streets. He writes his poetry in coloured marker on pieces of stained scrap cardboard that he finds, busking them in order to make a few dollars to survive.

Through the analytical tool of flânerie, purposely losing myself in different neighbourhoods and communities throughout the city, unearthed hidden truths about how important streets are as public spaces in our modern society revealed themselves. I began to notice that streets serve more than just arterial purpose, but as something multivalent, serving many purposes simultaneously. I observed the street as: 


\section{Street as Transfer Point}

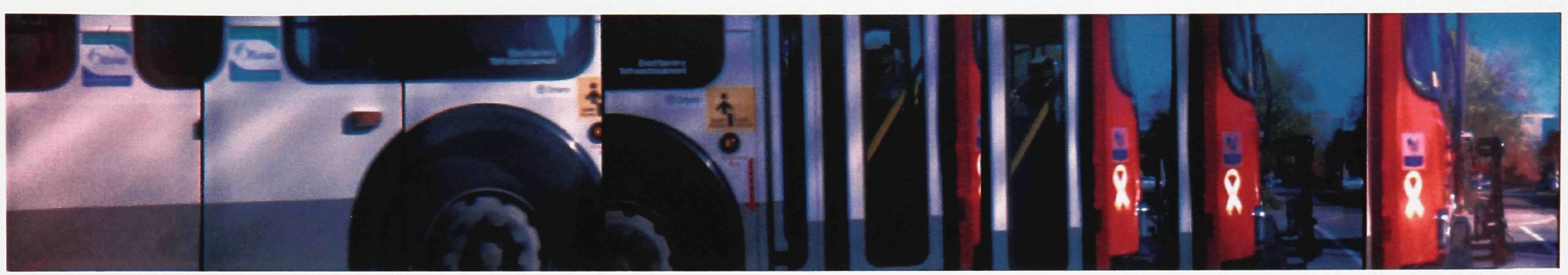

\section{Street as Theatre}

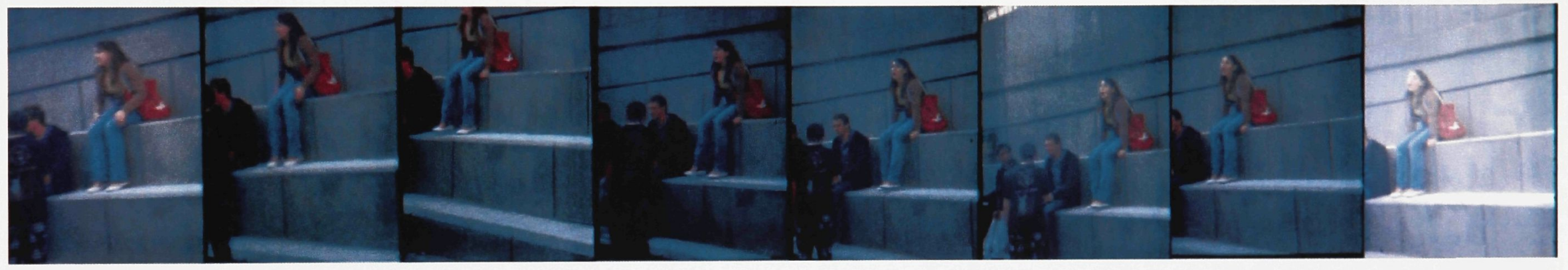

\section{Street as Playground}

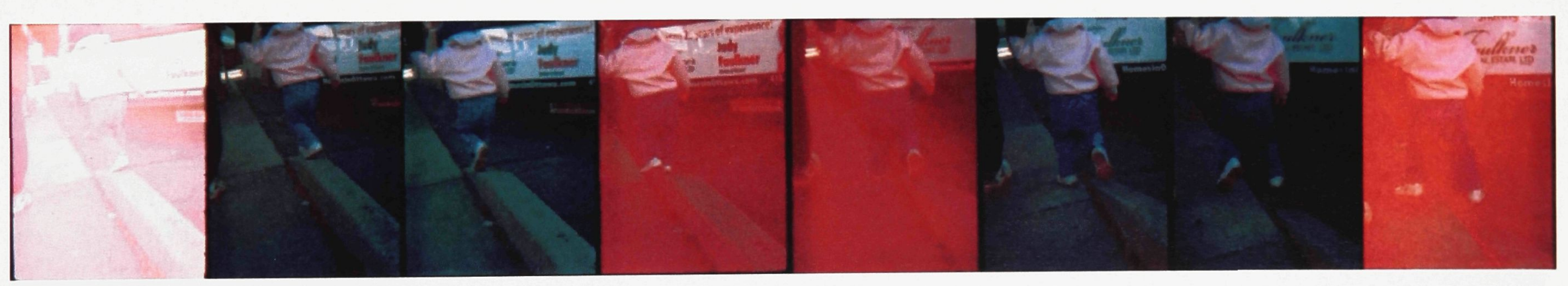




\section{Street as Social Space}

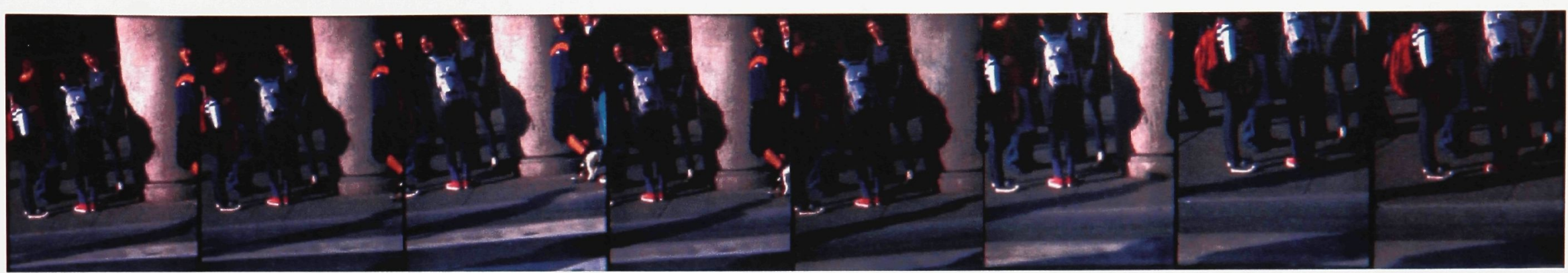

\section{Street as Market}

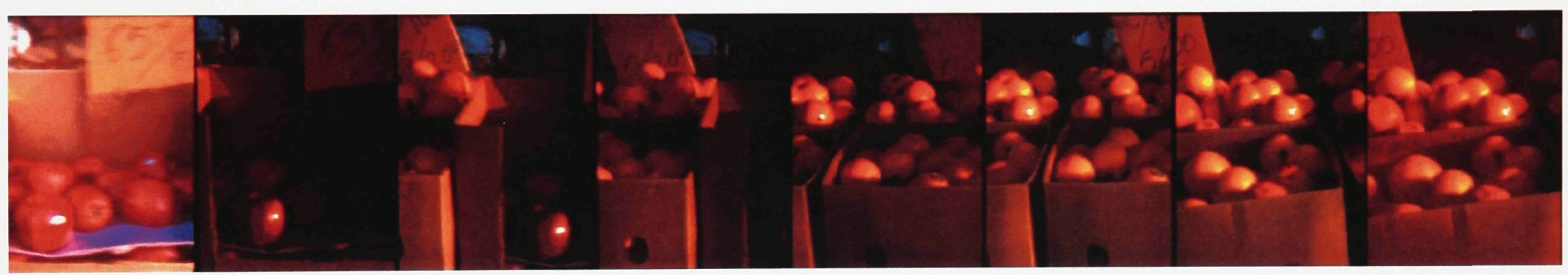

\section{Street as Place of Contemplation}

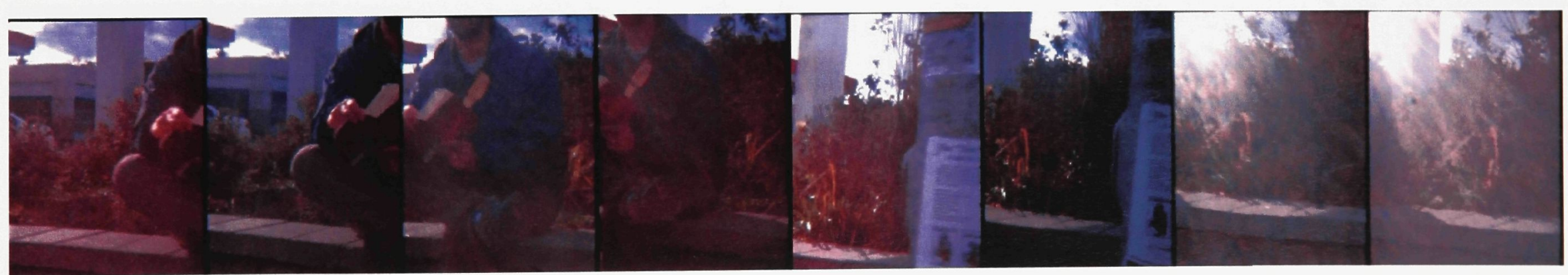


Street as Exhibition

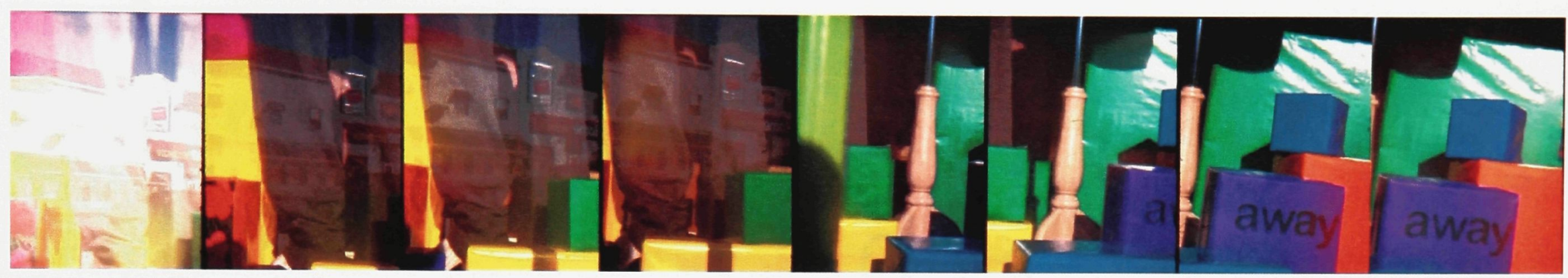

Street as Workplace

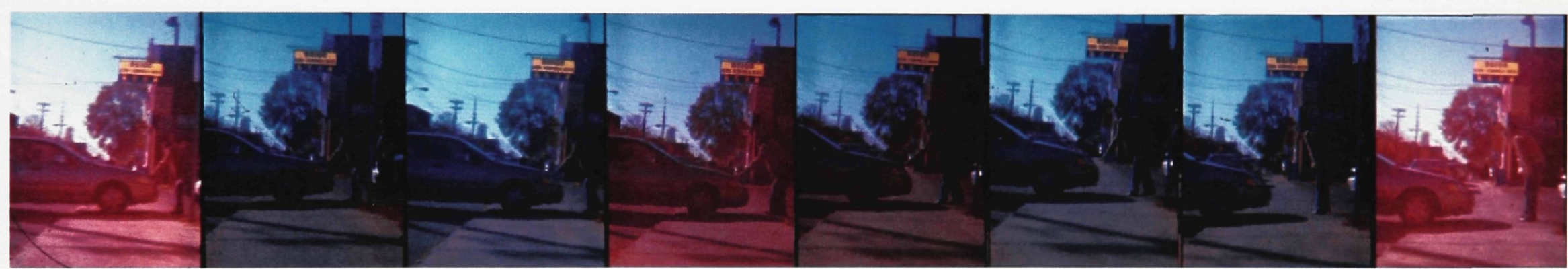

Street as Place for Distribution of Ideas/Media

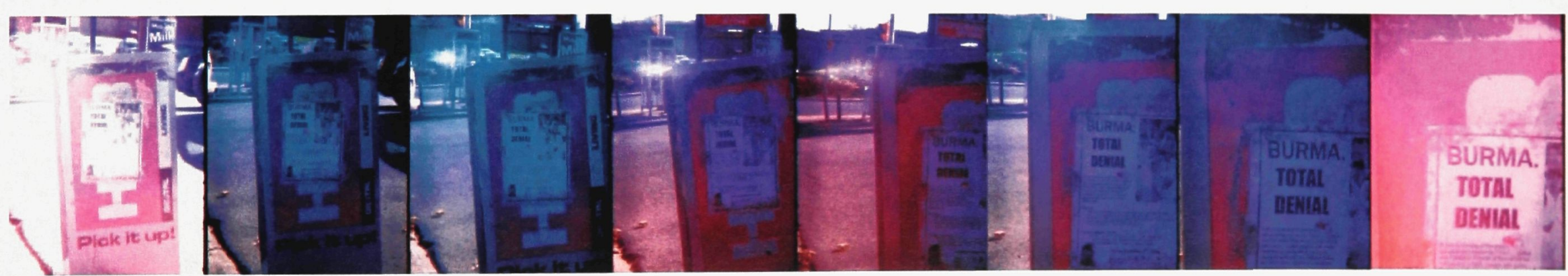




\section{Street as Lifeline}

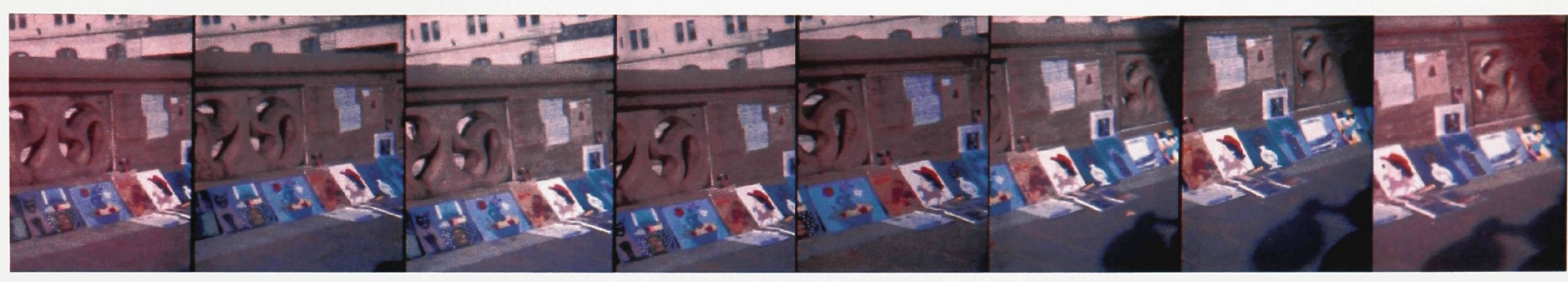

\section{Street: from point $A$ to $B$}

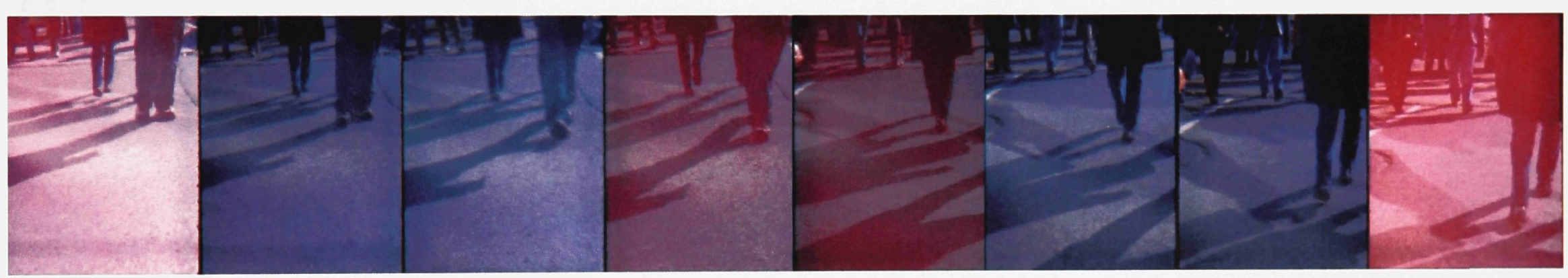




\section{Notes}

${ }^{1}$ Will Eisner, New York: Life in the Big City (New York: W.W. Norton \& Company Ltd., 2006) 3

${ }^{2}$ Walter Benjamin, The Arcades Project. trans. Howard and Kevin McLaughlin Eiland (Cambridge: Belknap Press, 1999) 681

${ }^{3}$ Benjamin, The Arcades Project. 433

${ }^{4}$ Jane Jacobs, The Death and Life of Great American Cities. (New York: Random House Publishing, 1993) 72

${ }^{5}$ Elmaks. Deviant Art. 19 November 2007. 16 August 2008 <http://elmaks.deviantart.com/journal/>.

${ }^{6}$ qtd. in: Benjamin, The Arcades Project. 444

Originally Cited: Jules Romains, Les Hommes de bonne volunte, book 2, Crime de Quinette (Paris, 1932) 175-176 


\section{Conclusion}

The flâneur sees and walks throughout the pages of history; a labyrinthine route from a concept taken and developed by Baudelaire through to Surrealism, adapted by the Situationist International and revamped by the more contemporary Fluxus movement, wandering its way into the digital and cybernetic realm. However, this project is rooted within a hybrid of the Baudelairean and Benjamin philosophy of the flâneur because it is far less grounded in political discourse, but feeds from poetic inspiration and analytical understanding of contemporary culture and modernity through wandering the theatrical streets of the metropolis. Utilizing the conceptual framework of the flâneur as laid out by Charles Baudelaire and Walter Benjamin, the flâneur-architect creates spontaneous event based architecture that encourages social interaction within a broad demographic and cultural milieu. Like the Parisian Arcades that were a new invention of Baudelaire's time, and attracted people of all types to come, shop, and just inhabit, the project designed by the flâneur-architect must also act as bait to lure the masses or characters to the site in order to observe them. The project forms a dialectic between spaces designed through flânerie based research of the city and a theatrical laboratory for new flâneurs to come, wander, and observe. Dynamic programmatic elements derived through an analytical understanding of successful and vibrant communities such as a dance club, intersecting with a market, mixed with a playground and adjacent to a sports stadium provide almost an infinite potential of spontaneous meetings and events to occur in the spaces, or "stages" in between.

By cruising the urban landscape of Ottawa with the sensitivity and reconnoitering of a flâneur, specific moments and events were observed, understood, and translated into an architectural idea. The pavilion for the distribution of ideas birthed out of a moment of observing Green Peace members trying to spread their principles from a stage of newspaper boxes plastered with posters proclaiming other propaganda. The mobile writing/artist studio, although an 
homage to Baudelaire, is also based upon a specific character familiar to the streets of Ottawa, the homeless Poet,

'Crazzy' Dave Dessler, who has been a regular fixture in the Market and on Sussex Street writing hundreds of poems on scrap pieces of cardboard about his experiences and emotions felt living on the streets. The acoustic music stage, sited within a key corner of the project adjacent to the outdoor café and transit stop, provides a place for a street musician to play and sing; responding to the familiar character of the one-armed guitar player who is a frequent fixture along Bank Street providing a heartening service at a nominal cost. The gallery reacts to moments of curiosity provided through installation artist Elmaks and his Swap Box Project. Vistas from above the market and theatre play with the duality of being both an observer as well as a participant in the public spectacle yielding curious views but putting oneself on exhibition. A playground grew out of the simple act of a child walking carefully along a curb, and an amphitheatre which functions as a place to sit, socialize, and observe the market out of the many stoops that line the streets of Centretown; while the metronome bus stop reacts to the cycles, tides, and ebbs of pedestrian activity on the streets dictated by the cyclic movement of the buses themselves. By observing the spontaneous theatrics of the city and its citizens, the crowd, the flâneur-architects generates an architecture that responds to the analytic needs of the city while poetically providing new opportunities for encounter and play.

Flânerie not only inspired the spaces designed, but it affected the mode of representation of the project as well. Standard pragmatic architectural representation in the form of plans, sections, and elevations, although necessary at the time of design only delineate a precise scientific representation of the space. The graphic story as outlined in "An Afternoon at the Market" [p.8] provides an opportunity to inhabit the spaces and imagine the types of potential encounters and spontaneous interaction that could occur there. Experimenting with the Colportage Phenomenon of Space adds another element to the mode of representation, the element of time; as an observer of these images one can begin to sense movement and emotion of the characters that inhabit them, and like the flâneur, from these clues, deduce 
a story. The graphic story is an assemblage of fragments that piece together a whole, much like the experience of the flâneur.

Flânerie as an analytical tool and poetic generator is a relevant practice for architects as a means of understanding social and spontaneous discourse of our contemporary society. As society continues to hurl ourselves deeper into the digital realm, we are losing our ability to make physical connections with those that surround us. As architects who realize this downfall, it is important to observe the events of everyday life in order to design spaces for the community that embraces them. By wandering the communities that surround the site with the sensitivity of a flâneur, the flâneur-architect is able to distil from the collective, spaces that not only respond to the events observed, but provide a seed from which new spontaneous interaction and events can grow. City streets, these intimate democratic spaces of play and theatre, provide the flâneur-architect with an almost infinitely inspired potential to create places that reinvigorate a sense of community within the city. 


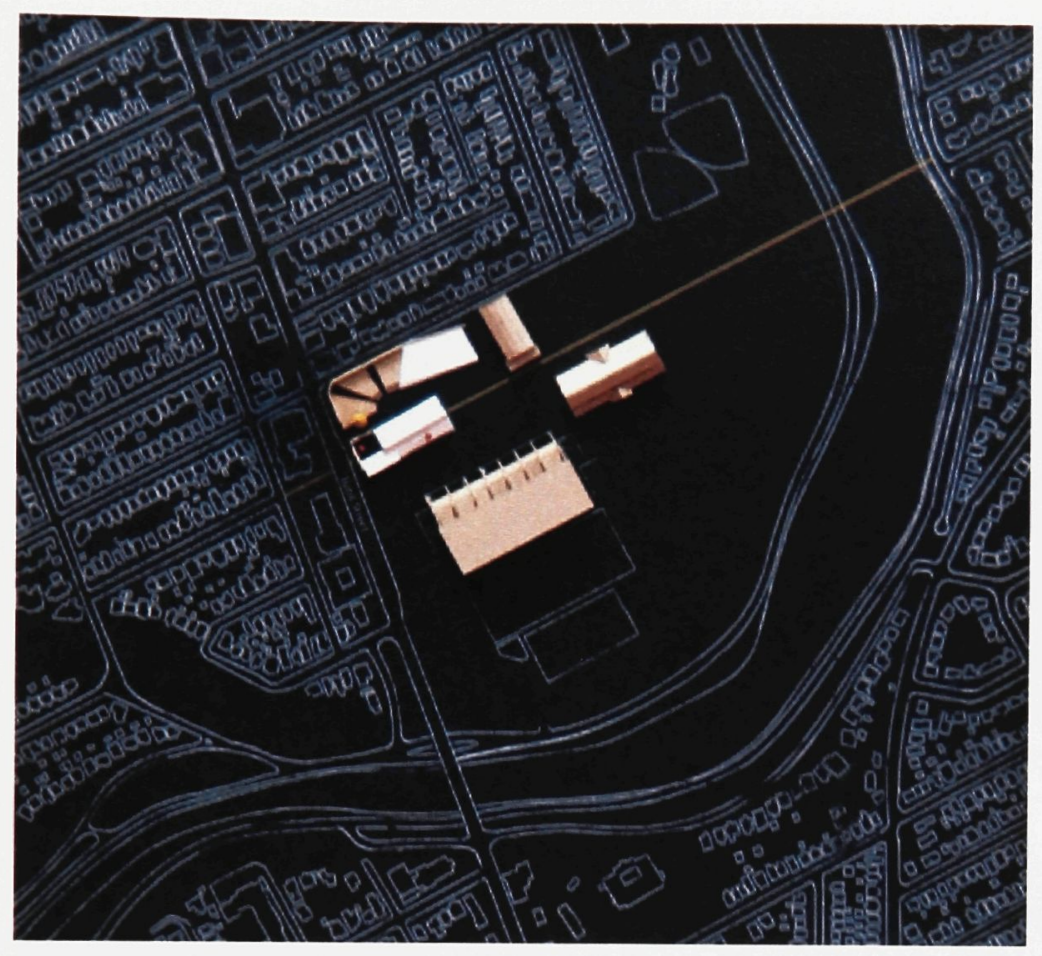

\section{Appendix}

\section{Project [arena of the flâneur]}

Site: Lansdowne Park, Ottawa, Canada

Unlike the exhibition grounds of Paris in the $19^{\text {th }}$ century that were assembly places of the crowd seeking out new capitalist merchandise, and a familiar domain of the flâneur; the exhibition grounds of Ottawa, known as Lansdowne Park, largely remains a barren, desolate asphalt desert. Although the site sits in a fairly active community in Ottawa named the Glebe and is bounded by Bank Street, Holmwood Avenue, and the historic Rideau Canal waterway, it remains predominantly abandoned by the crowd; only visited a few times a year when the Super EX, a spinoff of the Upper Canada Exhibition comes to town in late August, or a few times during the course of the year when sporting events occur there.

The site, since initially being carved out of the forest has always been a place of exhibition. In 1868 the grounds were acquired by the Ottawa Agricultural Society for use as a fairground. At that time the site had been placed well beyond the city limits, now is completely urbane. With the success of the agricultural fair, the site was rebranded in 1888 as the Central Canada Exhibition focusing on the agricultural, industrial, and sporting sectors. Since its birth, the grounds have been home to many spectacles such as pantomime and acrobatic acts, as well as the first use of electricity 
CENTRAL CANADA EXHIBITION, LANSDOWNE PARK. OTTAWA

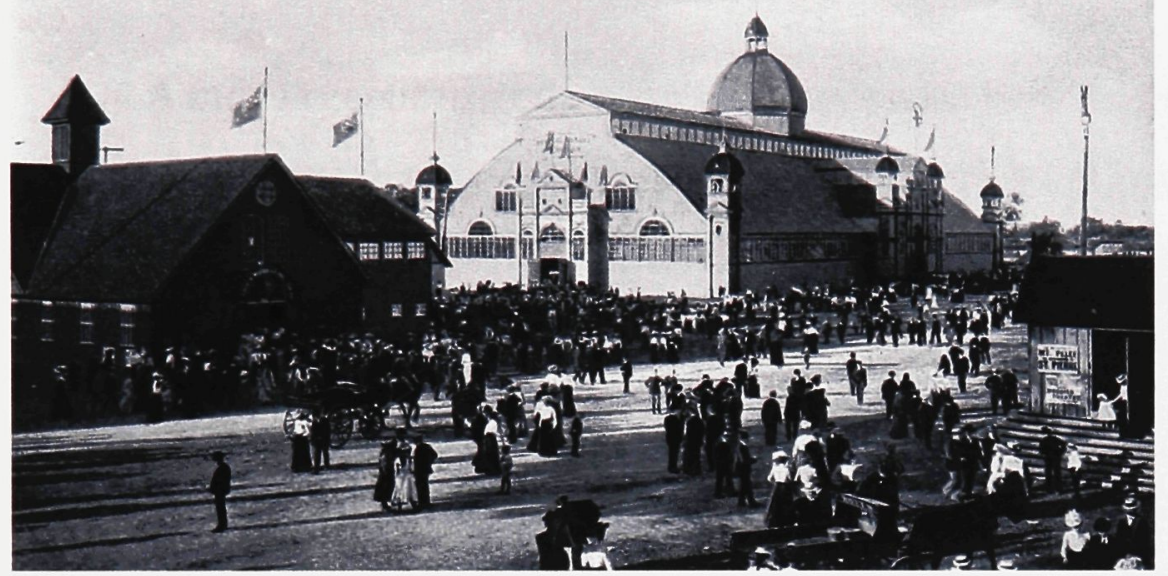

fig 4

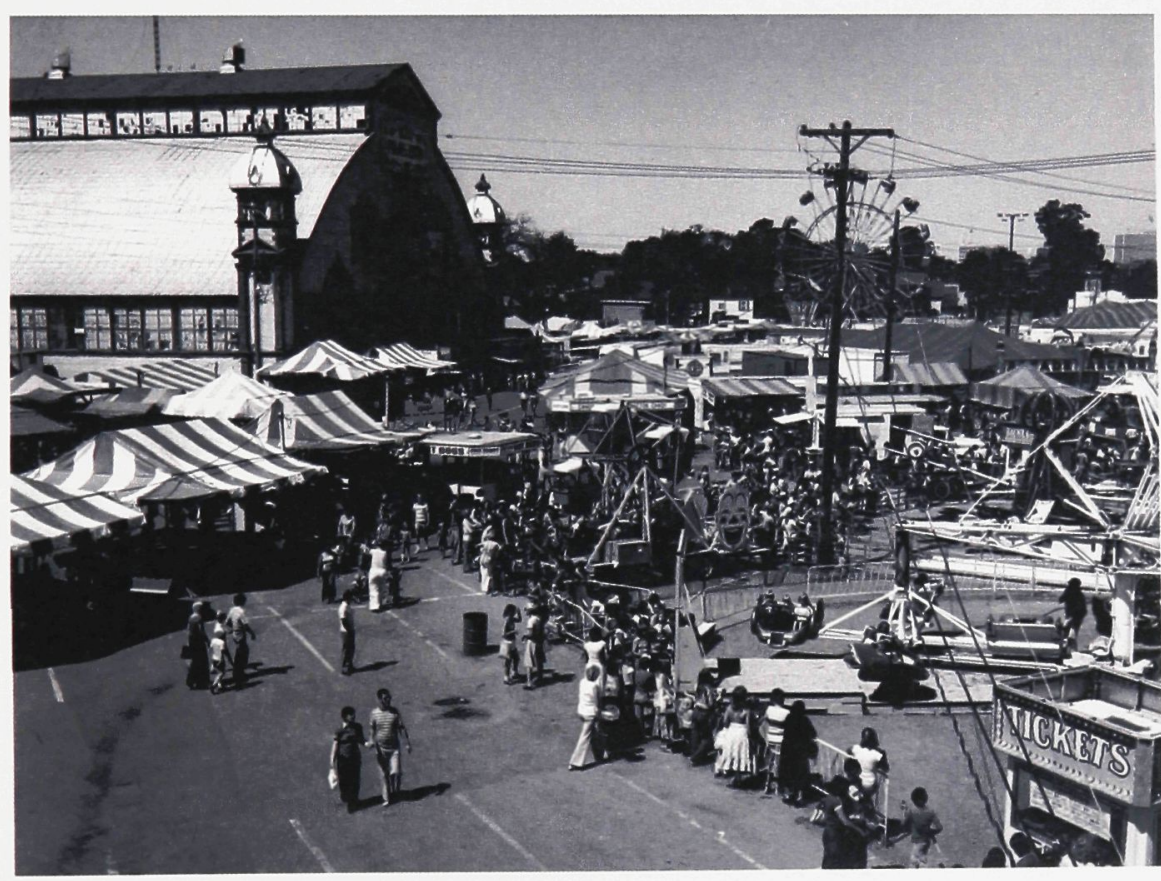

fig 5 in Ottawa, promoted by the owner of the Ottawa Electric

Company, Thomas Ahearn. In 1889 the exhibition gained a great deal of publicity with the stunt performed by daredevil Professor Baptist Peynaud who jumped off of a 150 foot tower onto a safety net in front of a crowd of 20,000 spectators which was a considerable amount since the population of the city at the time was only 44,000 . In 1890, the grounds were renamed Lansdowne Park after the Marquis of Lansdowne who served as Governor General from 1883 to $1888 .{ }^{1}$

The major dominant use of the grounds has been for sporting events, primarily professional spectator sports. The Aberdeen Pavilion, which was built in 1898, was home to a skating and curling rink and a Stanley Cup playoff hockey game was even played there. Professional baseball, football and horse racing have graced the site since the beginning of the $20^{\text {th }}$ century. The original 1909 grandstand was replaced in 1967 with the current 32,000 seat Frank Clare Stadium and Civic Centre, which currently is still home to the Ottawa 67's OHL hockey team and Ottawa Renegades (formerly Ottawa Rough 
Riders] CFL Football team. Recently, the stadium was also put on the world stage as one of the host venues of the Under-20 FIFA World Cup.

A more recent introduction to Lansdowne Park is the Ottawa Farmer's Market, a rebirth to the agricultural roots of the grounds with over 100 vendors selling fresh local goods ranging from fresh fruits and vegetables, meats, cheeses, to baking, and arts and crafts. The Farmer's Market, which currently operates out of the northwest parking lot, is looking for a permanent home. This project looks to expropriate Howick Hall [more recently named the Coliseum], an original 1926 exhibition building on the grounds adjacent to where the farmers market currently operates as a permanent home for the farmer's market, and as an attraction for both the crowd and flâneur. The project only consumes an underutilized corner of Lansdowne Park, it is intended that the rest of the site can still be used for the Super EX Fair, festivals, and sporting events adding drama and ephemeral experiences to the site.

Notes

${ }^{1}$ John Leaning, The Story of the Glebe. (Ottawa: M.O.M Printing, 1999) 42 


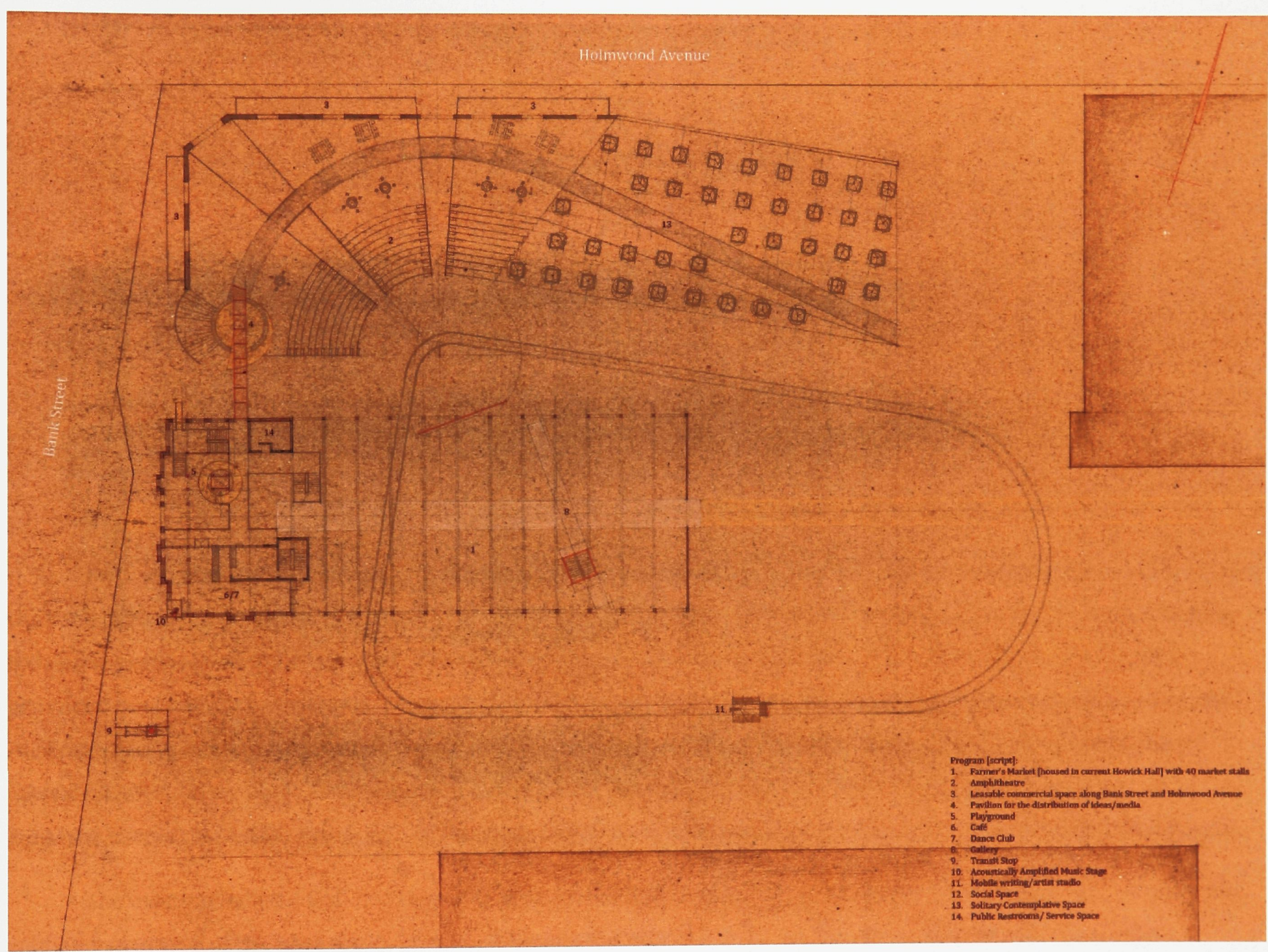

Plan 


\section{Program Description}

Program [script]:

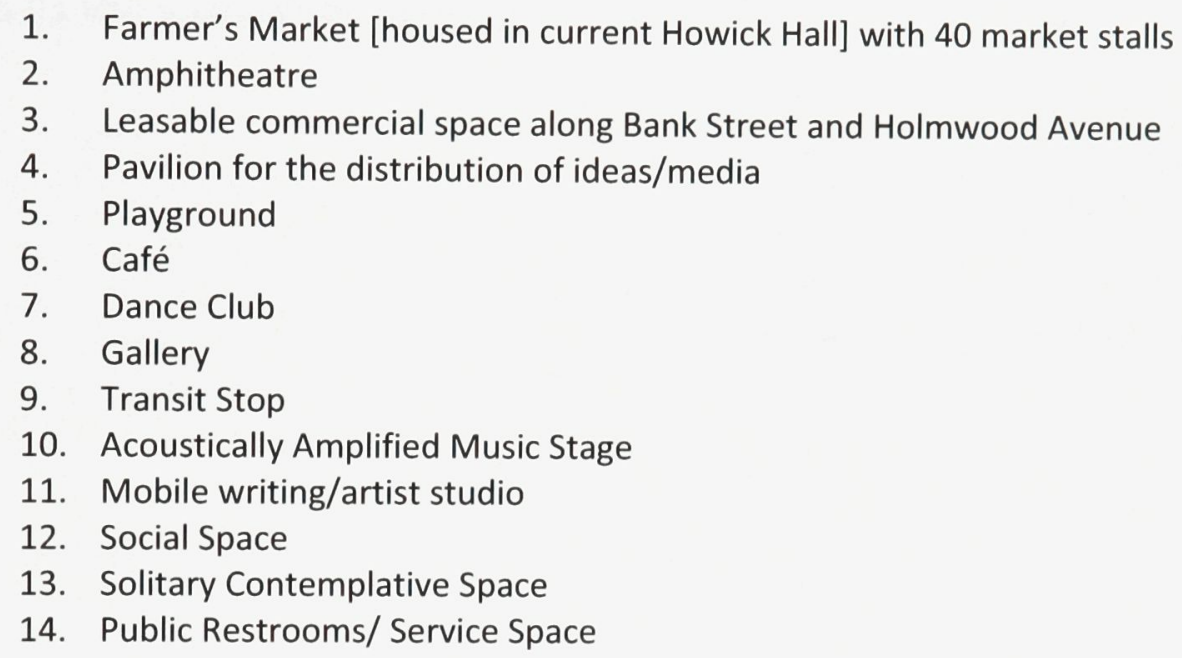

Two main pedestrian paths set up a dichotomy within the project: the path of the crowd [point A to point B] and the path of the flâneur [point A to point B by way of point C,D,E etc.] The path of the crowd bisects the market linking the communities west of Lansdowne Park with the communities on the east side of the Rideau Canal by way of a proposed new pedestrian linkage. The path of the flâneur links the interstitial spaces, the scenes of spontaneous and random encounters set up between the proposed new programs and follies, providing observation grounds for the flâneur. These spaces do not frame events, but allow for interaction and spontaneity to program themselves as a constant fluctuating relationship akin to the streets of the urban theatre, not detracting from the flâneur's imagination.

The existing Howick Hall is stripped of its essentials; all that remains is the brick walls of the front portion, the roof and structure of the back arena portion. Contained within the front brick walls is the play space: the cafe, 
nightclub, playground and circulation. The open air market space contains 40 market stalls and a gallery/observation space contained within the truss structure above with points protruding through the roof in the north and south sides for observation of the site at large. Placed in and around the Howick Hall are the follies, inspired by the flânerie-based research of the street, linked by the path of the flâneur. 

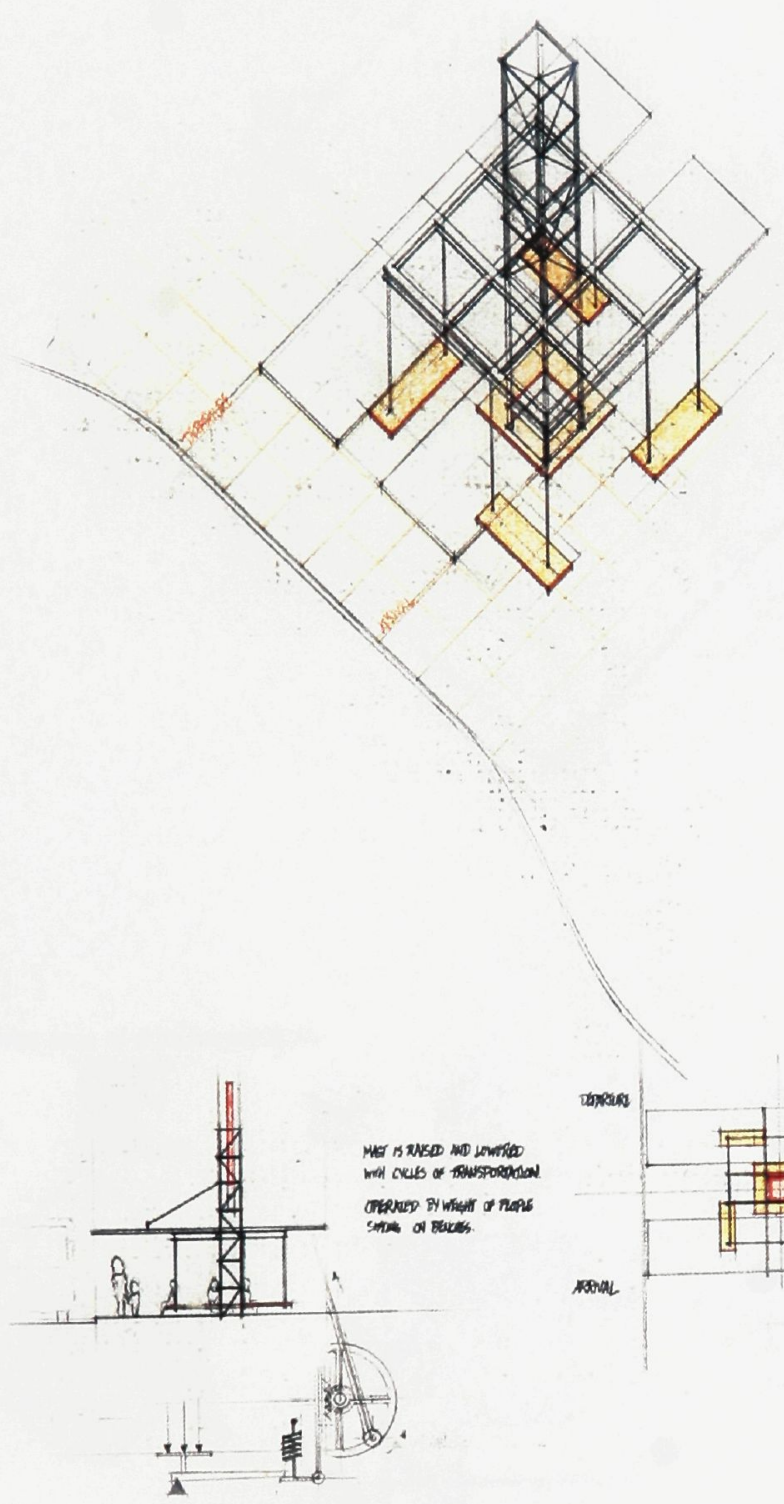

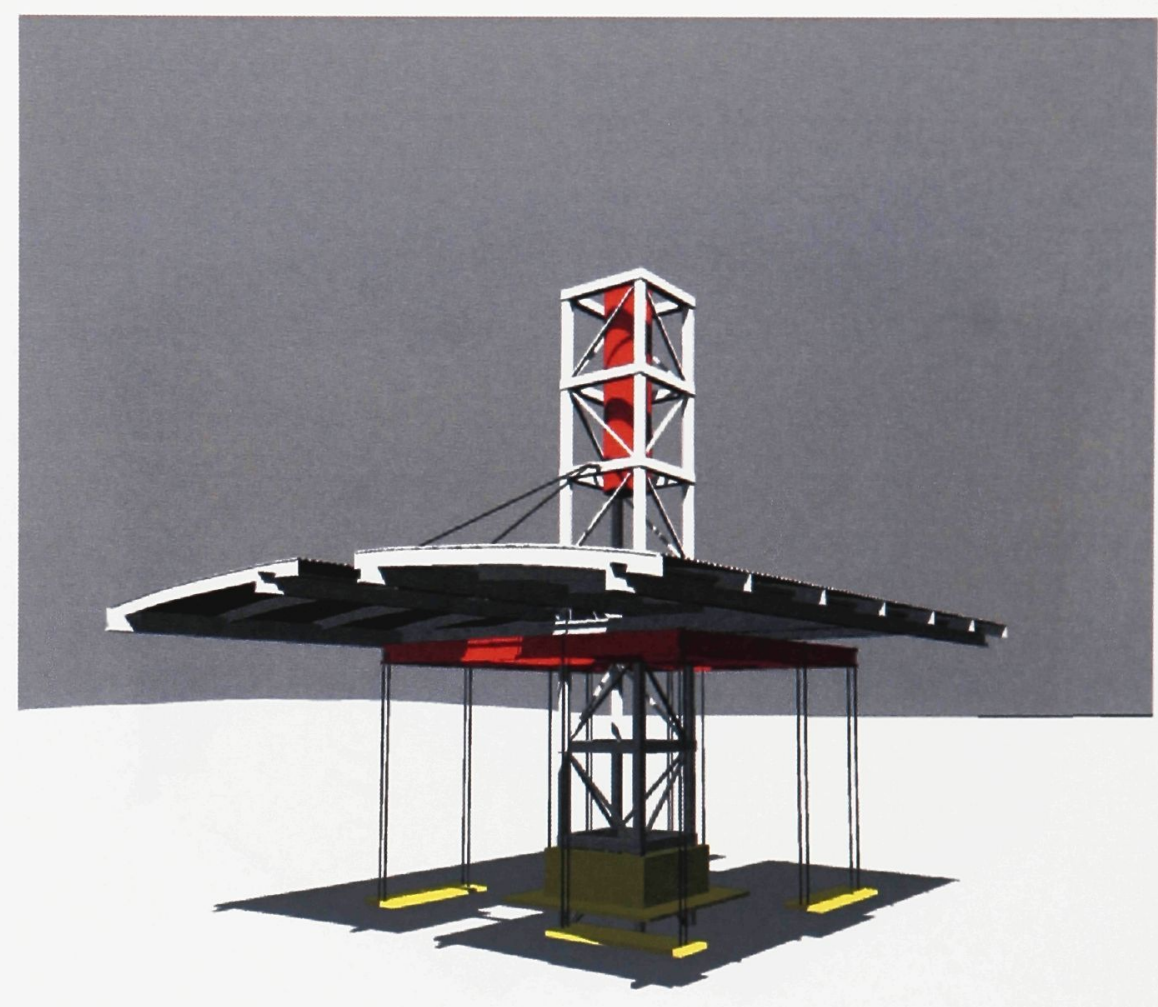

\section{Street as transfer point: Transit Stop}

Transit stops are metronomes for the street, they set the rhythmic pace of pedestrian traffic that pulsates from the stop and diffuses down the street. The bus stop designed for the site takes advantage of this phenomenon by incorporating a simple spring scale device that when the seats of the stop are loaded, the mass of the commuters raises a mast. The mast is then lowered once the bus arrives and the crowd [commuters] have arisen from their seats. A duality will be set up between the two transit stops, one on either side of Bank Street, with each mast continually in flux. 

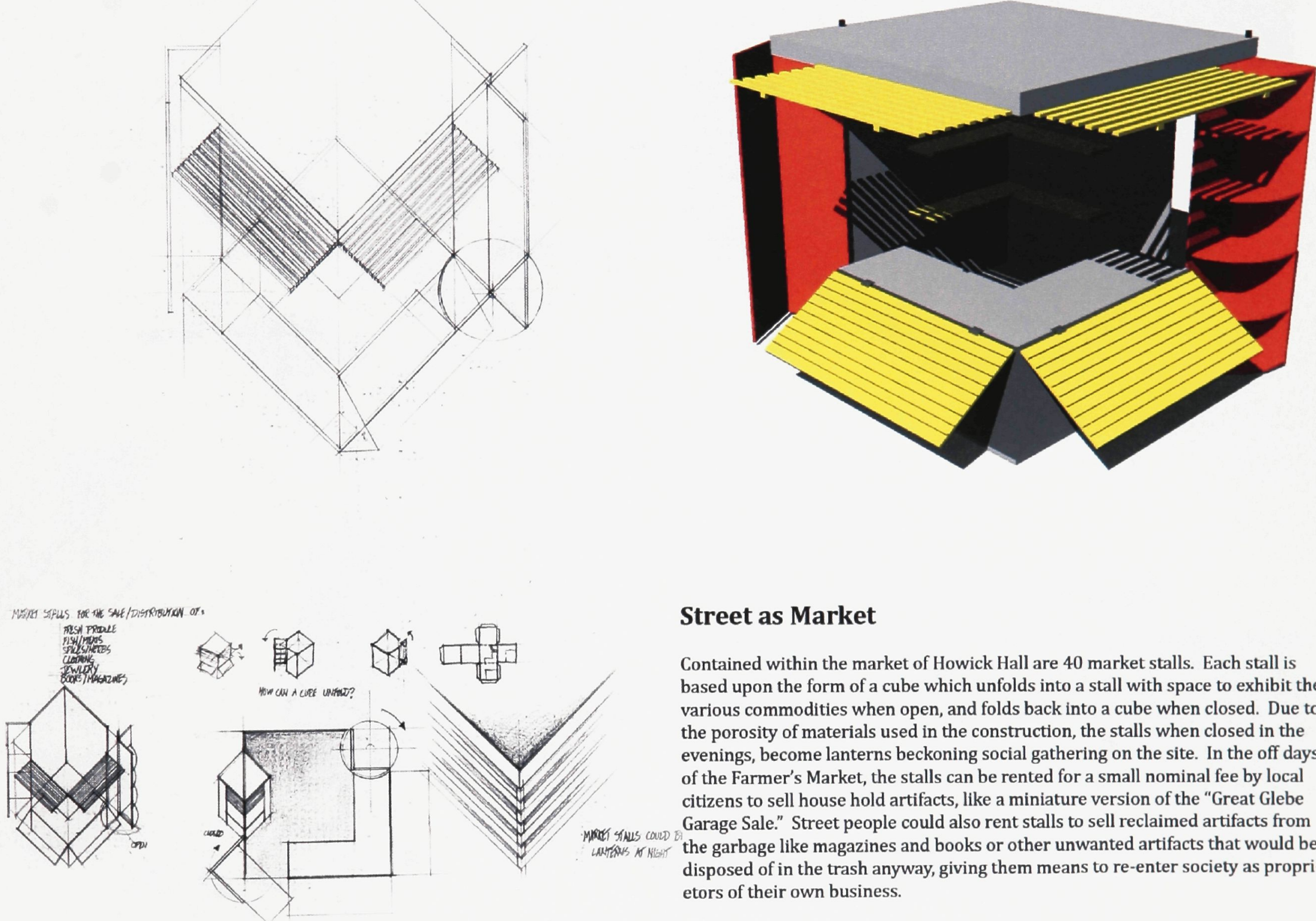

\section{Street as Market}

Contained within the market of Howick Hall are $\mathbf{4 0}$ market stalls. Each stall is based upon the form of a cube which unfolds into a stall with space to exhibit the various commodities when open, and folds back into a cube when closed. Due to the porosity of materials used in the construction, the stalls when closed in the evenings, become lanterns beckoning social gathering on the site. In the off days of the Farmer's Market, the stalls can be rented for a small nominal fee by local citizens to sell house hold artifacts, like a miniature version of the "Great Glebe Garage Sale." Street people could also rent stalls to sell reclaimed artifacts from the garbage like magazines and books or other unwanted artifacts that would be disposed of in the trash anyway, giving them means to re-enter society as proprietors of their own business. 
STREE AS MENS OF UVE
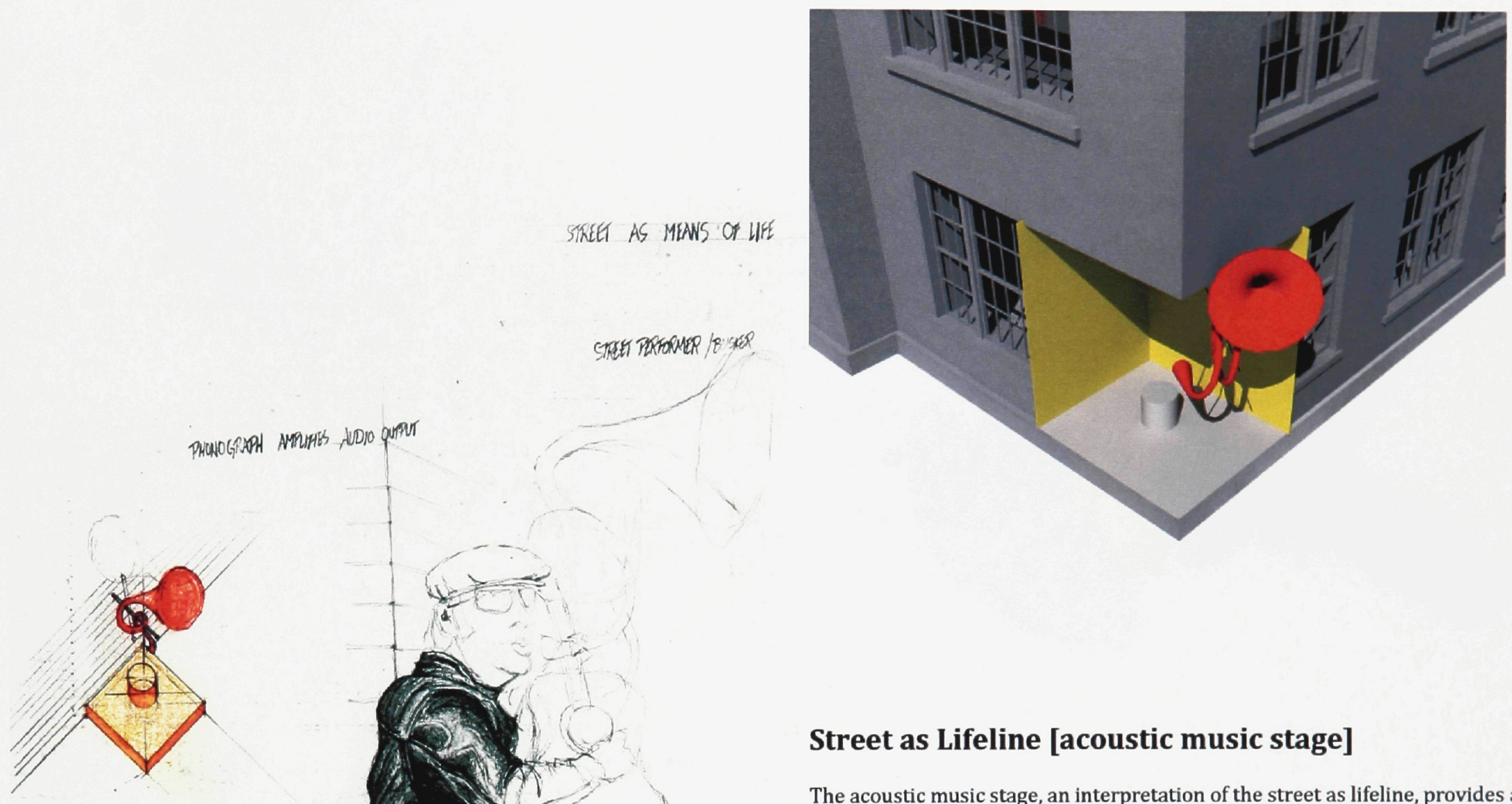

\section{Street as Lifeline [acoustic music stage]}

The acoustic music stage, an interpretation of the street as lifeline, provides a sheltered space for a street musician to play and sing. Located in the southwest corner of the Howick Hall, it has been designed to project music onto the street and transit stop, providing a phonograph inspired acoustic microphone from which to sing into. A second interpretation of the street as lifeline is the ability of a street person to rent a market stall on the off days of the market in order to sell reclaimed artifacts from the city trash like books and magazines. This idea has been adopted from the book Sidewalk which is filled with observations and studies of the street vendors on Fifth Avenue in New York City by sociologist Mitchell Duneier, as a way of helping street people reintegrating back into society and through proprietary necessity help them to rehabilitate themselves. (Dunier) 


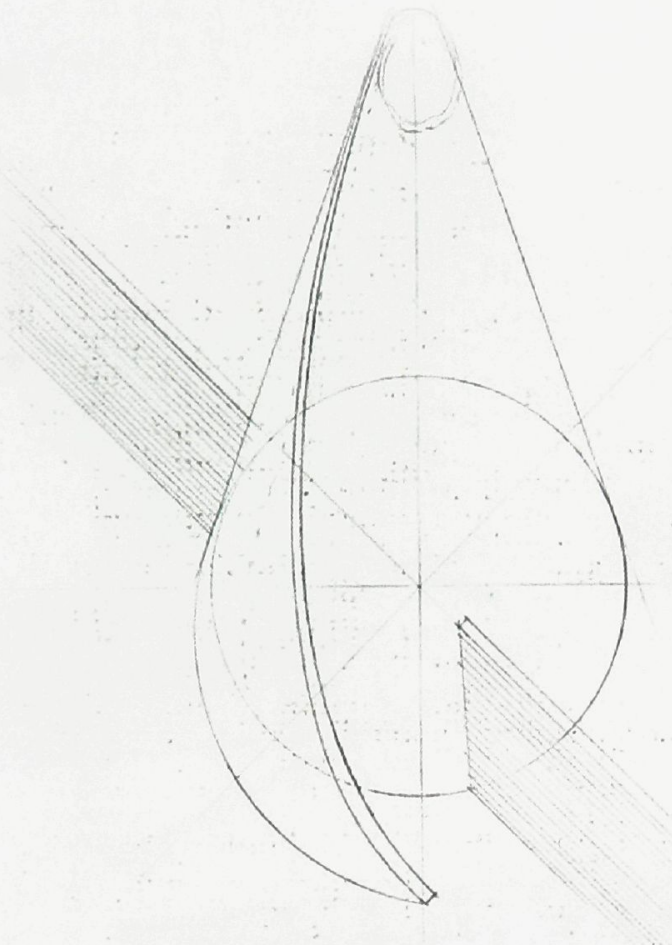

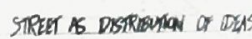
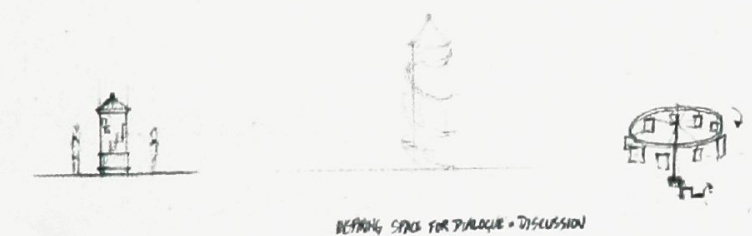

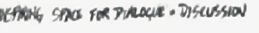

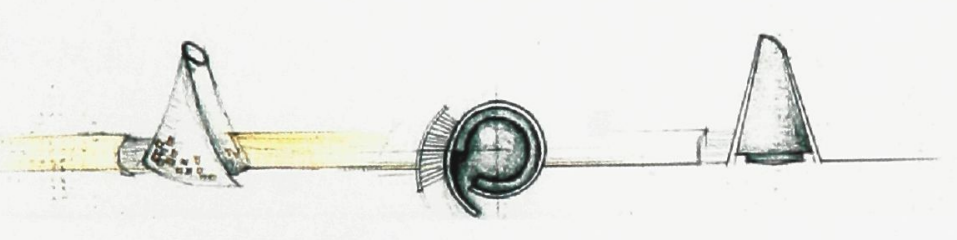

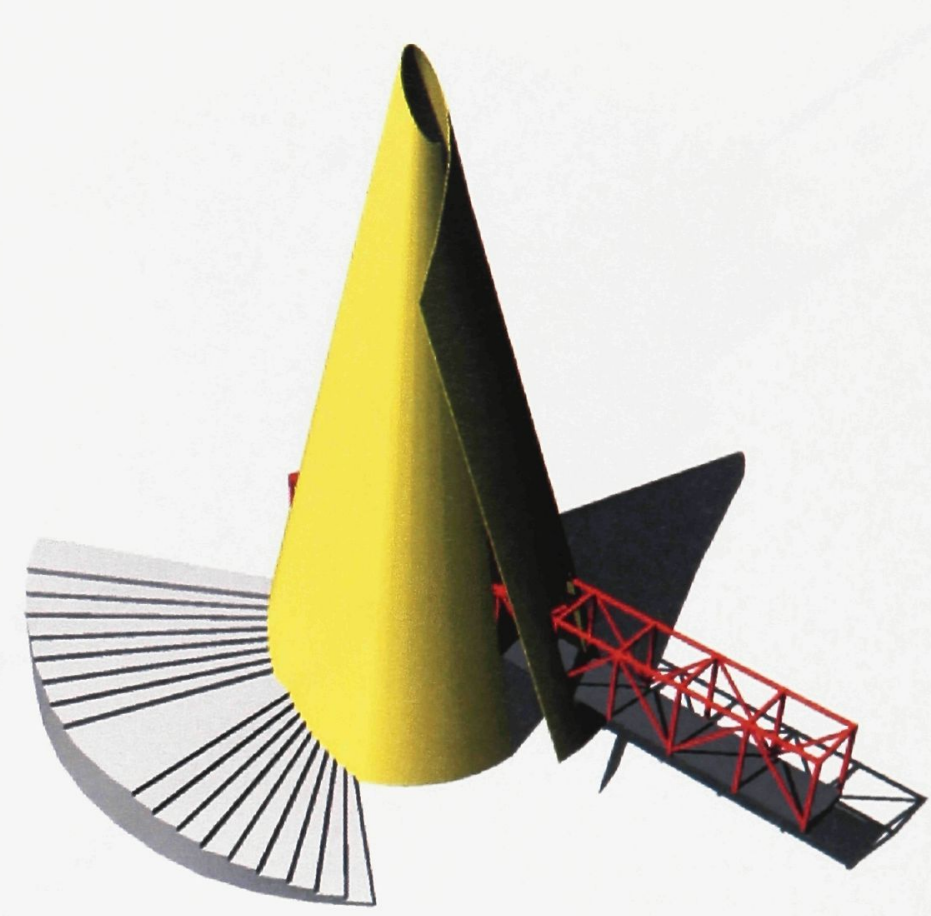

Pavilion for the Distribution of Ideas

A bridge links the park space with the market building by way of the pavilion for the distribution of ideas. This pavilion, a large conical structure that is truncated at the top pays homage to mans ability to think and reason. Inspired by the street kiosks as a place to post upcoming events or distribute propaganda, the entire facade is a bulletin board for which to attach ideas/media while the interior contains a small circular discussion space with a large oculus illuminating it from above. 

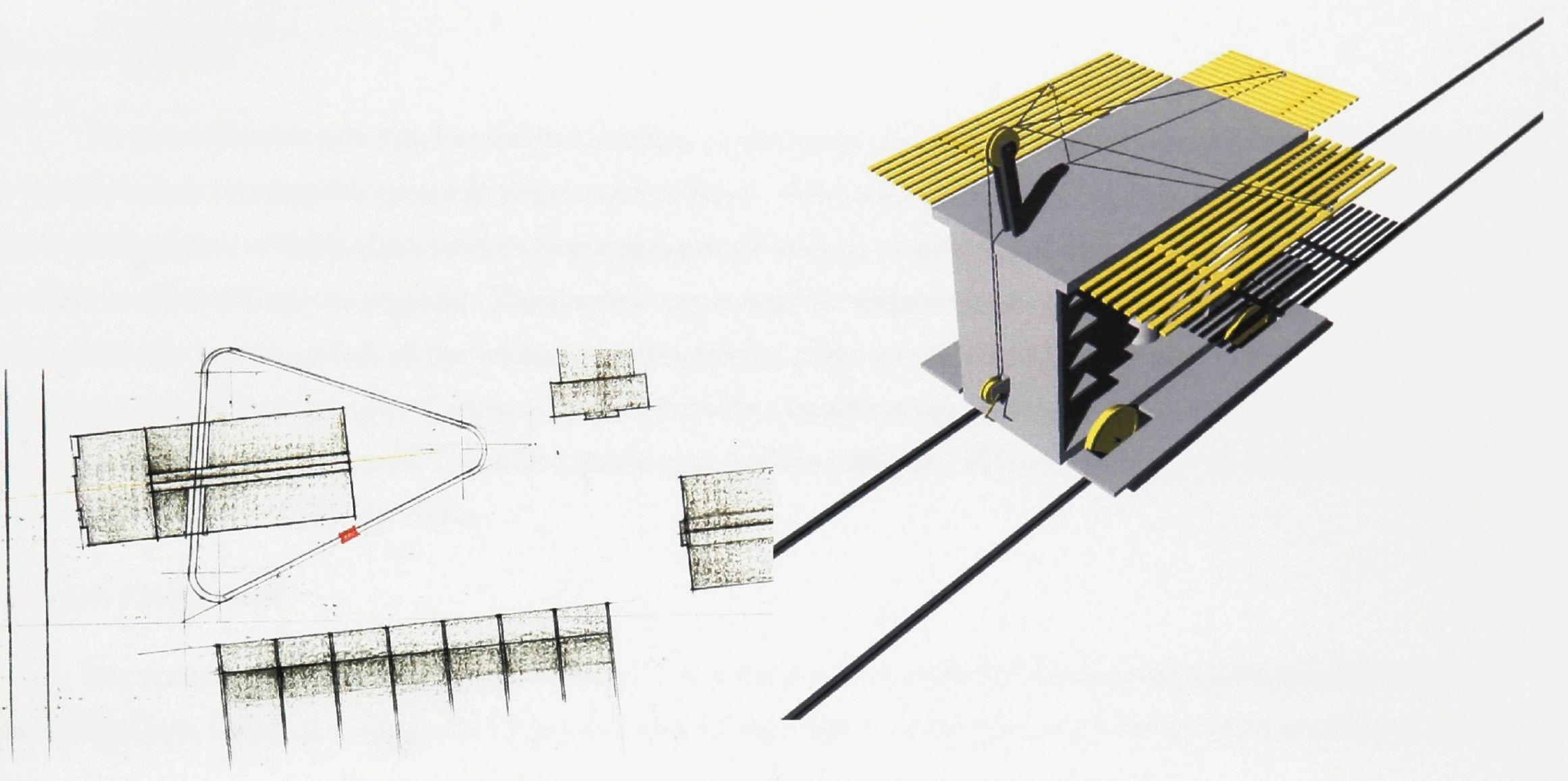

\section{Mobile Writing/Artist Studio}

A track, recessed into the hardscaped surface of the site, cuts through part of the market, and circumnavigates the rest, travelling through the stage of the amphitheatre and the plaza between the market and the stadium. On this track runs the mobile writing/artist studio. In this studio, local flâneur-artists from the community are invited to come and draw inspiration from the crowds to motivate their work, a tribute to Baudelaire and the Homeless Poet of Ottawa. If the flâneur-artist wishes to move to a different part of the site, he or she must seduce help from the crowd in order to push the mobile studio wherever the flâneur-artist wishes to go. Finished works are then displayed in the gallery. 


\section{Street as Theatre}

An amphitheatre juts into the market building on the north side with a large projection screen which also acts as a proscenium framing the spectacle of the market below. The current Sylvia Holden Park which occupies a small space at the corner of Bank Street and Holmwood Avenue is moved vertically one story, to make room for three new leasable commercial spaces at grade. These spaces are meant to compliment the market by offering goods that are not offered for sale in the market, all the while enhancing the life of the street. Table top skylights in the park above both illuminate the commercial spaces below as well as provide a visual connection between the two spaces. Public balconies accessed from the park space look down onto the streets below, offering a vantage point from which to observe the theatricality of the street.

\section{Street as Playground}

The notion of the street as playground has been interpreted as a duality between the adult and child's form of play. Contained within the original brick walls of the Howick Hall is a playground circulation space, a café, and dance club.

\section{Street as Exhibition [gallery]}

The gallery, situated in the truss structure above provides space for the flâneur-artist's work to be exhibited and provides inspiring views to the crowd and the exchange of commodities below. The gallery takes advantage of the existing clerestory windows that run along the peak of the roof structure for illumination. The gallery also provides 
views of the site and the events that occur there in all four directions. The gallery exhibits the work of the flâneur-artist and other participatory street based conceptual art, like that of Elmaks and his Swap Box project.

\section{Street as Social Space}

Social space in the project comes way of both planned and unplanned spaces. In essence all the interstitial space between the programmatic elements is conceived as spontaneous social event space; however some planned social space occurs in the outdoor café, adjacent to the acoustic music stage and transit stop, but also in the rooftop park via the light well tables.

\section{Place of Solitary Contemplation}

Interpreted as a grid of trees which buffers the vibrant market from the quieter residential area along Holmwood Avenue, this space not only provides a practical function, but acts as a filter allowing one to distance themselves as much or as little as they wish from the busy theatre of the market. 

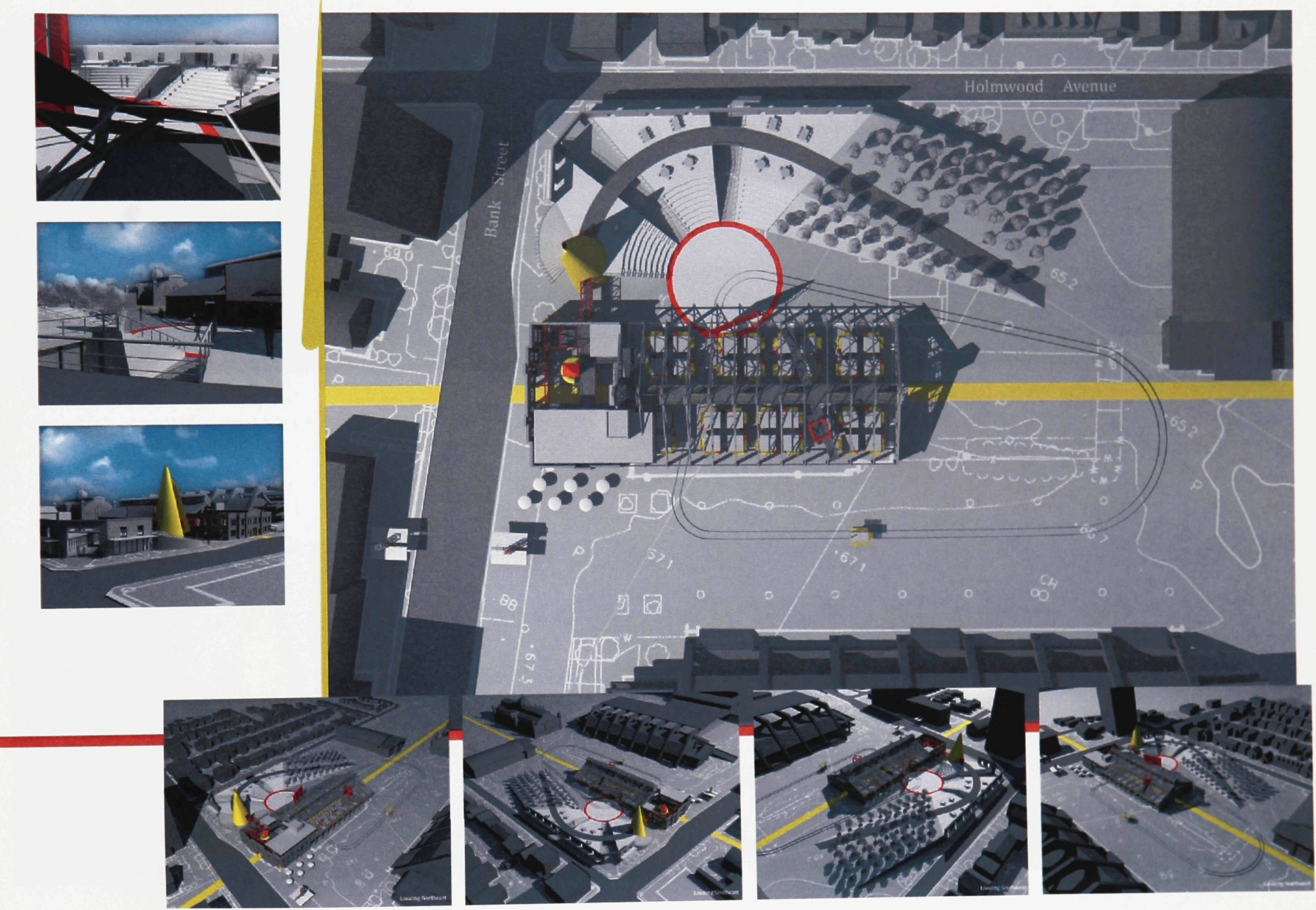


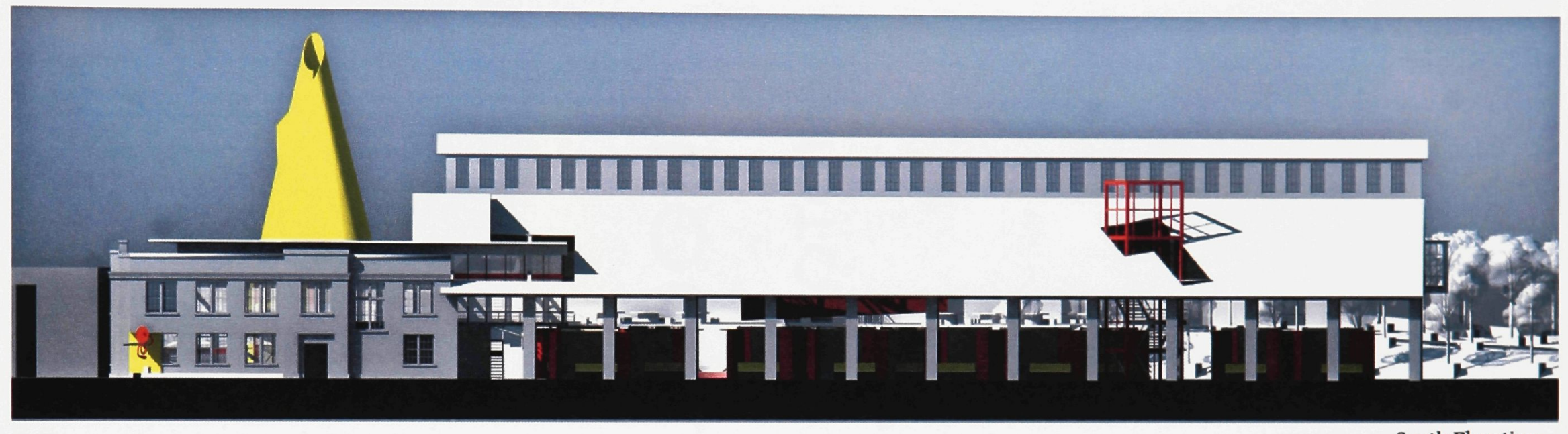

South Elevation

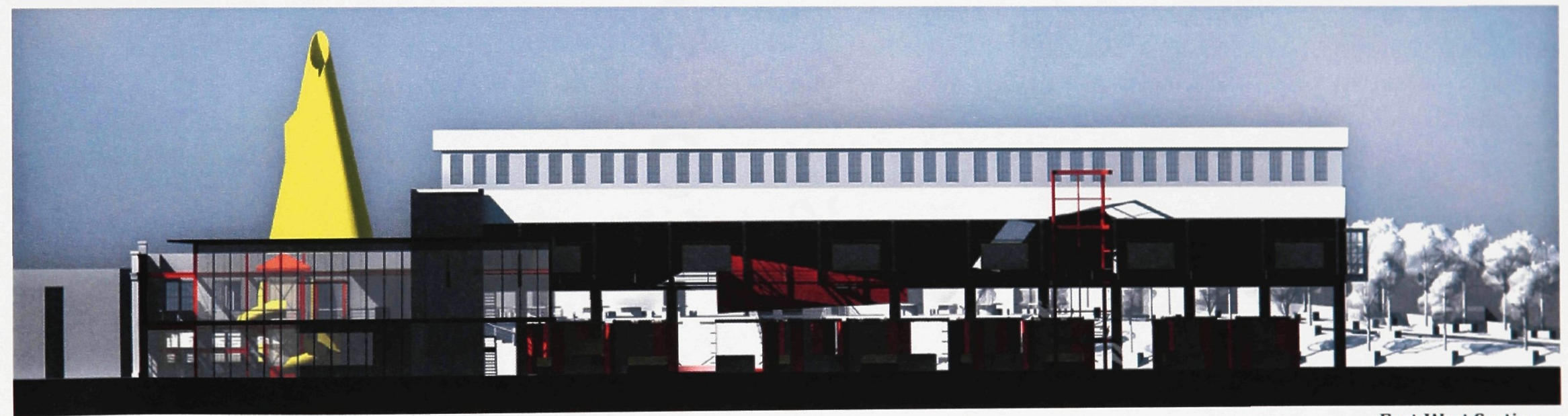




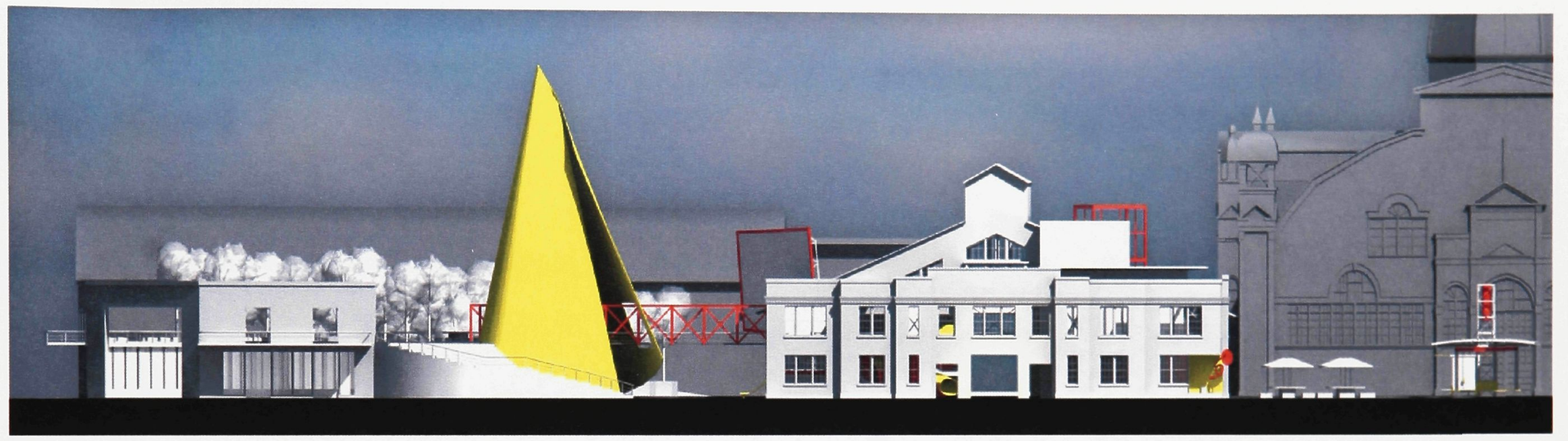

West Elevation [Bank Street]

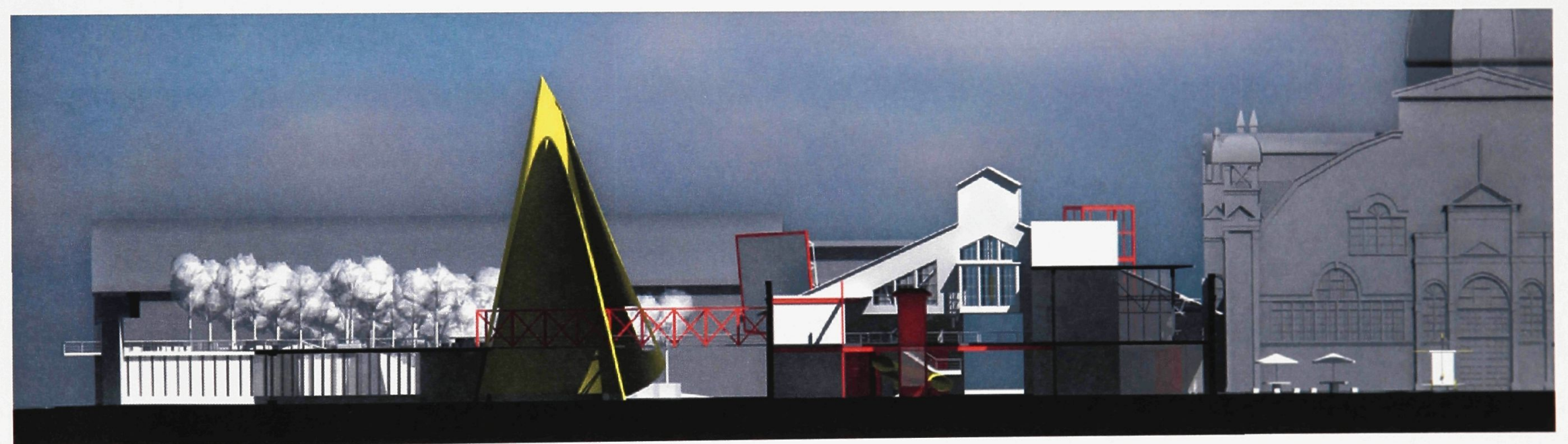

North-South Section 


\section{Bibliography}

Baudelaire, Charles. Paris Spleen. trans. Louis Varnese. New York: New Directions Publishing, 1970.

-. Selected Writings on Art and Artists. Trans. P.E. Chavet. Harmonsworth: Penguin, 1970.

-. The Painter of Modern Life. London: Phaidon Press, 1964.

Bauman, Zygmunt. "Desert Spectacular." ed. Tester, Keith. The Flaneur. London: Routledge, 1994. 138-157.

Benjamin, Walter. Charles Baudelaire: A Lyric Poet in the Era of High Capitalism. trans. Harry Zohn. London: Verso Publishing, 1983.

-. The Arcades Project. trans. Howard and Kevin McLaughlin Eiland. Cambridge: Belknap Press, 1999.

Brownstein, Charles. Eisner/Miller. Milwaukie,Oregon: Dark Horse Books, 2005

Buck-Morss, Susan. The Dialectics of Seeing: Walter Benjamin and the Arcades Project. Cambridge, Massachusetts: The MIT Press, 1991.

Buck-Morss, Susan. "The Flâneur, the Sandwichman, and the Whore: the Politics of Loitering." ed. Hanssen, Beatrice. Walter Benjamin and the Arcades Project. London: Coninuum International Publishing, 2006. 33-65.

Calvino, Italo. Invisible Cities. London: Random House, 1972.

Couch, N.C. Christopher and Stephen Weiner. The Will Eisner Companion: The Pioneering Spirit of the Father of the Graphic Novel. New York: DC Comics, 2004.

Doherty, Brigid. "'The Colportage Phenomenon of Space' and the place of Montage in the Arcades Project." ed. Hannsen, Beatrice. Walter Benjamin and the Arcades Project. London: Coninuum International Publishing, 2006. 157-183. 
Dunier, Mitchell. Sidewalk. New York: Farrar, Straus and Giroux, 1999.

Eisner, Will. New York: Life in the Big City. New York: W.W. Norton \& Company Ltd., 2006.

Elmaks. Deviant Art. 19 November 2007. 16 August 2008 <http://elmaks.deviantart.com/journal/>.

Jacobs, Jane. The Death and Life of Great American Cities. New York: Random House Publishing, 1993.

Jenks, Chris. "Visual Culture." ed. Chris, Jenks. Watching Your Step: the history and practice of the flaneur. London: Routledge, 1995. 142-160.

Leaning, John. The Story of the Glebe. Ottawa: M.O.M Printing, 1999.

LeCorbusier. Towards a New Architecture. Mineola: Dover Publications, 1986.

Lynch, Kevin. The Image of the City. Cambridge, Massachusetts: MIT Press, 1960.

Parkhurst Ferguson, Priscilla. "The Flâneur On and Off the Streets of Paris." ed. Tester, Keith. The Flâneur. London: Routledge, 1994. 2241.

Sheilds, Rob. "Fancy Footwork: Walter Benjamin's Notes on Flânerie." ed. Tester, Keith. The Flâneur. London: Routledge, $1994.61-80$.

Tester, Keith. "The Flâneur." Tester, Keith. The Flâneur. ed. Keith Tester. London: Routledge, 1994. 1-21. 